\title{
UC-NRLF
}

\section{PROVINCIAL MUSEUM}

\section{NATURAL HISTORY AND ETHNOLOGY.}

\section{VICTORIA, BRITISH COLUMBIA.}

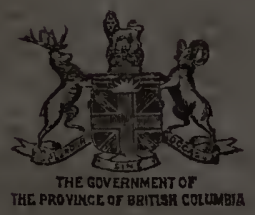

PRINTED BY

AUTHORITY OF THE LEGISLATIVE ASSEMBLY.

VICTORI.1, E. ( $\because$ :

Printed by Rı HAKD WuLFes Lex, I S.O., I.D., Printer to the King's Most Excellent Majesty. 1900. 


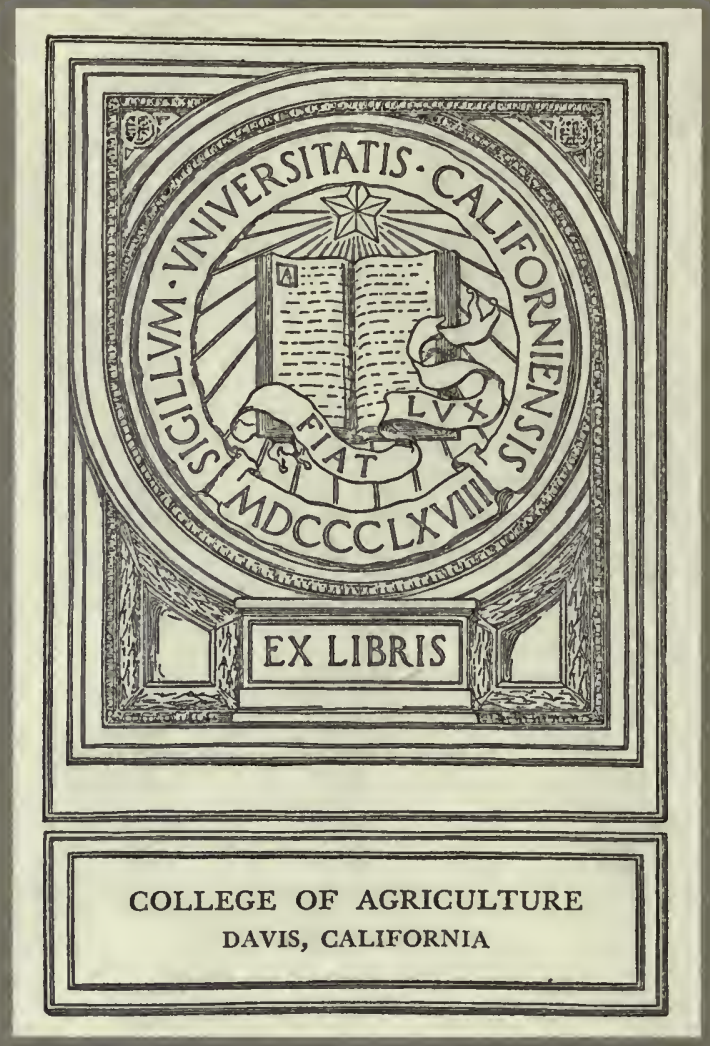


$-5$

(11.

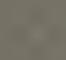





\section{Digitized by the Internet Archive in 2007 with funding from Microsoft Corporation}




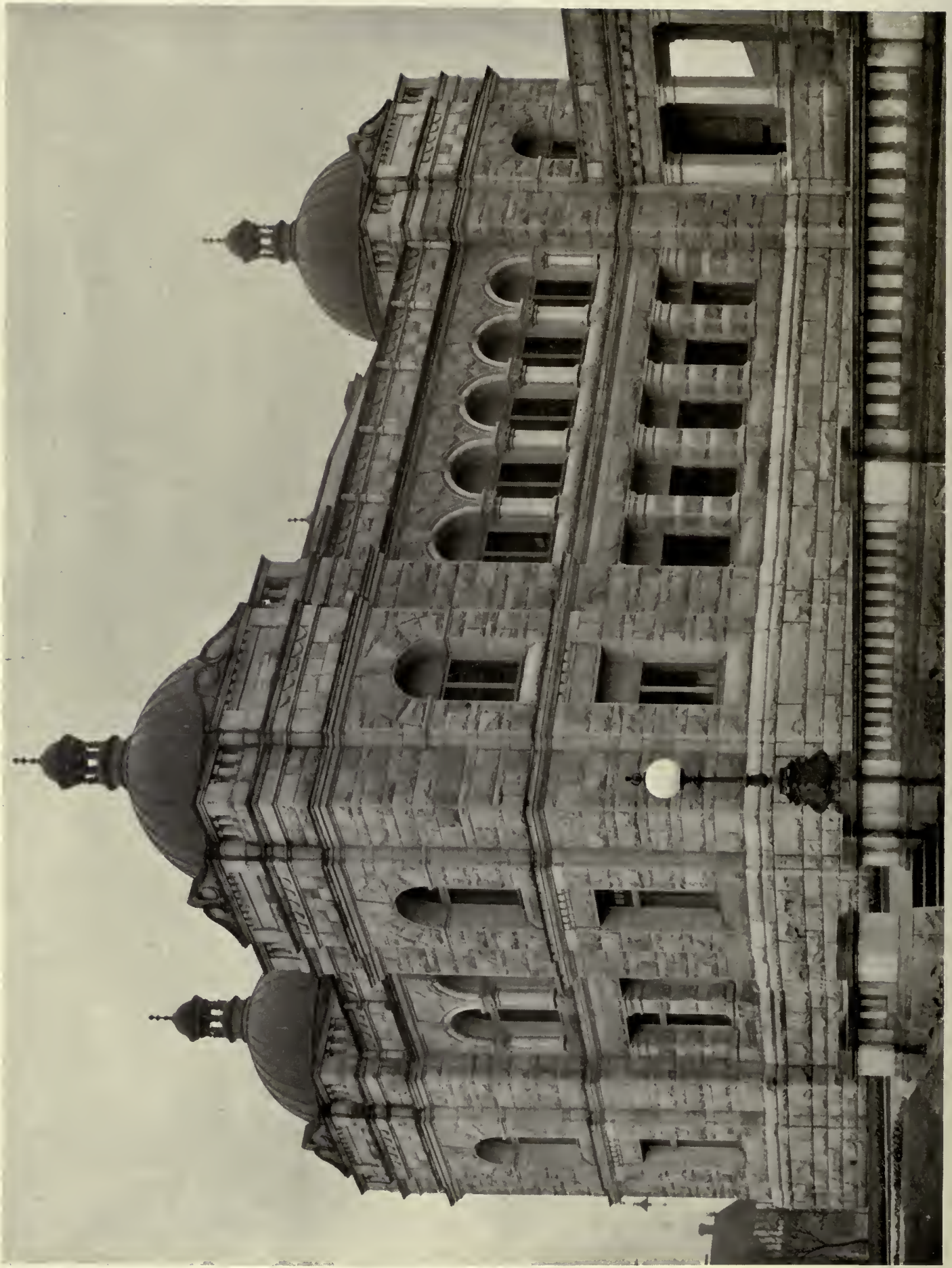




\section{PROVINCIAL MUSEUM}

$$
-\mathrm{OF}-
$$

\section{NATURAL HISTORY AND ETHNOLOGY.}

\section{VICTORIA, BRITISH COLUMBIA.}

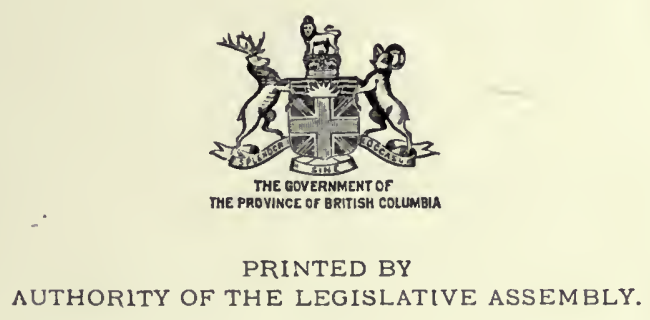

VICTORIA, B. C.:

Printerl by Richaro WoLfexnex, I.S.O., V.D., Printer to the King's Most Excellent Majesty 1909. 

The Honourable H. E. Young, M.D., LL.D.,

Provincial Secretary and Minister of Education,

Victoria, B.C.:

Sir,-I have the honour, pursuant to your instructions, to submit for your approval the following Visitors' Guide to the Natural History and Ethnological Collections in the Provincial Museum.

The economic importance of the knowledge concerning all forms of life is especially valuable in this Province, where the great bulk of our wealth is drawn directly from the hands of Nature, and there is reason to believe that the preparing of this Guide will greatly facilitate the study of animal life by our visitors, especially the young, whether pursuing systematic studies in Natural History and Ethnology, or from a desire to merely acquire casual information.

I have the honour to be,

Sir

Your obedient servant,

FRANCIS KERMODE,

Curator, Provincial Museum.

January 2Ist, Igog. 



\section{INTRODUCTION.}

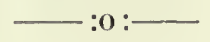

MLSEUM is an institution for the preservation of those objects which best illustrate Nature and the works of man, and the use of these for the increase of knowledge, and for the culture and enlightenment of the people; its special functions being to preserve and utilise objects of nature and works of art and industry. It supplies a need which is felt in every intelligent community and which cannot be supplied by any other agency; it does not exist except among highly enlightened peoples, and obtains its highest development only in great centres of civilisation, and is a necessity in every highly civilised community. The growth of a Musem from day to day may seem to be small, but the growth from year to year may be very large, so during the past it has often seemed as if little was being accomplished, whereas the last five years, taken as a whole, have been the most fruitful in the history of the Museum. During the last ten years the specimens in the Museum have, under the energies of the late John Fannin, and the present Curator, Frank Kermode, been practically renewed, while during the last five years many valuable additions have been made, notably: Fannin's Mountain Sheep (Ovis fannini, Hornaday): Stone's Mountain Sheep (Ovis stonci, Allen) ; and Kermode's White Bear (Ursus kermodei, Hornaday), captured in May, 1904, at Gribbel Island.

'The visitor', looking at the various animals and then at the labels, is almost lost in wonder at the immense distances from which the specimens were obtained, some possibly at great risk of danger to the life of the hunter, who has to be a sure shot, and have a keen eye and strong nerve to attack, for instance, a Grizzly Bear.

If in your travels you should visit Victoria, Vancouver Island, be sure you see the Provincial Museum. You will there see many strange and wonderful things, and if you have time to listen, stories will be told you, woven about these "Exhibits," that will make your 
visit a not-to-be-forgotten pleasure. Do you care for the glories of the chase? Go into the great hallway devoted to British Columbia's big game, and learn from the Curator the history of the GiantMoose, the Caribou and the Bear. Are you a lover of the weird and mysterious? The Indian legends told on the many totems here brought together would, if written down, fill a series of large volumes by themselves. Would you read from the fossils the history of successive periods since the world was young? The page is open to your gaze. Are you expert with the rod? If so, you will lye glad to hear the truly "big fish" stories the Curator can tell you. Care you to know the extent of British Columbia's mineral, or fishery or forest wealth? Ask questions and examine specimens.

It was on the 2nd of December, 1886 , that the Museum was formally opened up in a room 20x12, with no workshop attached. The Curator, Mr: John Fannin, was simply told that he must make the most of it until better quarters were provided, and for the first three years of the Museum's life nearly all the work was done at $\mathrm{Mr}$. Fannin's private rooms after the Musemm closed for the day. On the 24th of May, 1889, the Museum was removed to the Old supreme Court Building, and the work of loni'ding up the institution com menced in real earnest. Gradually, but surely, the development of the Musenm advanced until again the accommodation was totally inadequate. Then, in 1898 , it was moved to its present quarters in the eastern section of the Parliament Buildings; but it has outgrown these premises, and there should be erected now a building. twice as large and specially designed for Musem purposes; and until such a house is secured, the perfection of the collection must naturally be retarded.

The Provincial Museum (being essentially a British Columbia Museum) necessarily contains only those specimens obtained within its borders, hence none of them were procured by exchange with other parts of the Continent, so that the value of a collection so truly local in its formation is incalculable.

The collection is wortly of a large building, and is a credit not only to the Govermment under whose direction it is managed, but to the people of the Province, whose individual efforts have done so much to assist its growth in the way of contributions, as very many specimens now in the Museum have been presented by friends to the institution from every portion of the Province. 


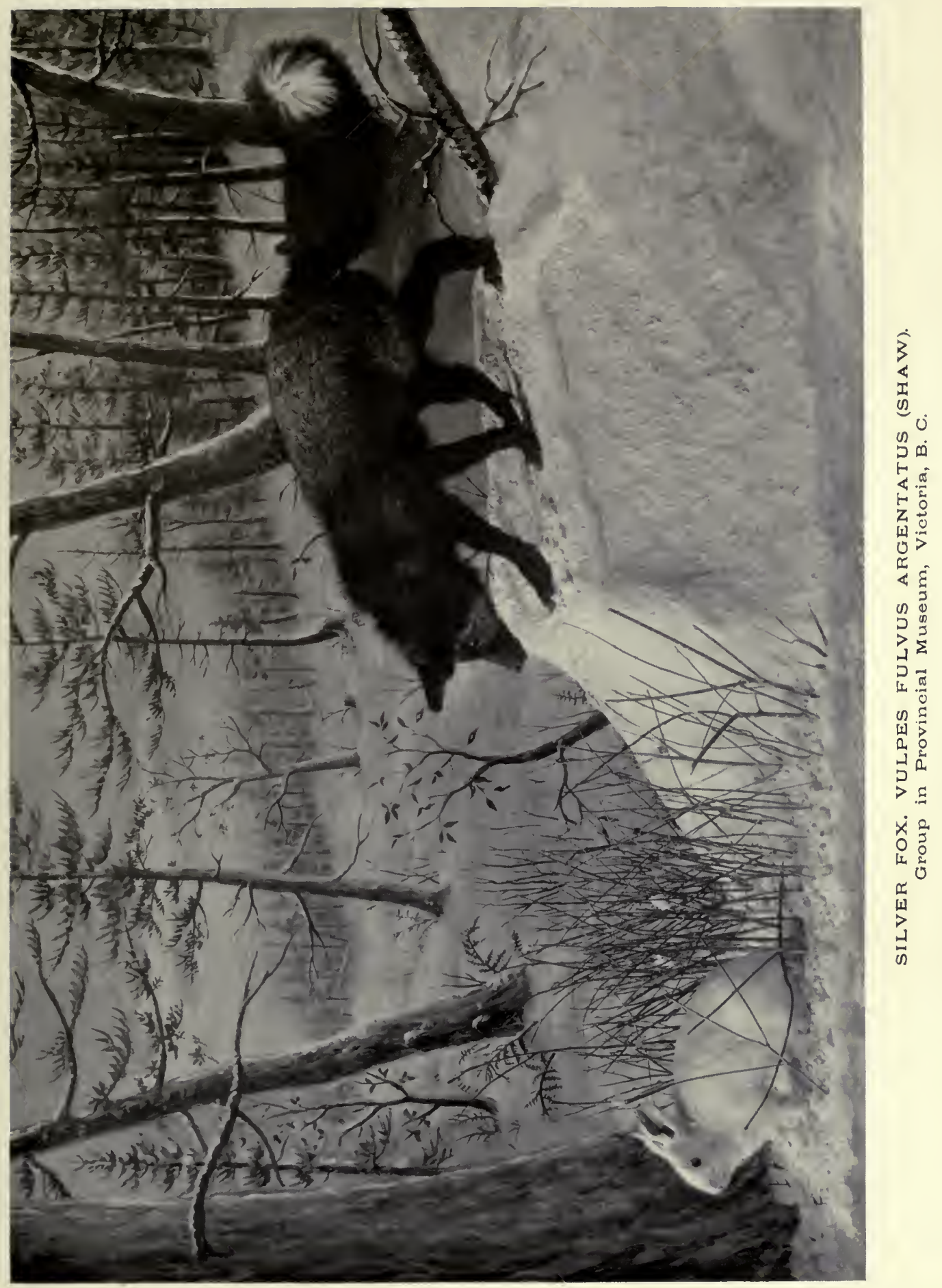



The Ethnological Collection contains over fifteen hundred specimens of the skill of the natives of this Province, and illustrates the common life of them from a remote past, the age of which we have no means of ascertaining, up to the introduction of European manufactures and implements, and the consequent disappearance of the older arts. The advent of iron. steel and lorass appears to date from about one hundred years ago or even earlier, and was probably followed for some time by an inporement in wood carving, such as may be expected from the use of sharper tools. This collection is another department where much requires to be done, and that quickly. Every day increases the difficulty and cost of procuring relics of the fast disappearing original occupants of the land, where legends told of many toten poles are as curious and deeply interesting as any histolies of bygone nations can be. 'Though in the midst of a collection area univalled in the world, little is heing done, or has been, to take advantage of the golden opportunity of the present. The collection, although incomplete, is at the same time a most interesting study, embracing as it does some relics of almost every known Indian tribe of British Columbia, either extinct or still existing. The jade implements are especially deserving of attention, as well as one piece of jade weighing upwards of twenty-five pounds, no doubt the largest specimen ever found on the Pacific Coast.

The grouping of mammals and birds, which is now the principal feature in all Museums, has been initiated here, and groms shown with their natural surroundings, at a glance teach a person as to their habits and life history. The Musemm contains good collections, embracing, as it does, many fine and rare specimens.

The Ornithological, or Bird Collection, too, is admirable and complete, not only erery lamilial feathered friend leing met with, but specimens being on view of birds entirely new to British Columbia, if not to the Pacific Coast; and the Musem Collection intelligently read offer's incontrovertible evidence of the constantly changing distribution of the birds of the world.

The fishes of the Province are fairly well represented, both in alcololic specinens and gelatine casts. the latter method being now almost entirely employed in representing the fishes, and so far with satisfactory results. The fish of British Columbia waters offer a very varied list of specimens from the Smelt (Osmerus thaleiehthys, Ayres) to the Halibut (Hippoglossus vulgaris, Fleming). Here we 
have a Tyhee or Spring Salmon (Oncorhynchus tschavytscha, Walbaum), weighing seventy pounds, caught in Campbell River with rod and line. Then there is the Kamloops Trout (Salmo gairdncri kamloops, Jordan), a truly fine, big fish. Then we have the Hand-saw fish (Alepisaurus borcalis, Gill), a peculiar long and narrow fish; also the Oolachan or Candle fish (Thalcichthys pacificus, Richardson). This fish is so naturally oily that when dried it is used as a candle by the Indians. This is followed by an immense White Sea Bass ( Cynoscion nobilis, Ayres) ; then comes the Ribbon fish (Eques lanceslatus, Linnaeus). This fisl was caught in fish traps at Sherringham Point in 1907. It is an interesting fish of a beautiful and singular colouration, resembling that of a chatodont and is some six feet in length; also the Californian Bonito (Sarda chilensis, Cuvier and Valenc.), taken at Rivers Inlet, B.C.; then the Chub Mackere! (Scomber colias, Gmelin). This is the Spanish Mackerel of England, is widely distributed north to England, Maine and San Francisco. very common in the Mediterranean and in Southern California, smaller than the common mackerel and inferior to it, although a food-fish of importance; then the California Barracuda (sphyrana argcnter, Gaird), a long and slender fish, an important food-fish with flesh rich, firm and delicate-a sonthern fish. Next comes the Prow fish (Zaprora silcuus, Jordan); this is the type, there having been two caught and both of them in onr waters. These are the only two known, a very curions fish indeed. In fact we might go on enumerating the different species that are to be obtained in $\mathrm{onr}^{\circ}$ waters indefinitely.

The Crustacea Collection contains most of the larger species of British Columbia. Some of the crabs are grotesquely ornamented witl spines and knobs, and others, when alive, were even more strongly decorated with sea-weeds and zoophytes to conceal them from their enemies. The "stone" crabs are especially well represented, including the large so-called "king" crab and small "turtle" crab, which is so hidden by its shell that none of its legs are visible from above when it withdraws them. Many of the small Crustacea have yet to be collected. Star fish and sea nrchins are well represented in the collection which also contains some exceedingly rare and remarkable specimens.

Of Sea-weeds or Marine Algae there are about one liundred specimens; also some sponges. 


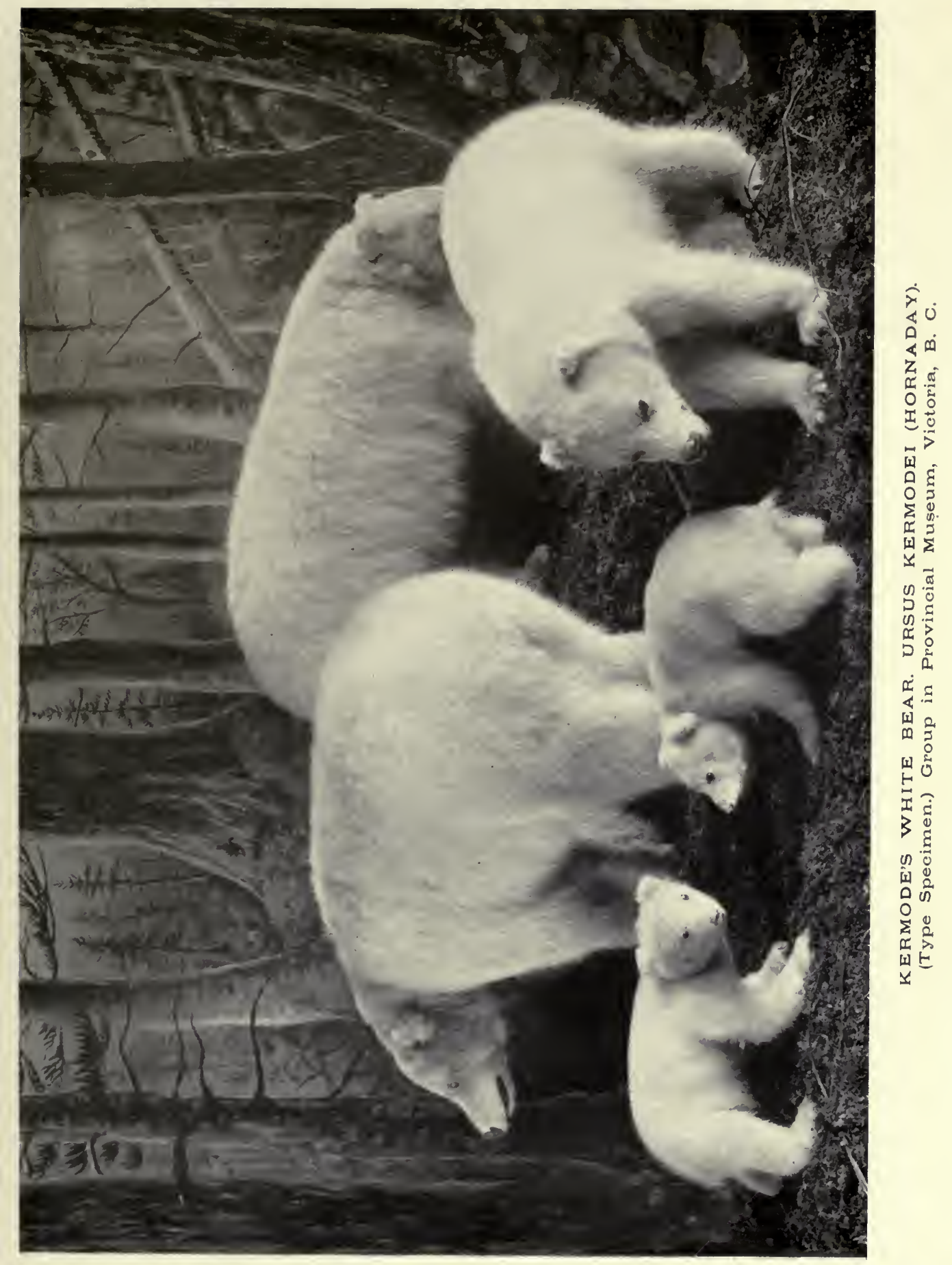



Although the Shell Collection is a fine one, the Musem is in lack of land and fresh water species from tle whole Province.

It must be prenised that the collection of fossils is in its infancy; the first glance will slow the truth of sir A. Geikie's statentent, that marine mollusea form the alphabet of Palacontology, the seience treating of the forms of animal life in the rocks of the earth's crust. The first animal remains to be mentioned, howerer, helong to the vertebrates, and are believed to have lived during the existence of the Glacial period of our history. Then we have also several mammoth teeth, mostly fomd in the Province, and almost without doubt belonging to the hairy mammoth. Marine shells of the ice age are shown from Comox, Sucia Islands and Victoria. The Pliocene system, or the most recent tertiary, is represented by a small collection from sea cliffs near Sooke. Near these shells is a formation containing brown or soft coal, the layers exposed on the beach being mostly water-worn logs perforated by teredo. To the Miocene period belongs the collection of fossil shells from Carmanal loint, at the entrance to the Strats of Fuca. The specinens are, with few exceptions, identical with those found in rocks of similar character at Astoria, on the Columbia River. The Cretaceous period containing the productive coal measures of Vanconver 1sland and the Queen Charlotte Islands is not marked off from the Eocene tertiary by any great break. The plant remains are essentially similar, and the trees which flomrished at the same time as the regetation forming the coal we now use as fuel, belonged to such recent orders as the joplar, birch, elın, oak and willow, together. with a palm (Sabalim. perialis) and several ferms. Nanaimo, Comox, Sucia, Hornby Islands, Cumshewa and Skidegate are the richest and most accessible localities for fossils of this time and there are here numerous species from each place. According to the ordinary classification the Secondary Age may now be left for the Primary or Palacozoic. Rocks of this age have been distinguished by means of their fossils at various places on Vancouver Island and Mainland. It is supposed that the hard erystalline diorites and limestone of Vanconver Island, and the Coast Range of the Mainland, are composed of materials belonging to the carboniferous system, as fossils lave been found at Horne Lake and the Ballinac Islands, indicating this to be the fact. The Cambrian period is represented by fossils from Mount Steplien in the Rocky Mountains. At this place exists one of the most interesting assemblages of organisms yet found in the Province, 
for excepting some obscure organic remains obtained from earlier strata, they are the earliest forms of life yet discovered in the world's history.

The Entomological collection is both valuable and instructive. Here you will find types of many species discovered on Vanconver Island and the Mainland; and the butterflies, moths and heetles form a very inspiring sight, arranged, as they are, scientifically according to classification.

At the taxidermists laboratory many mammals and birds were finished last year, including some fine groups in cases. 


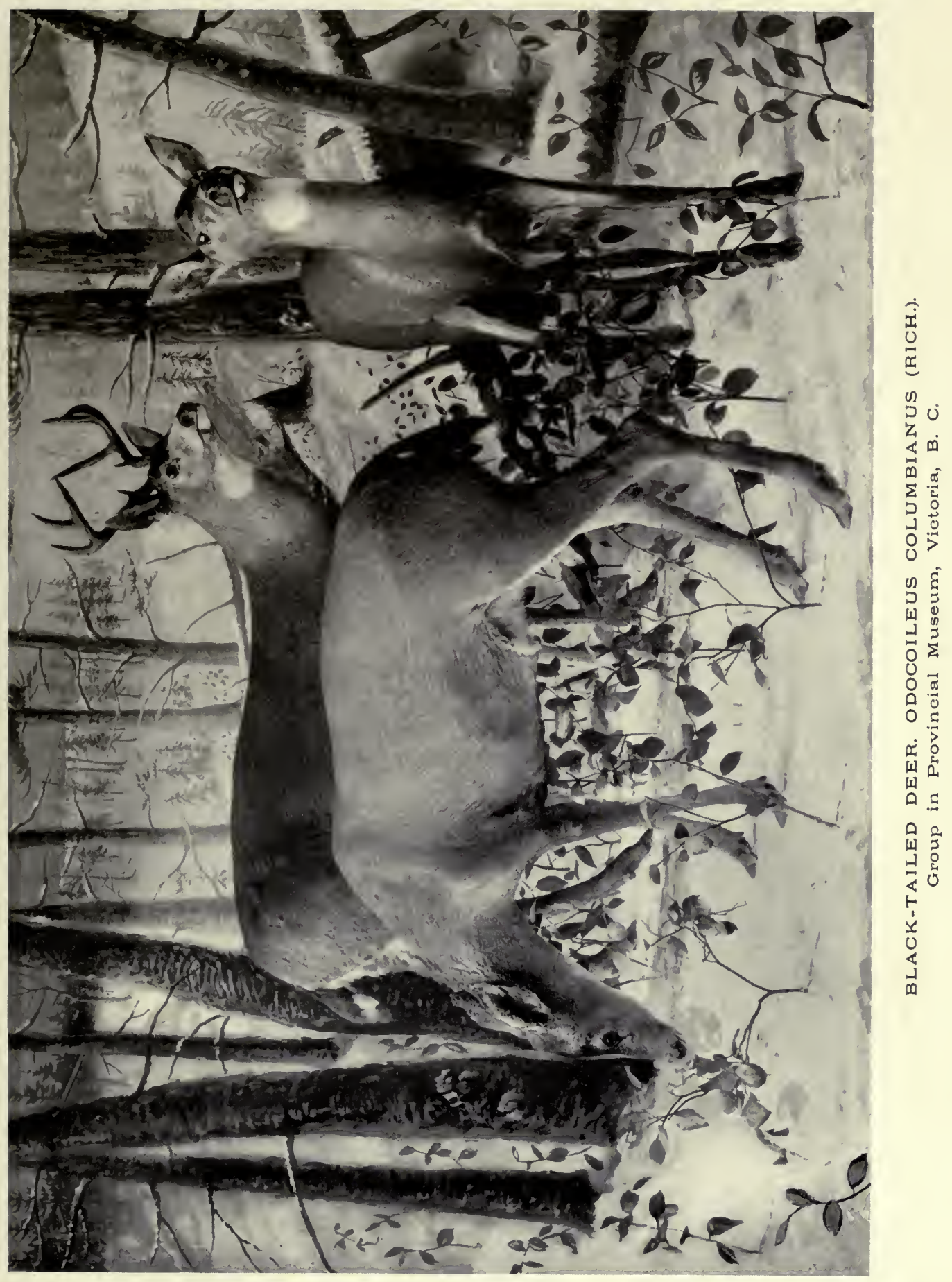





\section{ENTRANCE HALL.}

Here we find three Indian totem or heraldic poles. The one on the right of door as you enter is the giant cedar (Thuja gigantea), carved and painted in red and black. Of the three figures represented the upper and principal one is a raven. The middle of the pole was cut away below to provide a doorway for the house in front of which it stood. This is from Bella Bella.

The next on the right is a totem pole nade of giant cedar, carved and painted to represent various figures. This formeriy stood at the back of "The house which chiefs peep at from concealment" (feeling their inferiority), at Skidegate, Queen Charlotte Islands. It belonged to the chief " 'Though younger brother must be obeyed," of the "Rotten House" division of the Eagles of Skidegate, and shows some of his principal crests. The upper figure is a raven with two frogs lianging from its moutl, and below it is the mythical mountain lıawk.

The pole faced the door of the house in front of which, outside, stood the high pole which showed not only the crest of the chief, but also his wife's. At the top are three small male figures wearing high-crowned hats, then comes the raven with dog-fish below it, both eagle crests; and at the bottom is a killer-whale which belonged to the wife, who was of the raven division.

Then following around the wall, in the next corner, is a heraldic house pole, which formerly stood at the back of "The house so large that people must shout to make themselves heard in it."

This belonged to Chief Nestakana, of the "Great House" division of the Eagles of Skidegate, Queen Charlotte Islands, and shows two of his crests.

The upper figure is the raven with its beak broken and bent down, as told in one of the stories of its adventures; and below is a whale. The smaller figmes are used to fill up space ornamentally.

On the high pole at the entrance are also shown two of the chief's crests; the raven above and the dog-fish next. At the bottom is a grizzly bear, a crest of his wife who belonged to the principal raven family of Skedans. 


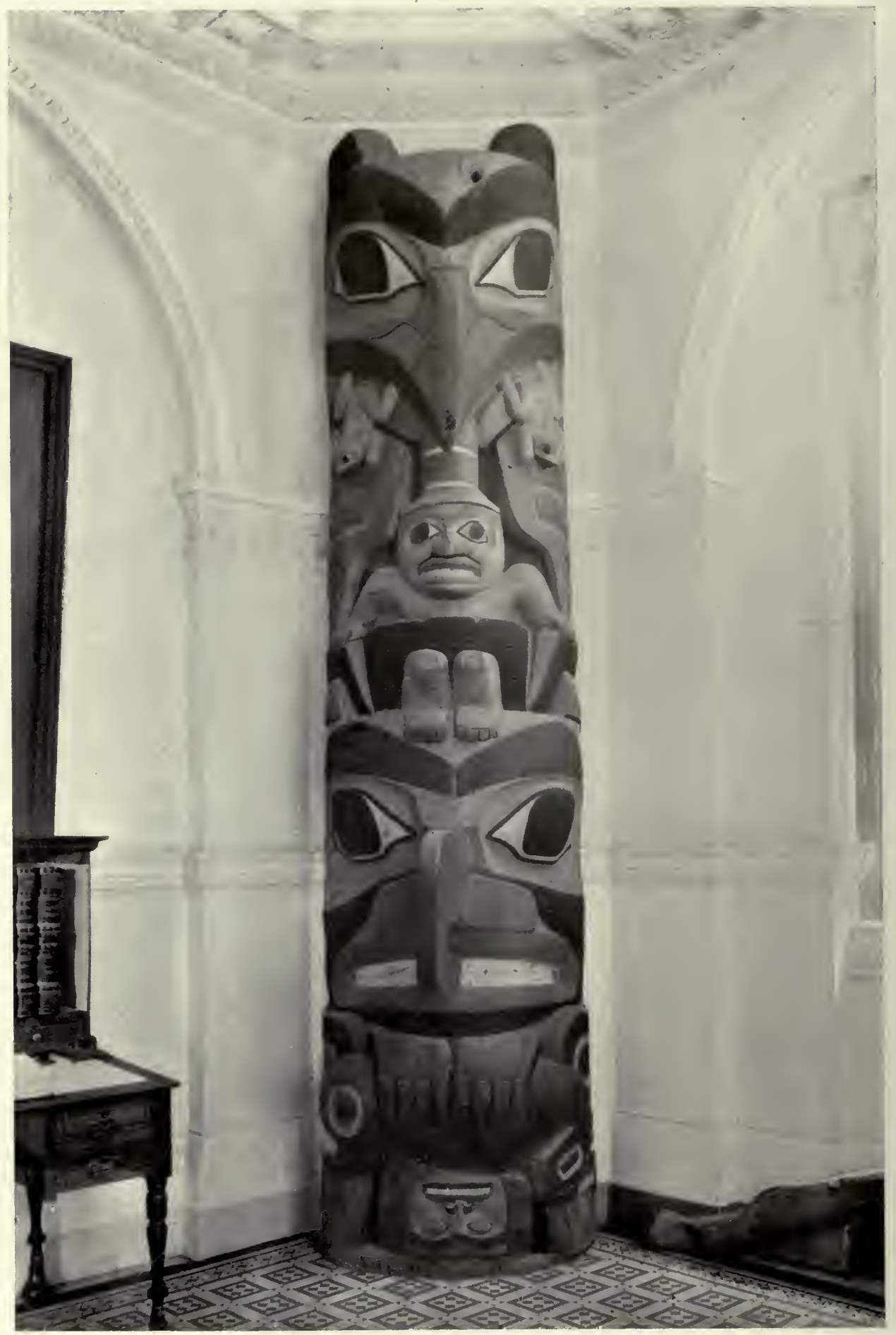

HERALDIC OR TOTEM POLE (No. 1). 


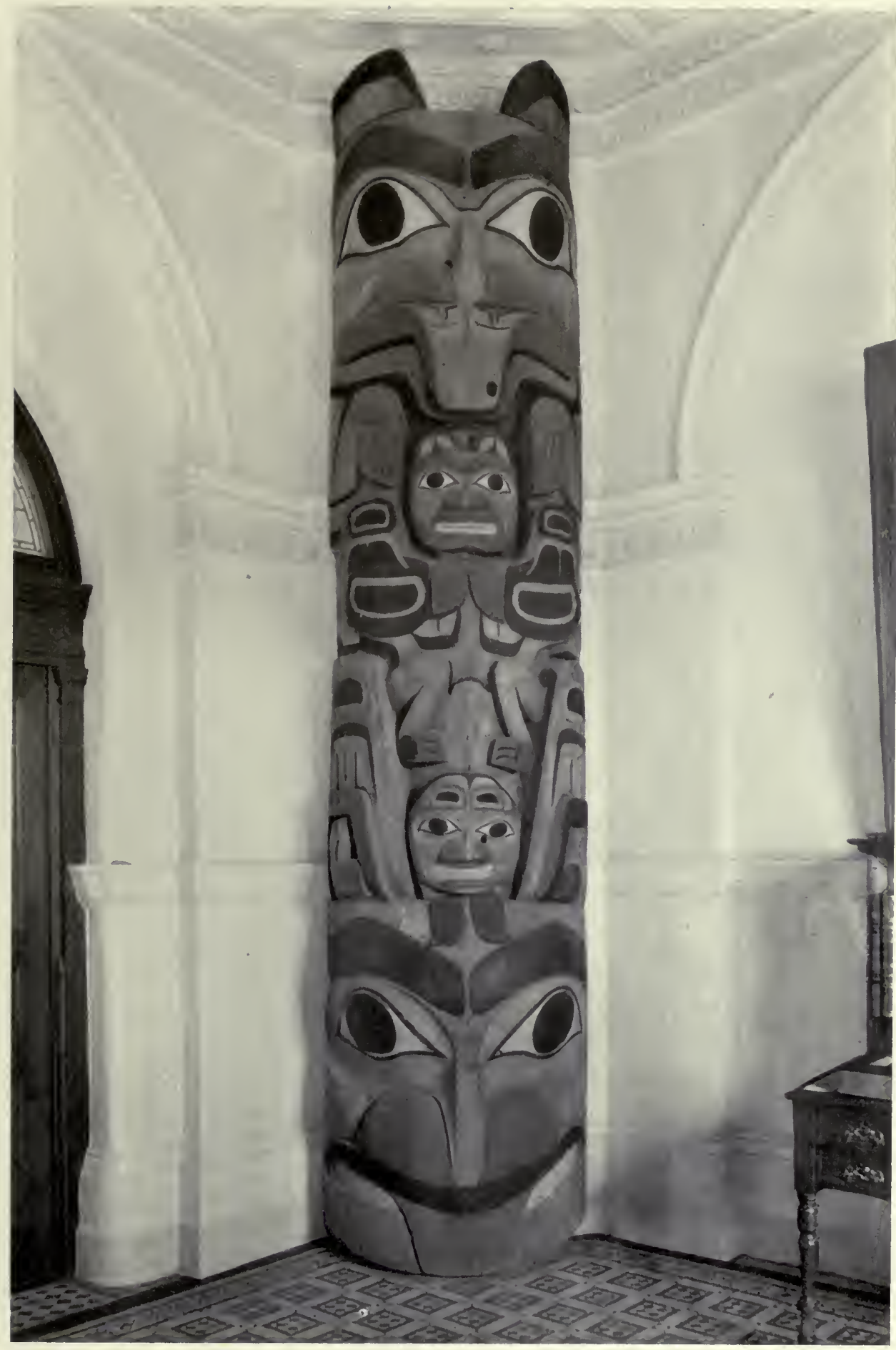

HERALDIC OR TOTEM POLE (No. 2) 
The next is the fignre of the man who first brought copper to the Indians. The man is standing with a piece of copper. painted in a totemic design, in his arms. He is wearing a chief's hat with two extra crowns. This is also made of giant cedar and is from Bella Bella.

There are three or four raven masks, with movable jaws, used in dancing. They are also from Bella Bella. 


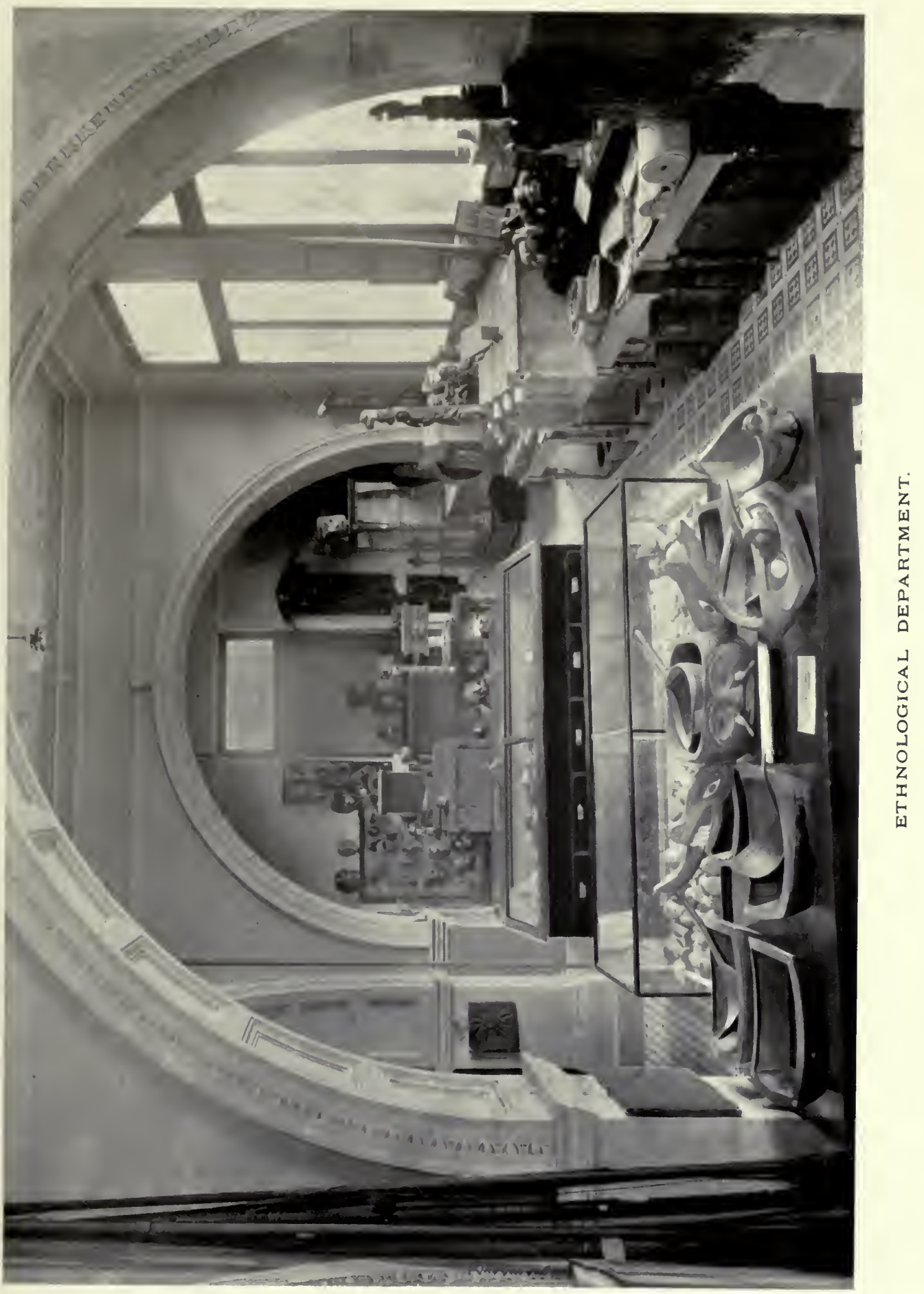




\section{MAMMALS.}

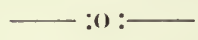

Entering the Musem on the left are seen various kinds of deer.

Moose (Alee gigas, Miller).

Of all the big animals of the North, the "Giant" Moose appeals most strongly to the imagination of everybody in general, and to the sportsman in particular. It is truly the colossus of the North.

American Elk "Wapiti" (Cervus canadensis, Erxleben).

Look at its majestic head, crowned by a pair of mighty antlers : This animal is distributed over the south-eastern portion of the Mainland, the West Coast of Vancouver Island, in the Comox District, and to the Northward.

\section{Mountain Caribou (Rangifer montanus, Thompson-Seton).}

Found in the Algach Mountains and White Cap Mountains; a grand bull, and its cow and calf. They range throughout the entire Mainland, from the Southern to Northern Boundary.

Osborn's Caribou (Rangifer csbormi, Allen).

Found in the Atlin District, and leadquarters of the Stikine River.

\section{Queen Charlotte Caribou (Rangifer dawsoni, Thompson-Seton).}

Found at Virago Sound, Graham Island, of the Queen Charlotte Islands. Caribou, in a state of nature, live on "Reindeer moss," tree-moss, and lichens, and they love ice-covered lakes and ponds as much as any boy. Their loose-jointed and widespreading hoofs and enormously developed "dew-claws" have been specially designed by Nature to enable these animals to run freely, as if on snow-shoes, over snow which to any small-hoofed deer would be quite impossible. 



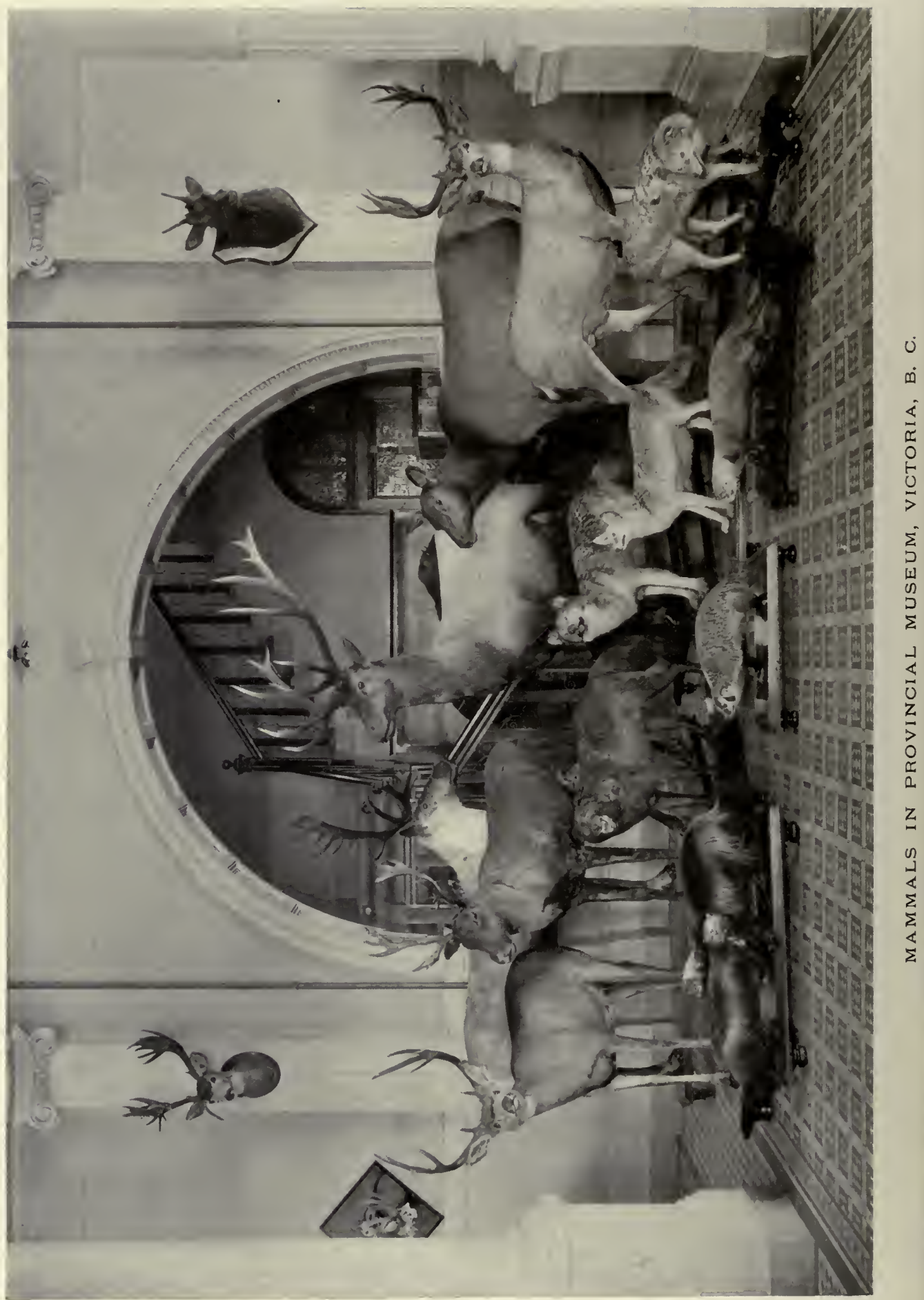




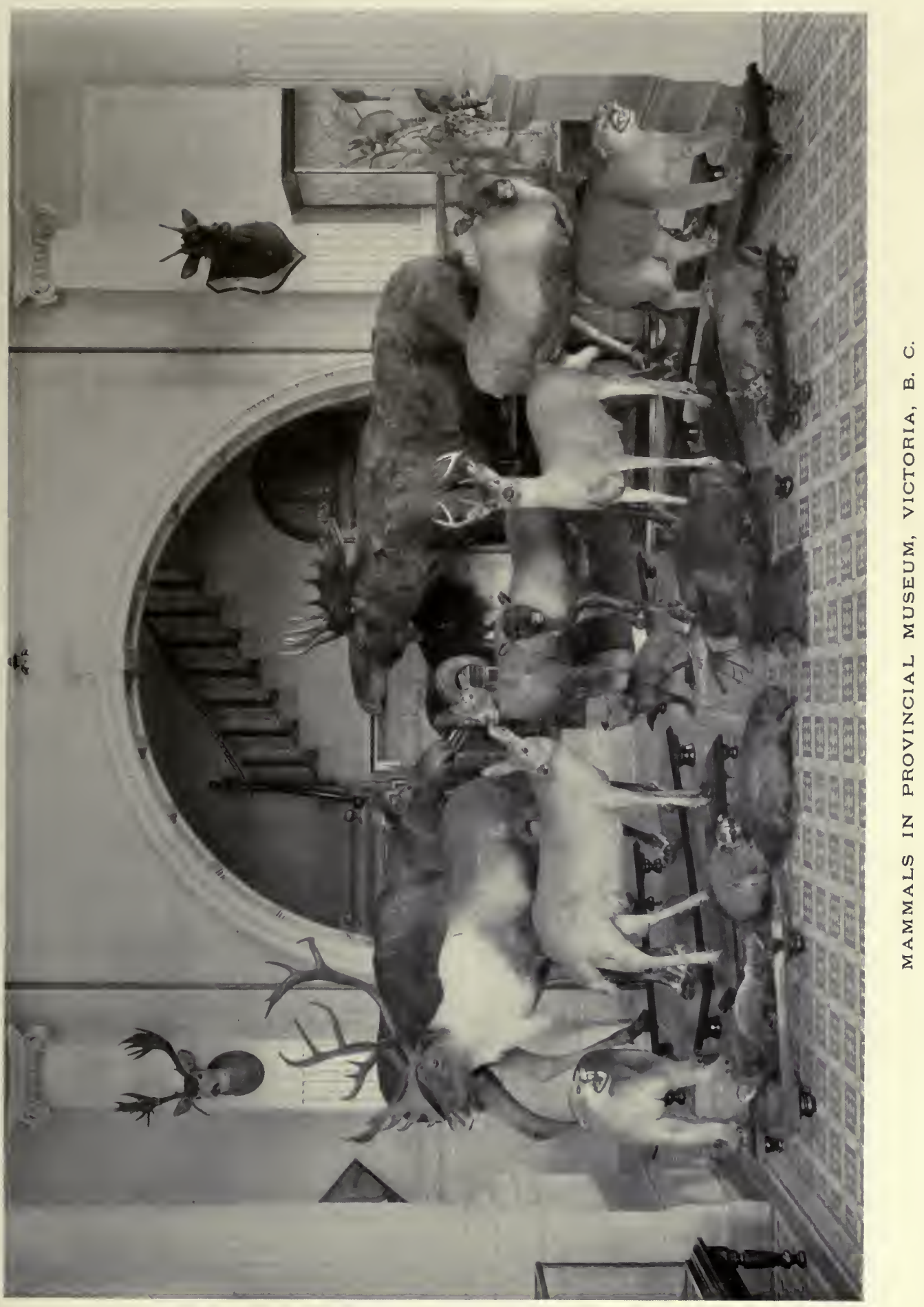



Mule Deer (Odocoileus hemionus, Refinesque).

This fine animal is universally known throughout the Rocky Mountain region, which constitutes its home. In Manitoba this animal is called the "Jumping Deer," because, when rumning at a gallop, it makes a series of stitf-legged jumps or "bucks" of great length. To anyone who sees this gait for the first time it is quite astonishing. When it dashes ont of a clump of stunted cedars, and goes flying down the erest of a bare ridge, it bounds past in full view for a quarter of a mile, reaching out with its fore-feet, but for each leap its springs into the air with stifiened legs and goes bounding forward as if the ground were an indiarubber cushion that throws it upward and forward every time it touches it with its feet. In reality its knees do bend a trifle just as its feet touch, to lift his body upward again, while its strong hind-legs thrust it forward.

Having now reached the end of the mammals on the left we cross over to the right, and here we find a case containing a group of

\section{Black-tailed Deer (Odocoileus columbianus),}

in a snow-scene with a painted background. These specimens were obtained at Englishman's River, Vanconver Island, B.C., November, 1907. They lange west of Cascades from Washington to Alaska, including all the larger islands except the Queen Charlotte Group.

\section{White-tailed Deer (Odocoileus virginianus).}

It ranges through the southern portion of the Province, east of the Cascade Mountains.

American Panther (Felis concolor, Linn).

Known also by the following names:-Cougar, California Lion, Puma and Mountain Lion. They are common on Vancouver Island and lower portion of the Mainland.

Bank Beaver (Aplodontia rufa, Rafin).

It ranges east of Cacsades, west along the Fraser to Chilliwhack.

Beaver (Castor fiber, Linn).

Range: The greater portion of the Mainland and Island. 
Western Porcupine (Erethizon epixanthus, Brandt).

It ranges the Mainland at large.

Then follows a case of small mammals, among which we find Minks, Skunks, Moles, Rats, Mice and Bats, ete., truly a heterogeneous lot. Among then will be seen the Jumping Mouse (Zapus trinotatus).

Raccoons (Procyon lotor, Linn).

These animals are somwhat clumsy and deliberate in their movements as compared with the majority of the wood-dwellers. Their thick fur enables them, like the bears, to rifle bee-trees in comparative safety, and to dig bumble-bees and hornets ont of the turf. They are here shown feeding in a wild crab-apple tree.

White Goat, or Antelope Goat (Oreamnos montanus, Ord),

It is found on nearly all the mountains of the Mainland, its abundance centreing along the summit of the Coast Range.

Dall's Mountain Sheep (Ovis dallii, Nelson), ram and ewe.

These were obtained at Cook's Inlet; its range is North-West British Columbia and Alaska. Then follows type specimen of

Fannin's Mountain Sheep (Ovis fanninii, Hornaday).

This fine sheep was taken near Dawson City, North-West Territories, and ranges through into the Atlin District, B.C. The next case contains a pair of

Black Bears (Ursus americanus, Pallas),

Taken at Sooke, Vanconver Island, and Bridge River. It ranges thronghout the whole of British Columbia, and is to be found very plentiful in the fall of the year along the banks of the rivers feeding on salmon that die by the thousands after spawning or on the way to the spawning ground. These are followed by the

Queen Charlotte Black Bear (Ursus carlotte, Osgood).

It is from Skidegate, Queen Charlotte Islands.

\section{Kermode's White Bear (Ursus kermodei, Hornaday).}

This new type specimen was captured at Gribbel Island, B.C., in May, 1904, and now the species is represented by a group of five specimens. Then passing up the next aisle, to the right, we find a case of 


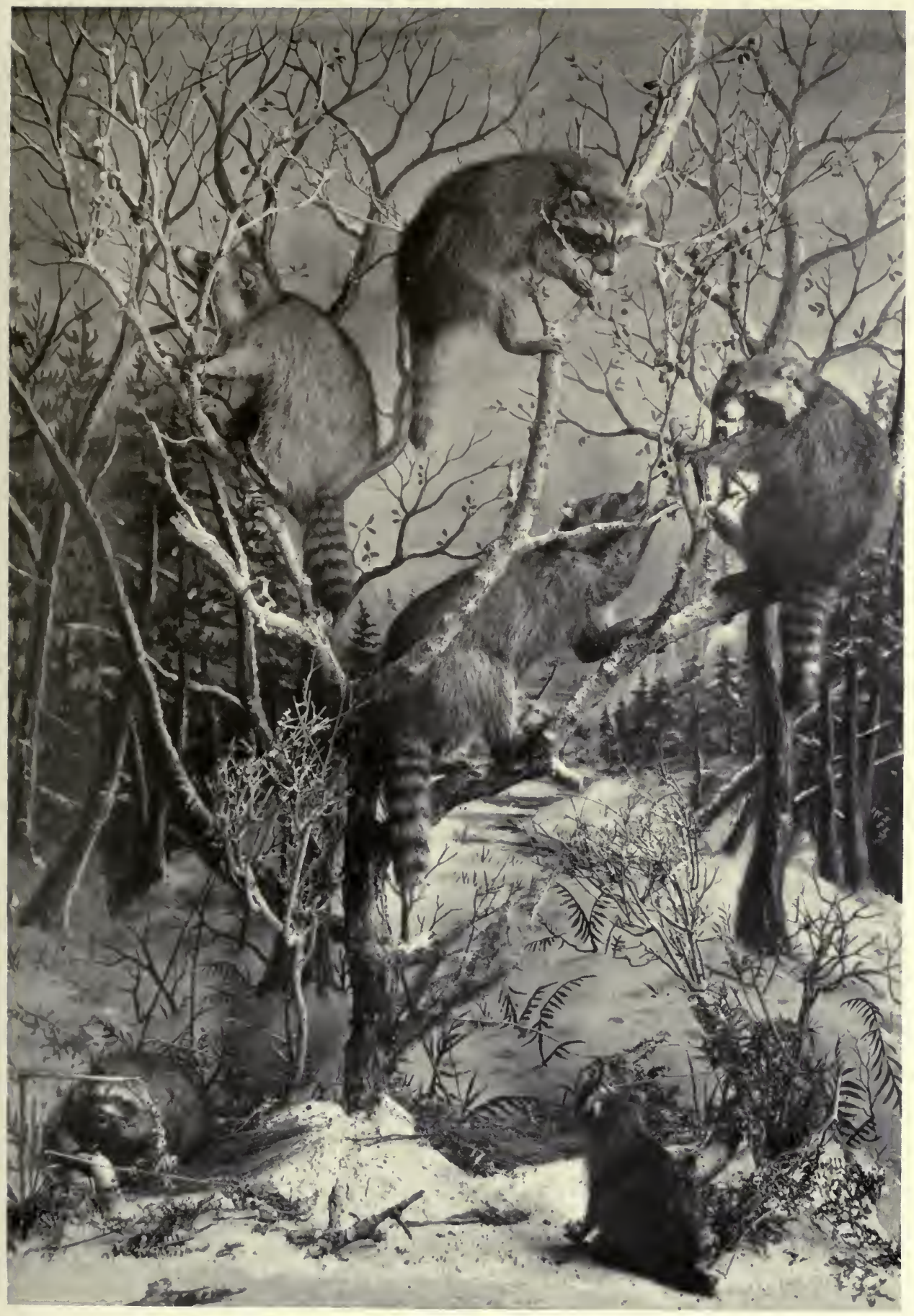

RACCOON. PROCYON LOTOR (LINN.)

Group in Provincial Museum, Victoria, B. C 

Hoary Marmots (Arctomys caligatus, Esch).

Taken at Lillooet, B.C. They range Vaucouver Island and Mainland.

Coyote, Prairie Wolf (Canis latrans, Say).

To be found on the Mainland, east of Cascades. Next we come to a case containing a model of a

Killer Whale (Orca pacifica).

It is a young one, and was taken from its mother, which was found drifting near Trial Island.

Bay Porpoise (Phocena vomarina, Gill).

Taken in the Straits of Georgia. Then comes a case containing a group of

Stone's Mountain Sheep (Ovis stonei, Allen), ram, ewe and lamb.

They were taken at the head-waters of the Iskoot River, B.C., in 1905. Turning to the right here, and following down on the left, we have a case containing a fine group of

Big-horn Mountain Sheep (Ovis canadensis, Shaw), male and female, with two lambs.

These range the mountains of the Mainland, except the Coast Range, from Kootenay to Cassiar, and have been taken at Cassiar, Similkameen, Bridge River and Chilcotin. These are followed by a

Raccoon (Procyon lotor, Linn).

Ranges the coast line of the Province.

American Badger (Taxidea americana, Zimm).

Taken at Okanagan.

Mink (Lutreola vison, Briss).

Ranges the Island and Mainland, east and west of Cascades.

Sea Lion (Eumetopias stclleri, Less),

Taken in a salmon trap, near Point Roberts, B. C., September 1897. This animal ranges from the southern coast of Vanconver Island to Alasaka. 
Hair Seal (Phoca vitulina, Linn).

Group taken at Ǩhutze Inlet.

Fur Seal (Callorhinus ursinus, Linn). Group.

These valuable fur-bearing animals migrate in great numbers along our Pacific border to Alaska.

Land Otter (Lutra canadensis).

Range: The Island and Mainland, east and west of Cascades.

Pacific Walrus (Odobanus obesus, Allen),

Comes from Icy Cape, Alaska.

Grizzly Bear (Ursus horribilis, Ord),

Taken at Revelstoke, B.C., and which ranges over the whole of the Mainland from the Coast to the Rocky Mountains.

Grey Wolf (Canis occidentalis, DeKay).

Found at Sooke, Vancouver Island, and common throughout the whole Province.

Dusky Wolf (Canis occidcutalis, DeKay var nubilus).

Taken at Clinton, B.C.

Then comes a case with a Silver Fox just about to jump on to a rabbit. On the other side of the stairs is a fine

Musk Ox (Ovibos moschatus, '/imm).

Found in the barren grounds of Northern Canada.

Common Lynx (Lynx canadcusis, Ker'r).

Taken at Grand Prairie, B.C. Ranges over the Mainland at large.

Bailey's Lynx (Lynx bailcyi),

Ranges the southern portion of the Mainland, east of the Cascade Range.

Wild Cat (Lynx rufa).

Ranges the Mainland, west of the Cascades. 
Upstairs we have the Ornithological Collection. In the first case there is the

\section{ORder PYGOPODES. D Diving Birds.}

\section{Fanily PODICIPEDIDA. Grebes.}

Acirmophorus. (Cones).

Western Grebe (Xchmophorus occidentulis, Lawr).

This is a remarkable Grebe, the largest of this country, and one requiring comparison with no other for its determination. It is a fine-looking bird on the water, has a trim and shapely aspect, like a clipper-ship. They are not shy, and have great power of diving. It is an abundant resident throughout the Province, and a winter resident along the Coast, where in some localities, such as Howe Sound and Burrard Inlet, it appears in great numbers. We have four other Grebes in British Columbia, they are the

\section{Colymuss. (Linnæus).}

American Red-necked Grebe, Holboell's Grebe (Colymbus holbœlli, Reinh).

A common winter resident along the coast of Vancouver Island and Mainland. Winter resident on Okanagan Lake.

Horned Grebe (Colymbus auritus, Linn).

A common winter resident on the Coast, and very common in the Straits, near Victoria, in April. Breeds on the lakes from Okanagan to Dease Lake.

*American Eared Grebe (Colymbus nigricollis californicus, Heerm).

Taken at Kamloops. Found breeding on lakes at Kamloops.

I'odluymbes. (Lesson).

Pied-billed Grebe (Podilymbus podiceps, Linn).

Common resident on Vanconver Island and Mainland. It breeds on lakes close to Victoria and throughout B.C. generally.

Family GAVIIDA. Loons.

Gavia. (Forster).

Great Northern Diver, Loon (Gavia imber, Gunn).

The skin of the Loon is used in Russia to make caps for the head and clothing, etc. Garments made of these are very warm, never 
imbibing the least moisture, and are more lasting than could be imagined. These birds build their nests at the edge of small islands or margins of lakes or ponds; they lay only two eggs, and it is very common to find only one pair and their young in one sheet of water; a great proof of their averison to society. Found throughout the Province; an abundant resident.

Black-throated Loon (Gavia arcticus, Linn). Taken at Burrard Inlet.

Pacific Loon (Gavia pacificns, Lawr).

Taken at Comox, Chilliwhack and Victoria. toria.

Red-throated Loon (Gavia lumme, Gunn).

Taken at Esquimalt Harbour, West Coast of Vancouver Island and Chilliwhack.

Family Alcide. Aurs, Murres, and Puffins.

Lunda. (Pallas).

Tufted Puffin (Lunda cirthata, Pall).

Common along the coast of Vancouver Island, Queen Charlotte Islands and Mainland, and on Bare Island, near Sidney, B.C. Breeds throughout its range.

\section{Fratercula (Brisson).}

Horned Puffin (Fratercula corniculata, Naum).

Rare at Masset, Queen Charlotte Islands.

Cerorhinca. (Bonaparte).

*Rhinoceros Auklet (Cerorhinca monocerata, Pall).

Coast of Vancouver Island and Mainland. Breeds on Islands, in Gulf of Georgia.

Ptychoramphus. (Brandt.)

*Cassin's Auklet (Ptychoramphus alcuticus, Pall).

Entire coast line of the Province and West Coast of Vancouver Island. 


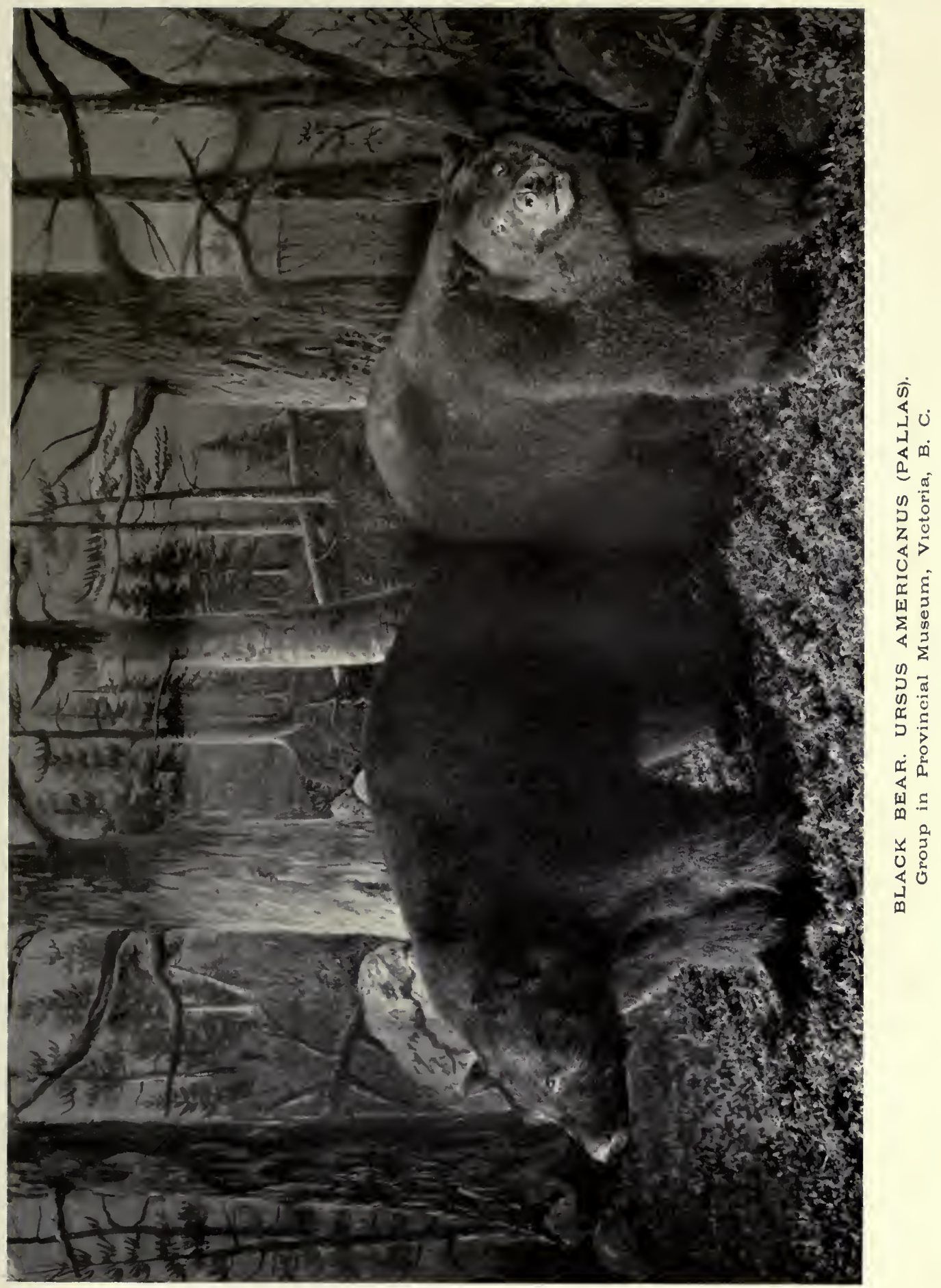




\section{Symthlimorampius. (Brandt).}

Ancient Murrelet (Synthliboramphus antiqus, Gmel).

Not common. West Coast of Vancouver Island and in the Straits, near Victoria.

\section{Brachiraminus. (Brandt).}

Marbled Murrelet (Brachyramphus marmoratus, Gmel).

An abundant resident along the coast of British Columbial and Queen Charlotte Islands. Breeds on Vancouver Island and some of the smaller islands in the Gulf of Georgia and along many of the inlets of the Mainland.

Ceppius. (Pallas).

Pigeon Guillemot (Cepphus columba, Pall).

An abundant resident along the coast from Race Rocks to Alaska, and quite common in Skidegate Inlet, Queen Charlotte Islands.

$$
\text { Uria. (Brisson). }
$$

California Murre, Guillemot (Uria troile californica, Bryant).

A resident along the coast of Vancouver Island and Mainland. Breeds on West Coast of Vancouver Island.

\section{ORDER LONGIPENNES. LONG-WINGED SWIMMERS.}

Family StercoraridDA. Skuas and Jegers.

Stercorarius. (Brisson).

Pomarine Jaeger (Stercorarius pomarinus, Temm).

Taken near Victoria.

Long-tailed Jaeger (Stercorarius longicandus, Vieill). Sumas Lake.

Parasitic Jaeger (Stercorarins parasiticus, Linn).

Victoria and Comox, Vancouver Island. 
Fanily LARIDA. The Gulls and Terns. Pagophila. (Kaup).

Ivory Gull, Snow Gull (Pagophila alba, Gunn).

Dease Lake, Cassiar ; Okanagan Lake.

Rissa. (Stephens).

Pacific Kittiwake (Rissa tridactyla pollicaris, Ridgw).

Taken at Discovery Island and at Queen Charlotte Islands.

LARus. (Linnaus).

Glaucous-winged Gull (Larus glaucescens, Naum).

An abundant resident on the Coast. Breeds on some of the islands in the Gulf of Georgia; also found at Okanagan Lake.

Point Barrow Glaucous Gull (Laius baivovianus).

Found at Comox.

Western Gull (Larus occidentalis, Aud).

An abundant resident on the Coast during the winter months. Takell at Chilliwhack. Breeds in Similkameen Valley.

American Herring Gull (Lavis argentatus smithsonianus, Coues).

An abundant resident on the Coast. It breeds in the interior of Mainland. Common at Metlakatla, Chilliwhack and Okanagan.

California Gull (La'us californicus, Lawr).

A common winter resident on the Coast. Common in the Lower Fraser Valley and Okanagan Lake in winter.

Ring-billed Gull (Larus delawarensis, Ord).

Common along the coast of Vancouver Island and Mainland, and in winter at Okanagan Lake and Clilliwhack. Breeds in the interior, especially to the northward.

Short-billed Gull (Larus brachyrhynchus, Rich).

Common winter resident along the coast of Vancouver Island and Mainland. Common in Lower Fraser Valley and on the lakes in the Cariboo District. 
Heermann's Gull, White-headed Gull (Lurus hermanni, Cass).

Common along the southern coast of Vancourer Island during July and August.

Bonaparte's Gull (Larus philadelphia, Ord).

An abundant resident throughont the Province, and found in great numbers abont the inlets and rivers in March and April. It breeds in the interior of the Province.

\section{Iena. (Leach).}

*Sabine's Gull (Tema sabinii, Sab).

Okanagan Lake.

Steria. (Linnaeus.)

Common Tern (Sterna hirundo, Linn).

West coast of Vancouver Island, Cowichan Gap.

Arctic Tern (Sterna paradisca, Brunn).

From Dease Lake, south to Okanagan Lake.

Hydrochelidon (Boie).

Black Tern. (Hydrochelidon nigra surinamensis, Gmel).

Not common. Sumas, Okanagan Lake, Burrard inlet, Fraser River and interior of Mainland.

\section{Order TUBINARES. Tube-NOSED Swimmers.}

\section{Fayly DiOMedeide. Albatrosses.}

Drom EDE. (Linnæus).

Black-footed Albatross (Diomedea nigripes, And).

West coast of Vanconver Island, Nanaimo, and on Queen Charlotte Islands.

Short-tailed Albatross (Diomedea albatrus, Pall).

Common near Cape Beale, Vanconver Island; but more abundant on the West Coast. 
Family PROCELlaridDA Fulatars and Shearwaters.

Fulatarus. (Stephens).

Pacific Fulmar (Fulmarus glacialis glupischa, Stejn).

Taken at Chemainus and Victoria.

\section{Pufinus. (Brisson.)}

Black-vented Shearwater (Puffinus opisthomelas, Cones).

Not common. Albert Head, Vancouver Island.

Dark-bodied Shearwater (Puffiuıs griscus, Gmel).

Common during migrations on whole coast line of B. C.

Slender-billed Shearwater (Puffinus tenuirostris, Temm).

Common during migrations on whole coast of B. C.

$$
\text { OcEanodroma. (Reichenbach). }
$$

Gray Fork-tailed Petrel (Oceanodroma furcata, Gmel).

Found along both coasts of Vancouver Island, but more common on the Pacific Coast.

Leach's Fork-tailed Petrel. White-rumped Petrel (Oceanodroma lcucorrhoa, Vieill).

West Coast of Vancouver Island.

\section{ORDER STEGANOPODES. TOTIPALMATE SWIMMERS.}

\section{Fanily PHALACROCORACIDA. Cormorants.}

\section{Phalacrocorax. (Brisson).}

White-crested Cormorant (Phalacrocorax dilophus cincinnatus, Brandt).

Common on both coasts of Vancouver Island and coast of Mainland from Race Rocks to Alaska.

Brandt's Cormorant, Pencilled Cormorant (Phalacrocorax pencillatus, Brandt).

Not common. Vancouver Island. 


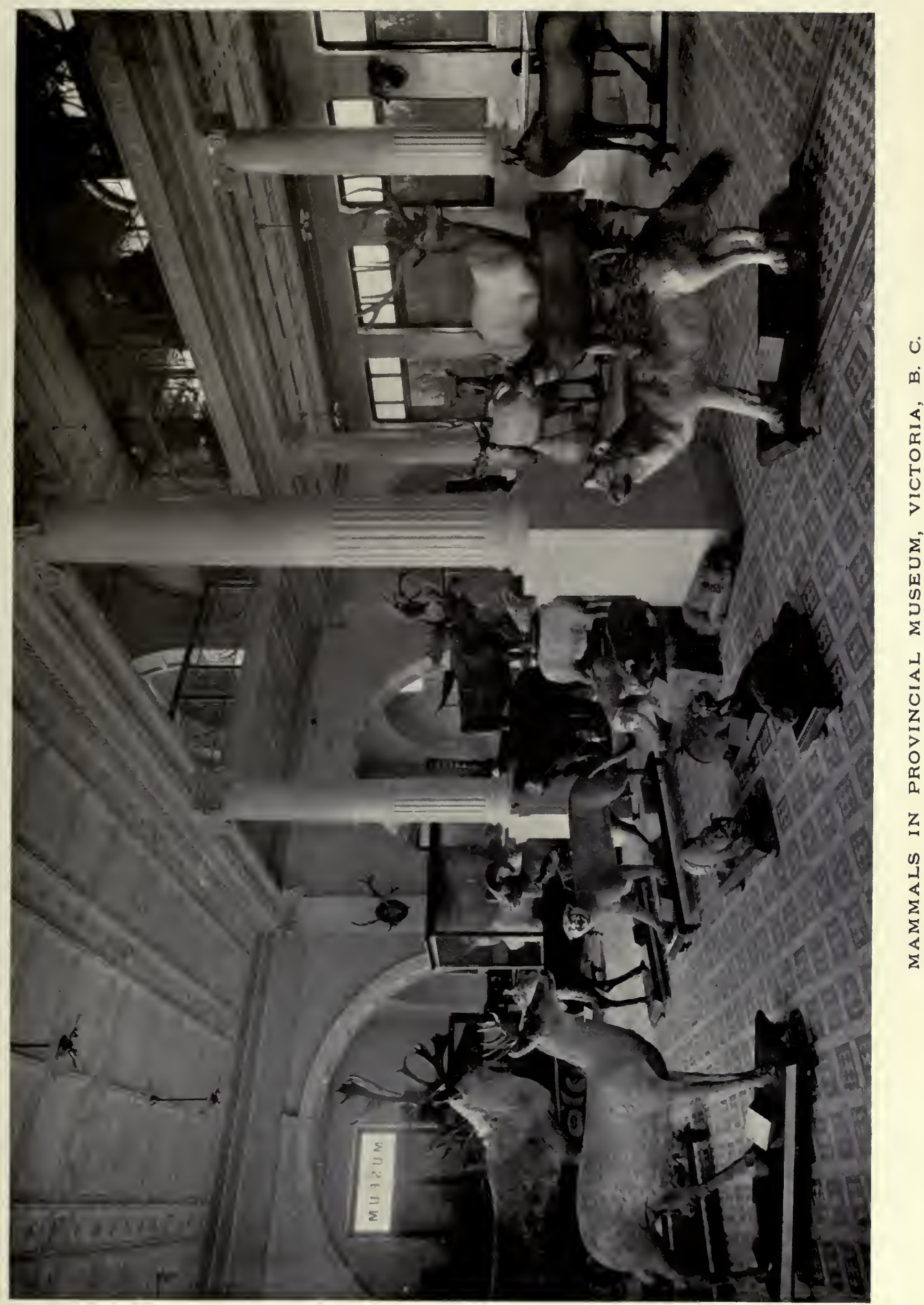



Violet-green Cormorant (Plalacrocorax pelagicus robustus, Ridgw).

Abundant on both coasts of the Island; has been taken as far north as Port Simpson. Breeds on Islands close to Sidney Island.

Family Pleted Nido.e. Pelicass.

Pelecaxus. (Linnarus).

American White Pelican (Pelecanus erythrorhyuchos, Gmel).

Not common. Sicamous. Alexandria Bridge, Tranquille, Comox, Chilliwhack and Okanagan.

California Brown Pelican (Pelecanus californicus, Ridgw).

Not common. Race Rocks and Sumas Lake.

\section{ORDER ANSERES. LAMELLIROSTRAL SwimmerS}

Fayily AXatide. Mergansers, Ducks, Geese and SWAxs.

Merganser. (Brisson).

American Merganser (Merganser americunus, Cass).

Found throughout the Province. Taken on West Coast of Vancouver Island in May: also on Queen Charlotte Islands in July and on Okanagan Lake all winter.

\section{Red-breasted Merganser (Merganser serrator, Linn).}

The red-breasted Merganser inhabits most parts of the north of Europe on the continent and as high as Iceland: also in the Russian dominions about the great rivers of Siberia. It is said to be frequent in Greenland, where it breeds on the shores. The inhabitants often take it by darts thrown at it. especially in August, being then in moult. At Hudson's Bar, according to Hutchins, ther come in pairs about the middle of June, as soon as the ice breaks up. and build soon after their arrival, chiefly on dry spots of ground on the islands; lay from eight to thirteen white eggs the size of those of a duck; the nest is made of withered grass and lined with down of the breast. In abundant resident. 
LopHodrTEs. (Reichenbach).

Hooded Merganser (Lophodytes cucullatus, Linn).

This is also an abundant resident and more common than the last named species. Nests in holes of trees.

Axas. (Linnæus).

Mallard (Anas boschas, Linn).

This is the original of the common domesticated duck which is so serviceable to man. Its flesh is in general and high estimation, and the ingenuity of man in every country where it frequents has been employed in inventing stratagems to overreach these wary birds and procure a delicacy for the table. It is an abundant resident. Breeds in almost every suitable portion of the Province.

\section{Chaulelasius. (Bonaparte).}

Gadwall, Gray Duck (Chaulelasmus sterpera, Linn).

Not common. Victoria, Chilliwhack and Okanagan.

Mareca. (Stephens).

European Widgeon (Mareca penelope, Linn).

Rare. Victoria and Saanich.

American Widgeon (Mareca americana, Gmel).

A common wintel resident on the coast. Found also in Chilliwhack and Okanagan. Breeds on lakes above Clinton.

Netron. (Kaup).

Green-winged Teal (Nettion carolinensis, Gmel).

Common thronghout the winter near Victoria. Rare on Queen Charlotte Islands. Breeds in the interior of the Mainland.

Quergueiula. (Stepliens).

Blue-winged Teal (Qucrquedula discors, Linn).

Not common on the coast. Taken at Chilliwhack. 
Cinnamon Teal (Querquedula eyunoptera, Vieill).

A summer visitor in the interior of the Province. Taken at Chilliwhack and Okauagan.

\section{Spatula: (Boie.)}

Shoveller, Spoon-bill (Spatula clypeata, Linn).

Common on Mainland; rarely met with on Vancouver Island. Taken in Lower Fraser Valley about Sumas Lake, and on Okanagan Lake.

\section{DAFin. (Stephens.)}

Pintail, Sprigtail (Dafila acuta, Linn).

This is one of the most elegant and graceful of our ducks, either on land or water, walking and swimming, with the long-pointed tail elevated and the thin, sinuous neck swaying in all directions. It is shy and vigilant, but owing to its habit of elustering close in groups about the margins of pools, where the reeds or bush-wood favour approach, it is sometimes slaughtered in numbers with ease; and if the gunner be ready with another barrel, additional birds may usually be procured as they fly off in a compact flock.

Aix. (Boie.)

Wood Duck (Aix spona, Linn).

Not common. A summer resident on Island and Mainland. Taken at Chilliwhack and Okanagan.

\section{Aгтнга. (Boie).}

Red-head Pochard (Aythya americana, Eyt).

A winter resident on the Coast, but nowhere common. Breeds on the Cariboo Road lakes.

Canvas-back Duck (Aythya vallisneria, Wils).

A winter resident on the Coast. Taken on Okanagan Lake and 108-Mile House. Breeds near 108-Mile House, Cariboo Road.

American Scaup Back, Blue-bill (Aythya marila, Linn).

Abundant on the Coast in winter. Breeds in the interior of Mainland. 
Lesser Scaup Duck (Aythya affinis, Eyt).

Common on Vancouver Island. Common in Lower Fraser and found all winter on Okanagan Lake.

Ring-necked Duck (Aythya collaris, Donov).

Not common on Vancourer Island. Common in Lower Fraser Valley, and found all winter on Okanagan Lake.

\section{Craxgula. (Leach).}

American Gold-eye, Whistler (Clangula americana, Faxon).

A common winter resident on the Coast. Taken at Chilliwhack and Okanagan. Breeds in the interior of the Mainland.

Barrow's Golden-eye (Clangula islandica, Gmel).

Not common. It winters on the Coast. A few have been taken on Vancourer Island and at Okanagan. Plentiful on the lakes along the Cariboo Road during nesting season.

$$
\text { Charitonetta. (Stejner). }
$$

Buffle-head, Butter-ball (Charitonetta albeola, Linn).

An abundant winter resident on the Coast. Breeds in the interior of the Mainland. Common at Metlakatla.

\section{Harelda. (Stephens.)}

Long-tailed Duck, Old Squaw (Harelda hyemalis, Linn).

Common on the coast of Vancouver Island and Mainland. Taken at Chilliwhack and at Metlakatla.

\section{Histrionicus. (Lesson).}

Harelquin Duck (Histrioniens histrionicus, Linn).

Common on the Cuast. Taken at Bear River, Vancouver Island; and Chilliwhack. Rare on Queen Charlotte Islands.

$$
\text { DeNdrocyGNA. (Swainson.) }
$$

Fulvous Tree Duck (Dendrocygna fulva, Gmel).

Taken at New Alberni, Vancouver Island. 


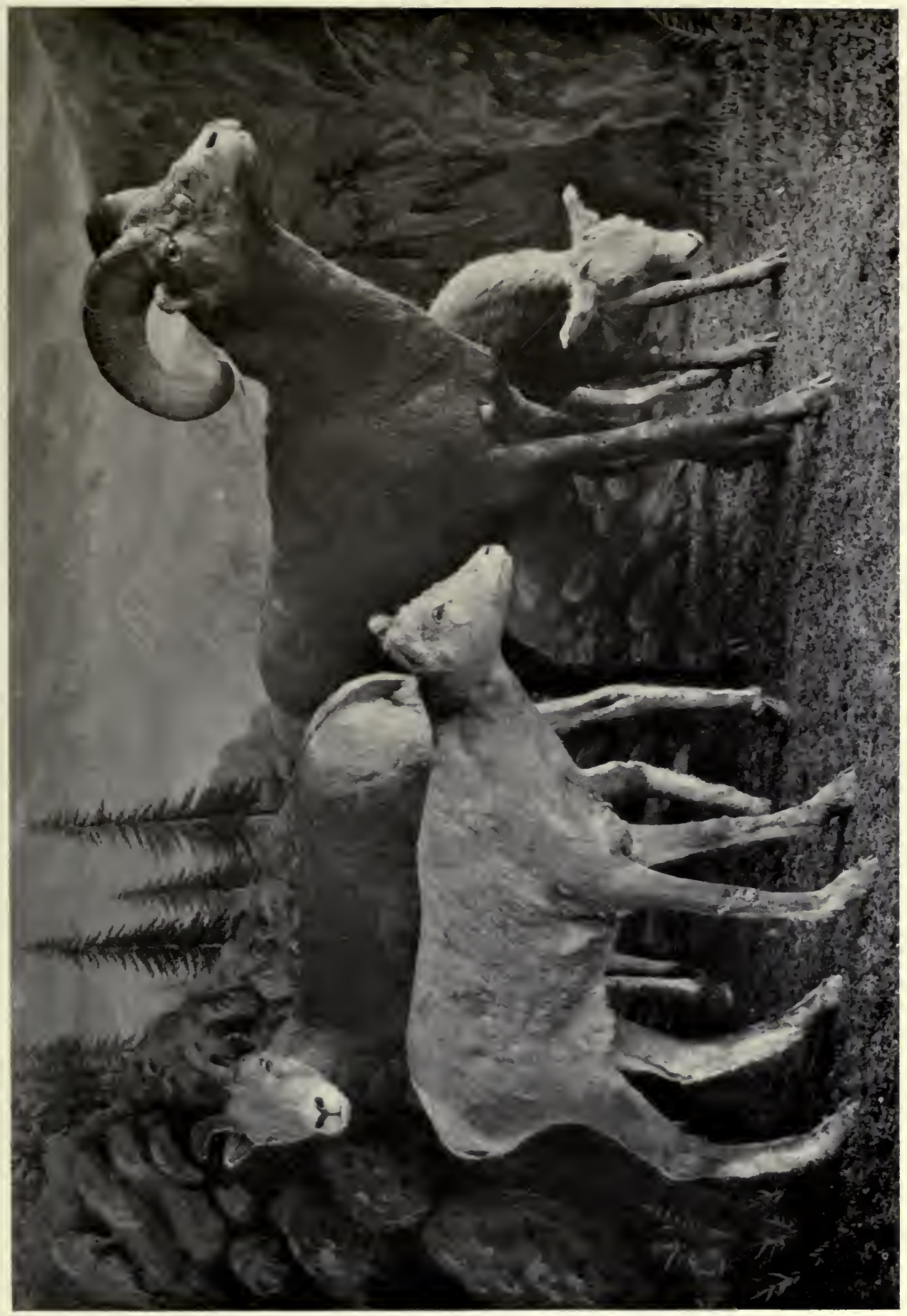





\section{Ordemia. (Fleming).}

American Black Scoter (Oidemia americana, Swains).

Not common. Taken at Victoria and Port Simpson. Fairly common at Metlakatla.

White-winged Scoter (Oidemia deglandi, Bonap).

An abundant resident and is found throughont the year on the Coast. Common at Metlakatla. Taken at Chilliwhack and Okanagan.

Surf Scoter, Sea Coot (Oidemia perspicillata, Linn).

Abundant resident along the coast of Vancouver Island and Mainland. Found at Chilliwhack and Okanagan. Common at Metlakatla.

\section{Erismatura. (Bonaparte.)}

Ruddy Duck (Erismatura jamaicensis, Gmel).

Not common on the Coast. Breeds on the lakes along the Cariboo road.

\section{Chen. (Boie.)}

Lesser Snow Goose (Chen hyperborea, Pall).

A winter resident on the Coast.

Ross's Snow Goose (Chen rossii, Cassin).

Rare in British Columbia. Taken at Comox and Kuper Island.

Anser. (Brisson.)

American White-fronted Goose (Anser albifrons gambeli, Hartl).

Abundant on the Coast in winter. Taken at Cowichan Lake, Sumas, and Okanagan Lakes, and at Metlakatla. Breeds both on Island and Mainland.

\section{Branta. (Scopoli.)}

- Canada Goose (Branta canadensis, Linn).

An abundant winter resident on the Coast. Breeds in the interior of the Mainland. 
*Hutchin's Goose (Branta canadensis hutchinsii, Rich).

Abundant in the spring and fall migrations, and winters on the Coast.

*White-cheeked Goose (Branta canadensis occidentalis, Baird).

Taken at Chilliwhack.

Cackling Goose (Branta canadensis minima, Ridgw).

Winter resident on the Coast. Taken at Elk Lake, near Victoria; also Chilliwhack and Okanagan.

Brant (Branta bernicla glancogastra, Brehm).

Taken at Comox, Vancouver Island.

Black Brant (Branta nigricans, Lawr').

An abundant winter resident on the Coast.

\section{Philacte. (Bannister.)}

Emperor Goose (Philacte canagica, Sevast).

Taken at Chemainus, Vancouver Island.

\section{OLor. (Wagler.)}

Whistling Swan (Olor columbiamus, Ord).

This bird breeds in the great marshes near the Yukon mouth. The eggs, two in number, vary from pure white to fulvous, as do the parents on the head and neck, apparently without regard to age. The eggs are usually in a tussock quite surrounded with water, so that the female must sometimes set with her feet in the water. They are usually laid about June 1st. In July the swans moult and cannot fly, and the Indians have great sport spearing them with bone tridents. They are very shy birds, and usually shot on the wing, or $^{\circ}$ with a bullet. This species, if hung long enough, is tender, wel!flavoured and excellent eating.

*Trumpeter Swan (Olor buccinator, Rich).

Found at Sumas and Okanagan. 


\title{
ORder HERODIONES. Herons, IbISEs, Etc.
}

\author{
FaMILY IBIDID.E. IBISES.
}

\section{P'leganis. (Käup.)}

White-faced Glossy Ibis (Plegatis gaurunna, Linn).

Only two specimens known to be taken in the Province; one at Sardis, B. C., the other at mouth of Fraser River.

\section{Fanily hrideid.t. Heroxs and Bittriess.}

\section{Botachus. (Hermann.)}

\section{American Bittern (Botaurus lentiginosus, Montag).}

When the Bittern is disturbed at his meditation he gives a vigorous spring, croaks at the moment in a manner highly expressive of his disgust, and flies oft as fast as he can, though in rather a loose, lumbering way. He is very easily shot on the wing. Easily hit and dropping at a touch, even of fine shot. When winged he croaks painfully as he drops, and no sooner does he touch the ground than he gathers himself in defensive attitude to resent aggression as best he can. He fights well, and with more spirit and determination than he might be expected to show. He has a very ugly way of pointing his resistance with quick thrusts of his spear-like bill, capable of inflicting no slight wound on an incautious hand. It is common throughout the greater portion of the Province. Breeds both east and west of Cascales.

\section{Aruka. (Limnous).}

\section{Great Blue Heron (Ardea herodias, Linn).}

Wherever placed, on tree, bush or rock, the nest of the Heron is a large béd of twigs, more or less matted together with grasses and weeds, some two feet in dianeter and about one-third as high. Two or three eggs are latid, they measure 2.50 by 1.50 , and are rather narrowly elliptical, with both ends of about the same shape; the colour is a pale, dull, greenisl-blue, varying in shade in different specimens, not always uniform over the same eggs. It is a common resident on the Coast and is quite common at Sumas Lake and Okanagan. Breeds throughout its range. 
North-west Coast Heron (Ardea herodius fannini, Chapman).

This bird, named after the late John Fannin by Frank M. Chapman, is quite a common species found at Skidegate, Queen Charlotte Islands, during the montl of August.

Egrette. (Forester).

Snowy Heron (Egrette candidissima, Gmel).

Rare in British Columbia. 'Two specimens collected at Burrard Inlet.

\section{Order PALUdicolaE. Cranes, Rails, Etc.}

\section{Family GRUIDA. Cranes.}

Grus. (Pallas.)

*Little Brown Crane (Grus cunadensis, Linn).

The Little Brown Crane, when proceeding from one favourite resort to another or when migrating, flies high, and not infrequently their approach is heralded, before they are in sight, by their incessant whooping clamour. While feeding they are generally silent. Such ponderous bodies, moving with slowly beating wings, give a great idea of momentum from mere weight of force of motion without swiftmess, for they plod along lieavily, seeming to need every inch of their ample wings to sustain themselves. One would think they must soon alight fatigued with such exertion, but the raucous cries continue, and the birds fly on for miles, in Indian file, under some trusty leader, who croaks his loarse orders, implicitly obeyed. Each bird keeps his place in the ranks, the advancing column now rises higher over some suspected spot, now falls along an open sandy reach, swaying meanwhile to the right or left; as it passes on the individual birds are blended in the hazy distance, till, just before lost to view the line becomes like an immense serpent gliding mysteriously through the air. It is common thronghout the Province during migrations.

Sandhill Crane (Grus mexicana, Mull).

Common throughout the Province; it breeds in the interior of the Mainland. Numbers pass over Victoria in the spring and autumn migration. 

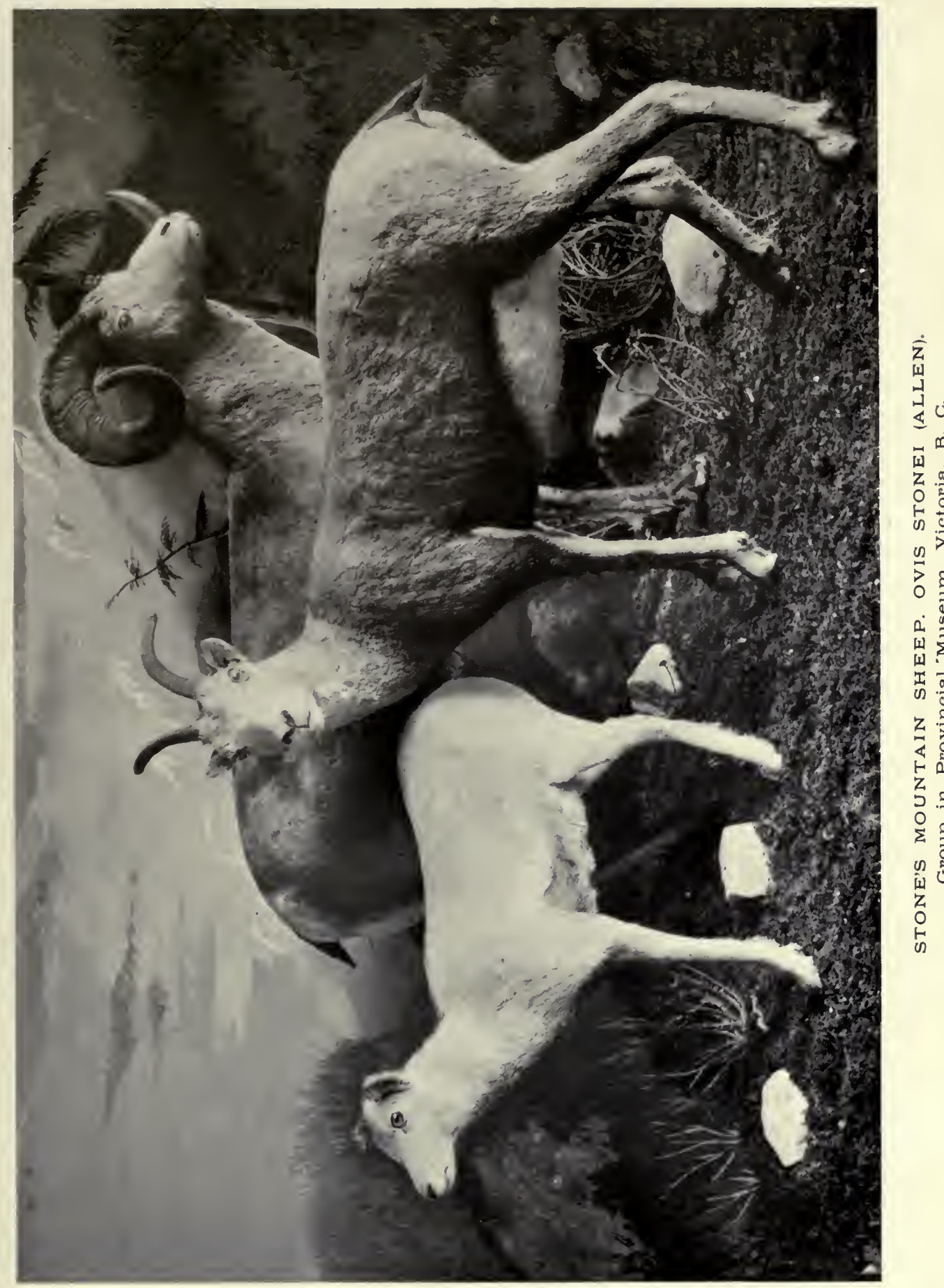



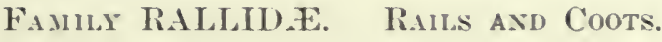

\section{Rallus. (Linnaeus)}

Virginia Rail (Rallus virgini(mus, Linn).

Tolerably common on Island and Mainland: breeds close to Victoria. Taken at Chilliwhack and Okanagan.

\section{Porzasia. (V'ieillot.)}

Carolina Rail (Poranza carolina, Limn).

Found on Vancouver Island and Mainland. Rare on Queen Cliarlotte Islands. Common east of Cascades.

\section{Fulica. (Linnaeus.)}

\section{American Coot, Mud-hen (Fulica americana, Gmel).}

Not only is the Coot extensively and rery generally dispersed orer North America, but, unlike most water birds, its breeding range is almost equally wide. There is a regular migration in the spring and fall, when, in company with other water-fowls, most of the Coots are on their way to or from the rather northerly regions where they especially breed, only a few lingering in suitable places along the route to nest. Some birds leare the Province in the fall to winter in the south, penetrating into Mexico, the West Indies and Central America. The nest is said to be sometimes a floating one, moored to the stems of reeds, rising and falling with the tide. It is a common resident on Vancouver Island and Mainland. Breeds throughout its range.

\section{ORDER LIMICOLAE. SHORE BirdS.}

Fantr PHalaropotid.E. Phalaropes.

Crimophilus. (Viellot.)

Red Phalarope (Crymophilus fulicarius, Linn). Taken at Clover Point, Victoria.

\section{Phillaropus. (Brisson.)}

Northern Phalarope (Phalaropus lobatus, Linn).

Abundant along the coast of Island and Mainland in the spring and autumn. Taken at Chilliwhack. Okanagan and Burrard Inlet. 


\section{Steganopus. (Vieillot.)}

Wilson's Phalarope (Stegunopus tricolor, Vieill).

Found at Clilliwhack.

Fanily SCOLOPACIDA. Sxipes, SANd-pipers, ETC.

$$
\text { Galingo. (Leach.) }
$$

Wilson's Snipe (Gallinago delicata, Ord).

Common throughout the Province, on Island and Mainland. Breeds in interior.

\section{Macrorhampiuss. (Leach.)}

Long-billed Dowitcher, Red-breasted Snipe (Macrorhamphus scolopaccus, Say).

Tolerably abundant throughout the Province and West Coast of Vanconver Island. Taken at Chilliwliack and Metlakatla. The nest of this bird is a simple hollow in the ground in the centre of a marshy spot on the border of a lake, with scarcely any lining whatever--nothing in the shape of a nest to bring away.

\section{Micropala ma. (Baird.)}

Stilt Sandpiper (Micropalama himantopus, Bonap). Taken at Chilliwhack.

Tring.. (Limmaens.)

Knot, Robin Snipe (Tringa canutus, Linn).

Abundant during migrations.

\section{Actopromas. (Kaup.)}

Sharp-tailed Sandpiper (Actodromas acuminata, Horsf).

Taken at Masset, Queen Charlotte Islands.

Pectoral Sandpiper (Actodiomas maculata, Vieill).

Taken along the Coast during migrations, at Chilliwhack and Okanagan. 
Baird's Sandpiper (Aetodromes bairdii, Cones).

Distributed along the coast of Vancouver Island and Mainland. T'aken at Clilliwlıack and Okanagan, and at Clover Point, Victoria.

Least Sandpiper (Actodromas mimutilla, Vieill).

Common along the coast of Island and Mainland. This little bird is one of several species that collectively inhabit all the world and resemble each other very closely.

\section{Plemida. (Cuvier.)}

Dunlin (Pelidna alpina, Limn).

Found at Comox.

Red-backed Sandpiper (Pelialna alpina salihalina, Vieillot).

Common in the spring and antumn migrations along the coast of Island and Mainland; taken at Chilliwhack.

\section{Ereunetes. (Hliger.)}

Semipalmated Sandpiper (Erennetes pusillus, Linn).

Not nncommon in migration along the Coast. 'Taken at Chilliwhack, Okanagan and Metlakatla.

Western Semipalmated Sandpiper (Evennetes pusillus oeeidentalis, Law' $\mathbf{r}^{\text {). }}$

Abundant in the fall along the Coast. Taken near Victoria and Chilliwhack.

$$
\text { Calidis. (Cuvier.) }
$$

Sanderling (Calidris arenaria, Limn).

Not common. Several lave been taken near Victoria, also at Chilliwhack and Metlakatla.

\section{Limosi. (Brisson.)}

Marbled Godwit (Limosa fedoa, Limn).

The whole of British Columbia. Breeds chiefly west of Cascades. Taken at Port Simpson.

\section{ToTanus. (Bechstein.)}

Greater Yellow-legs (Totanus melanoleneus, Gmel).

Common along the Coast in winter. Taken at Clayoqnot, Chilliwhack and Okanagan. Breeds around the lakes at Clinton. 
Lesser Yellow-legs (Totanus flavipes, Gmel).

Tolerably common throughout the Province. Winters on Coast. Taken at Chilliwhack and Okanagan.

\section{Helodromas. (Kaup.)}

Solitary Sandpiper (Helodromas solitarius, Wils).

Common.

Western Solitary Sandpiper (Helodromas solitarius cinnamomeus, Brewster).

Taken at Chilliwhack and Okanagan.

\section{Srypheyia. (Rafinesque.)}

*Western Willet (Symphemia semipalmata inornata, Brewster). Found at Clorer Point. Victoria.

\section{Heteractitis. (Stejneger).}

Wandering Tatler (Heteractitis incanus, Gmel).

Tolerably common along the coast of Vancourer Island and the Mainland. Taken at Clayoquot and at Skidegate, Queen Charlotte Islands.

\section{BarTRaMia. (Lesson).}

Bartramian Sandpiper (Bartramia longicauda, Bechst).

Taken at Comox, Vancouver Island, and at 150-Mile House. Cariboo Road.

$$
\text { Trixgites. (Cabanis). }
$$

Buff-breasted Sandpiper (Tryngites subruficollis, Vieill).

Not common. Taken at Chilliwhack.

\section{Actiтis. (Illiger).}

\section{Spotted Sandpiper (Actitis macularia, Linn).}

Found along the entire coast. Taken at Clayoquot, Vancouver Island, and at Skidegate, Queen Charlotte Islands. Taken also at Chilliwhack and Okanagan. 


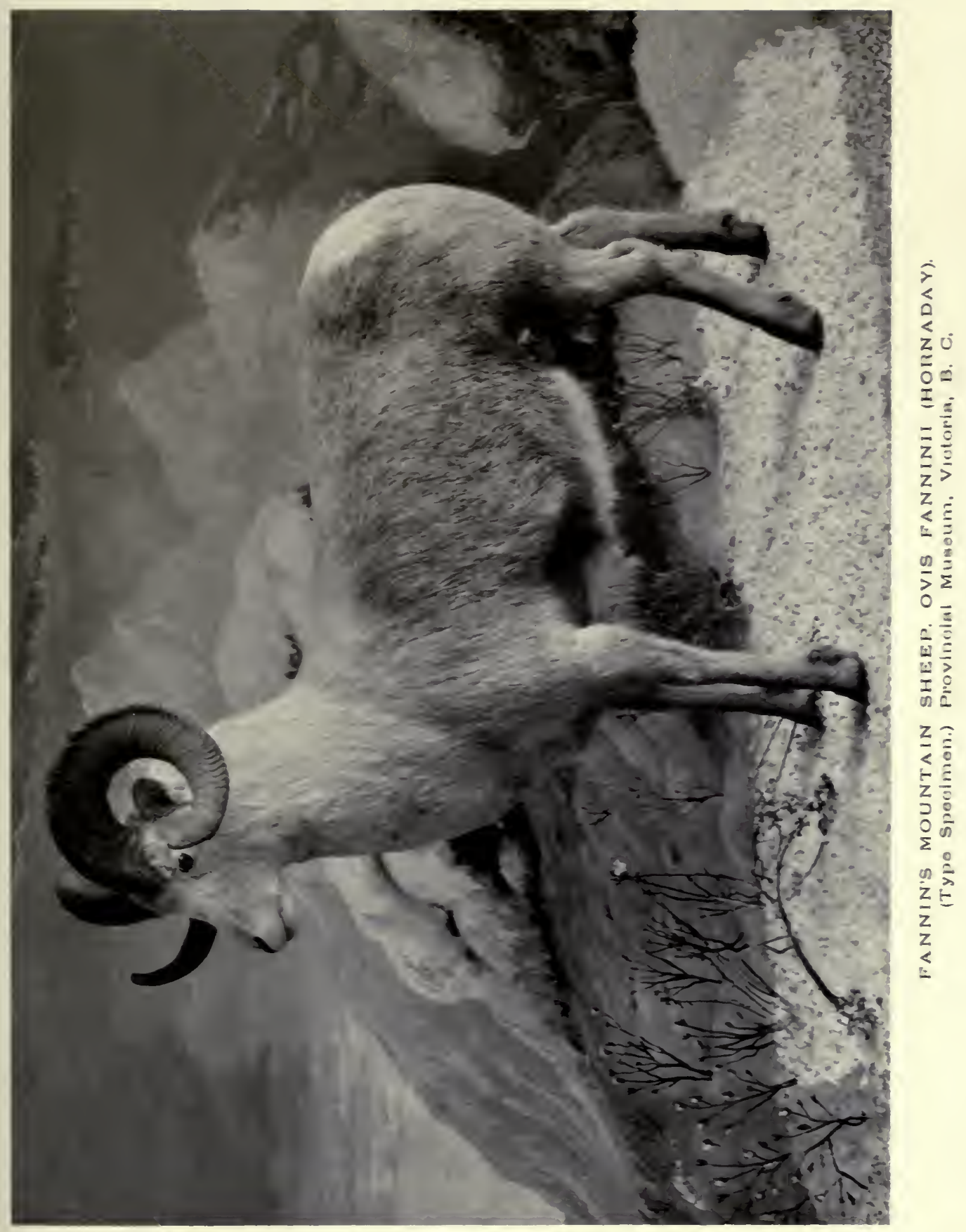



Numenues. (Brisson).

Long-billed Curlew (Numenius longirostris, Wils).

This bird is by no means confined to the vicinity of the water, but on the contrary is often seen on extensive, dry plains, where it feeds on various molluses, insects and berries, which it deftly secures with its extraordinarily long bill. The length and curve of this member, measuring sometimes eight or nine inches in length, gives the bird a singular and unmistakable appearance, either in flight or when gathering its food. Its voice is sonorous and not at all musical; during the breeding season in particular its harsh cries of alarm resound when the salfety of its nest or young is threatened. In the fall, when food is plenty, it becomes very fat and affords delicate eating. Rare on the Coast, but more common in the interior of the Mainland, south through the Okanagan.

Hudsonian Curlew (Numenius hudsonicus, Lath).

Not common on Island and Mainland. Taken at Clayoquot, Port Simpson and at Cadboro Bay, near Victoria.

Family Charadritde. Plovers, Etc.

Charadrius. (Linnaus).

Black-bellied Plover (Charadrius squatarola, Linn).

Abundant during migration along the Coast. Taken at Chilliwhack and Okanagan.

American Golden Plover (Charadrius dominieus. Mull).

Common on the Coast during migration. Taken at Chilliwhack, Okanagan, Metlakatla and Port Simpson.

*Asiatic Golden Plover (Charadrius dominicus fulvus, Gmel).

Found at Comox.

Eginlitis. (Boie).

Kildeer Plover (Egialitis vocifera, Linn).

Found throughout the Province. Taken at Chilliwhack and Okanagan.

Semipalmated Plover (Agialitis semipalmata, Bonap).

Not common. Taken on the West Coast of Vancouver Island at Ucluelet and Clayoquot; also at Cadboro Bay, Victoria. 
Fanily APHRIZIDE. Surf-birds and Turnstones.

Aphriza. (Audubon).

Surf-bird (Aphriza virgata, Gmel).

Not uncommon along the entire coast line of the Province. Taken at Clayoquot and Port Simpson.

\section{Arenaria. (Brisson).}

Turnstone (Arenaria interpres, Linn).

Along the entire coast line, but not common. Taken at Port Simpson and Sidney Island; also Sumas Lake.

Black Turnstone (Arenaria melanocephala, Vig).

Common along the entire coast of the Province. Taken at Clayoquot, Skidegate, Queen Charlotte Islands, and near Victoria throughout the winter.

\section{Fanily HAMATOPODIDA. Oyster-Catchers.}

\section{Hexatopus. (Linnacus).}

Black Oyster-catcher (Hamatopus bachmani, And).

Abundant along the entire coast of Island and Mainland. Common at Skidegate, Queen Charlotte Islands. Breeds throughout its range.

\section{Order GallinaE. Gallinaceous Birds.}

Fanify Tetraonide. Grouse, Partringes, Etc.

Oreortyx. (Baird).

Mountain Partridge (Oreortyx pictus, Dougl).

Common on Vancouver Island. Introduced from California.

Lophor'Tx. (Bonaparte).

California Partridge (Lophortyx californieus, Shaw).

Common on Vancouver Island. Introduced from California. 


\section{Dendragales. (Elliot).}

Sooty Grouse (Dendıagupus obscurvs fuliginosus, Ridgw).

Abundant west of Cascade Mountains, including Vanconver Island, Queen Charlotte Islands and all the larger Islands along the coast.

Richardson's Grouse (Dendraynpus obscurus richardsonii, Dongl).

An abundant resident east of Cascade Momntains to Rocky Mountains.

$$
\text { Canacintas. (Stejneger). }
$$

Franklin's Grouse (Canachites franlilinii, Dougl).

An abundant resident throughout the wooded portion of the interior east of the Cascade Mountains from Okanagan to Cassiar.

Boxasa. (Stepliens).

Canadian Ruffed Grouse (Bonasa lmbellus togata, Linn). . .

An abundant resident east of and including the Cascade Mountains. Taken at Chilliwhack.

Gray Ruffed Grouse (Bonasa umbellıs umbelloides, Dongl).

Rocky Mountain District, Soda Creek, Bearer Pass and Okanagan.

Oregon Ruffed Grouse (Bonasa umbellus sabini, Dougl).

An abundant resident on Vancouver Island and all the larger Islands on the coast and on the mainland west of Cascade Mountains.

LAgopus. (Brisson).

Willow Ptarmigan (Lagopus lagopus, Linn).

Northern portion of British Columbia. Dease Lake, Cassiar; Log Cabin, Atlin.

Rock Ptarmigan (Lagopus rupestris, Gmel).

Quite common at Atlin.

White-tailed Ptarmigan (Lagopus leucu'us, Swains \& Rich).

Ptarmigan may be said to be simply Grouse that turn white in winter. They are the only members of this family of birds in which 
such a remarkable seasonal change of plumage occurs. All the Ptarmigan are Grouse of boreal or alpine distribution, only reaching sea-level in the higher latitudes, elsewhere confined to mountains. The present species is immediately distinguished from the rest by having the tail white at all seasons, as implied in its name. In wiuter this Ptarmigan is entirely snow-white, in summer the plumage is rariegated with ochrey and tawny, in flnely undulated patterns, much of the under parts, however, and wings, remaining white. The Ptarmigan feeds upon the leaves and stalks of various alpine plants, being particularly fond of those of a species of Cassia. It also lives largely upon insects, and in winter is said to subsist on the buds and leaves of the pines and firs. It is found on the summit of most mountains of the Mainland and snow peaks of Vancouver Island.

Pedracetes. (Baird).

Columbian Sharp-tailed Grouse. Prairie Chicken (Pediocetes phasianellus columbianus, Ord).

At one time an abundant resident east of Cascade Range through the southern portions of the Province. Common near Vernon.

Centrocercus. (Swainson).

*Sage Grouse (Centrocercus urophasianus, Bonap).

Found at Osoyoos Lake.

Finily PHASIANide. Pheasants.

Phasianus. (Limnaeus).

Ring-necked Pheasant (Phasianus torquatus, Linn).

Abundant on Tancouver Island and in the Lower Fraser River Valley and other portions of the Mainland. Introduced from China, now thoroughly naturalised.

\section{Order COLUMBAE. Pigeons.}

\section{Family COLUmbide. Pigeons.}

Columba. (Linnæus).

Band-tailed Pigeon (Columba fasciata, Say).

A common summer resident in the south-western portions of the Province, including Vancouver Island. 


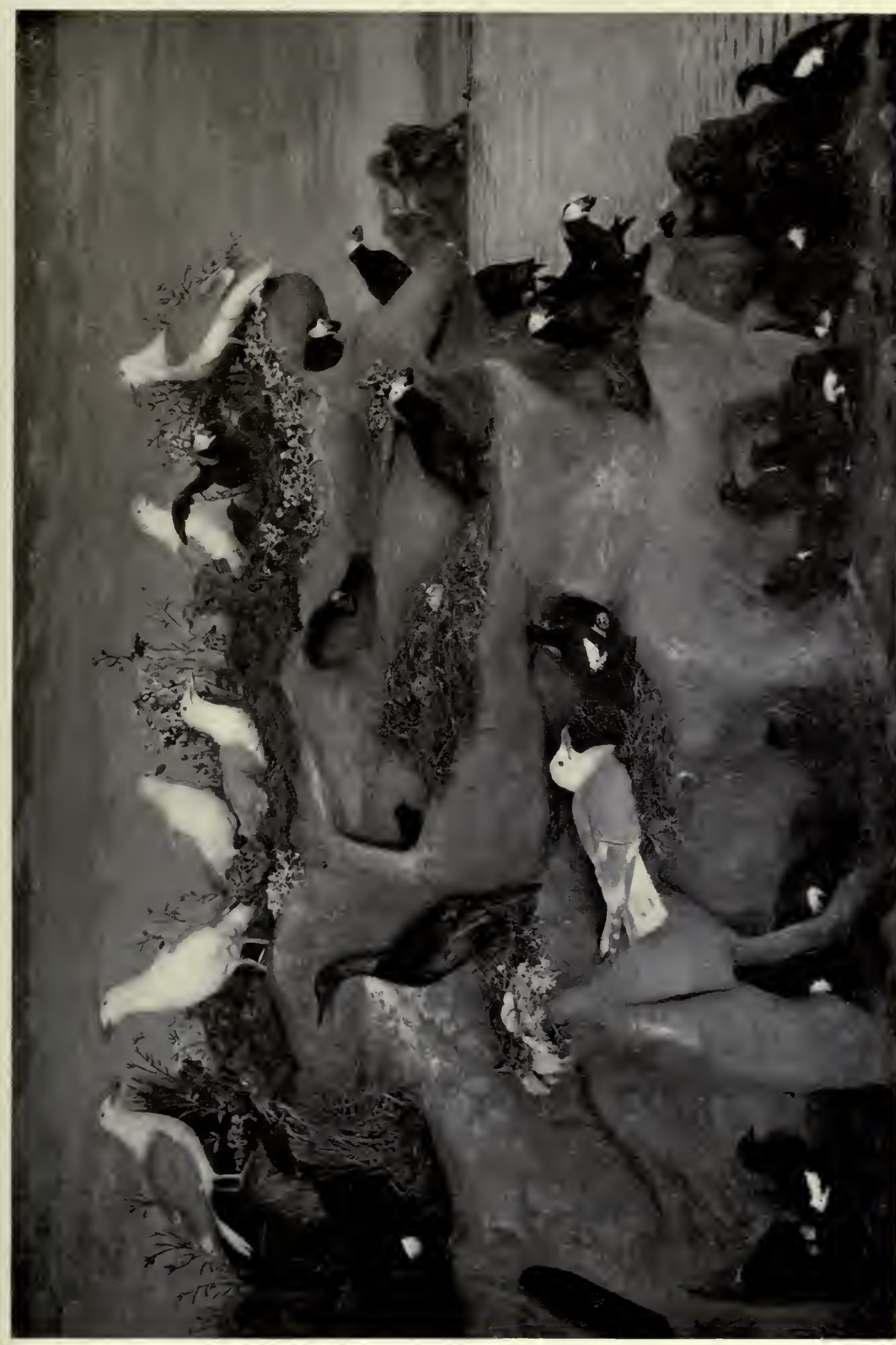



Eсторьsтres. (Swainson).

*Passenger Pigeon (Ectopistes migratorius, Limn).

Zenaidura. (Bonaparte).

Mourning Dove (Zenaidura macroura, Linn)..

Not common on Vancouver Island. Common in the Okanagan. Taken at Chilliwhack and Metlakatla.

\section{ORder RAPTORES. BIRds OF PREY.}

Family Cathartide. American Vultures.

Cathartes. (Illeger).

Turkey Vulture (Cathartes aura, Linn).

Tolerably common on Vancouver Island and Mainland. Taken at Chilliwhack and Okanagan.

Gymogrps. (Lesson).

*California Vulture (Gymnogyps californianus, Shaw).

Found at mouth of Fraser River.

Family falconide. Falcons, Hawis, Eagles, Etc.

Circus. (Lacépéde.

Marsh Hawk (Circus hudsonius, Linn).

Common on Vancouver Island and Mainland. Taken at Chilliwhack and Okanagan.

$$
\text { Accipiter. (Brisson). }
$$

Sharp-shinned Hawk (Accipiter velox, Wils).

Abundant on Vancouver Island and portions of the Mainland.

Taken at Chilliwhack and Okanagan.

Cooper's Hawk (Accipiter cooperii, Bonap).

Found on Vancouver Island and Mainland. Taken at Sicamous, Chilliwhack and Okanagan.

American Goshawk (Accipiter atricapillus, Wils).

Rather common in interior of Province. Taken on Vancouver Island, Chilliwhack and Okanagan. 
Western Goshawk (Aceipiter atricapillus striatulus, Ridgw).

Common throughout the I'rovince. Taken at skidegate, Queen Charlotte Islands.

\section{Buteo. (Cuvier).}

Western Red-tailed Hawk (Butco borealis calurus, Cass).

An abundant resident on Vaucouver Island and Coast of Mainland. Taken at Chilliwhack and Okanagan. Tare at Masset, Queen Charlotte Islands.

*Red-bellied Hawk (Buteo lincatus elegans, Cass).

Burrard Inlet and Chilliwhatek.

Swainson's Hawk (Butco suainsoni, Bonap).

Not common on Vanconver Island. Taken at Victoria, Union, Chilliwhack and Okanagan.

Archisutro. (Brehm).

American Rough-legged Hawk (Archibuteo lagopus sanctijohannis, Gmel).

Not common. Found on Vancouver Island and Mainland. Taken at Chilliwhack and Okanagan.

\section{Aquila. (Brisson).}

Golden Eagle (Aquila chrysactos, Linn).

Found throughout the entire Province. Rare on Vancouver Island. A resident.

Halizetus. (Savigny).

Bald Eagle (Halicetus leucocephalus alascanus, C. H. Townsend).

An abundant resident throughout the entire Province, on Island and Mainland. Common on Queen Charlotte Islands. Breeds throughout its range.

$$
\text { Falco. (Linnaeus). }
$$

Whịte Gyrfalcon (Faleo islandus, Brïn).

Saanich, Vancouver Island.

Gyrfalcon (Falco rusticolus gyrfalco, Linn).

Taken at Comox and Chilliwhack. 
Prairie Falcon (F'alco mericanus, Schleg).

Taken at Chilliwhack and Kamloops.

Duck Hawk (Fulco peregrinus anutum, Bonap).

More common on Mainland than Tanconver Island. Taken in the Okanagan comntry.

Peale's Falcon (Falco peregrinus pealei, Ridgw).

Found chiefly along the Coast of Mainland and Vancouver Island. Taken at Cadboro Bay, near Victoria; at Chilliwhack and Metlakatla.

Pigeon Hawk (F'alco columbarius, Linn).

Apparently mole common east of the Coast Range. Has been taken on the coast; also at Chilliwhack and Okanagan.

Black Merlin (F'alco columbatius suckleyi, Ridgw).

Abundant in summer on Vancouver Island and portions of the Mainland. Taken at Chilliwhack.

Richardson's Merlin (F'aleo richardsonii, Ridgw).

Not common on Vanconver Island. Taken near Victoria, Chilliwhack and Okanagan.

Desert Sparrow Hawk (Falco sparverius phalaua, Lesson).

Aloundant througliont the southern portions of the Mainland, including Vancouver Island, from the coast to Rocky Mountains.

\section{Pandion. (Sarigny).}

American Osprey. Fish Hawk (Paudion haliatus carolinesis. Gmel). .

Common throughont the Province on Mainland and Island, including Queen Charlotte Islands.Their nest is a huge heap of sticks usually on the broken top of a tree.

Family bUbonide. Horned Owls, Etc.

Asio. (Brisson).

American Long-eared Owl (Asin wilsonianus, Less).

This bird is frequently seen abroad during the day, but is not remarkable for its voice or liabits. It is not common in the Province. Taken at Vancouvel Island, Chilliwhack and Okanagan. 
Short-eared Owl (Asio accipitrinus, Pall).

Common throughout the Province on Island and Mainland. Rather common near Victoria throughout the winter.

Srraum. (Saviguy).

*Northern Spotted Owl (Syrnium occidentalis caurinum, Merriam).

Chilliwhack.

Scotlaplex. (Swainson).

Great Grey Owl (Scotiaptcx ncbulosa, Forster).

Rare in the Province. Taken at Vernon, Stuart Lake and Chilliwlıack.

Criptograux. (Richmond).

Richardson's Owl (Cryptoglaux tengmalmi richardsoni, Bonap). Olianagan and Chilliwhack.

Saw-whet Owl (Cryptoglaux acadica, Gmel).

Not common on Vancouver Island; common in winter at Okanagan. Taken at Chilliwhack, Victoria and Okanagan.

Northwest Saw-whet Owl (Cryptoglaux acadica scotcea, Osgood). Queen Charlotte Islands.

\section{Megascops. (Kaup).}

Kennicott's Screech Owl (Megascops asio kennicottii, Elliot).

Abundant throughout the Province. Breeds in the neighbourhood of Victoria.

*Macfarlane's Screech Owl (Megascops asio macfarlanei, Brewst).

Southern portion of the Province, east of Cascade Mountains.

Puget Sound Screech Owl (Megascops asio saturatus, Brewster).

Bubo. (Dumeril).

*Great Horned Owl (Bubo virginianus, Gnel).

Chilliwhack and Victoria.

Western Horned Owl (Bubo virginianus pallescens, Stone).

Common on Vancouver Island and Mainland. Taken at Chilliwlıack and Okanagan. 


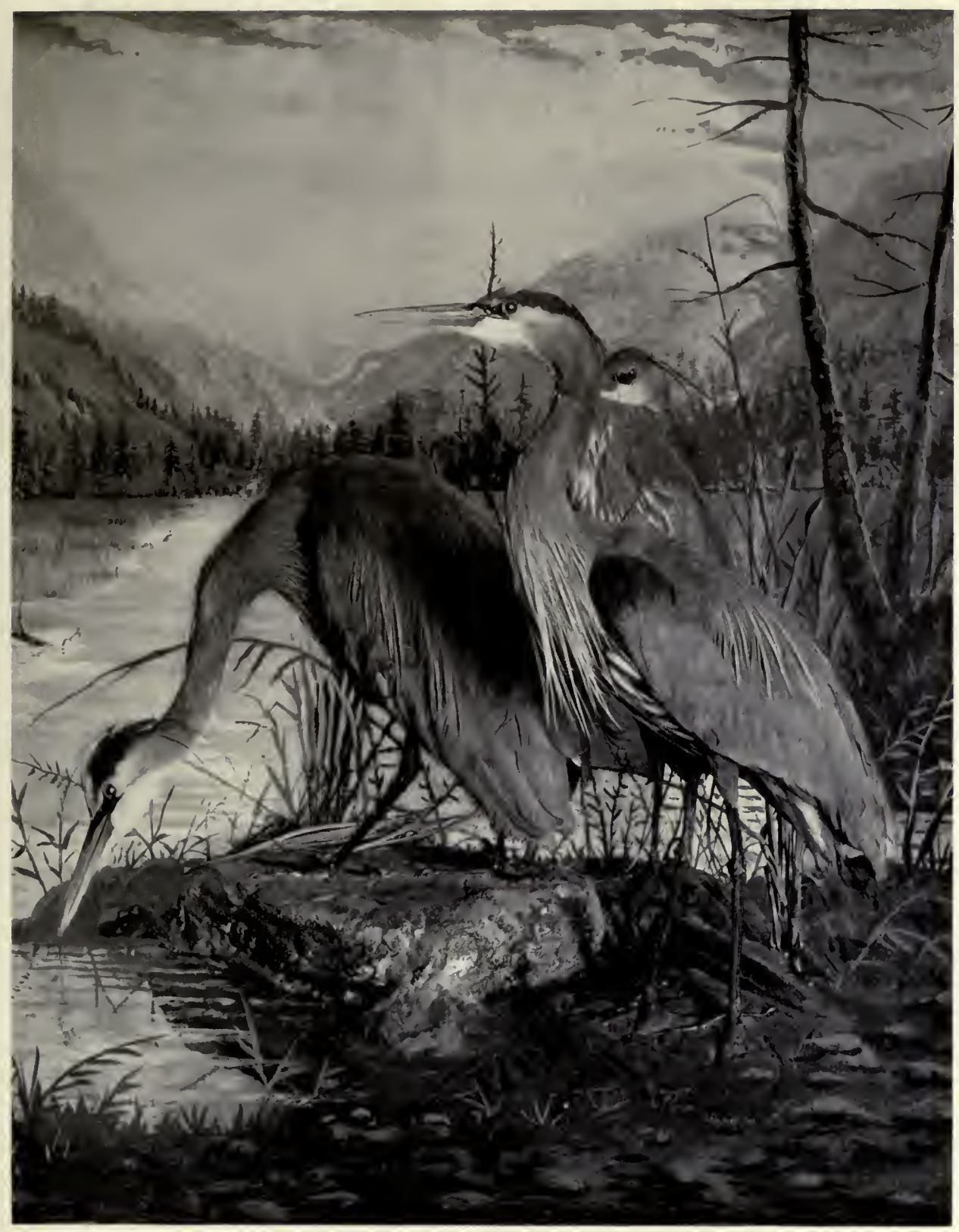

NORTH-WEST COAST HERON. ARDEA HERODIUS FANNINII (CHAPMAN). Group in Provincial Museum, Victoria, B. C. 

Arctic Horned Owl (Bubo virginianus arcticus, Swains).

Taken near Victoria and at Chilliwhack.

Dusky Horned Owl (Bubo virginianus saturatus, Ridgw).

An abundant resident in this Province; common on Vanconver Island; taken at Chilliwhack and Okanagan.

Nrctea. (Stejhens).

Snowy Owl (Nyctea nyctea, Limn).

A resident in the northern portions of the Province; south in winter to mouth of Fraser River, Chilliwhack and Okanagan; occasionally to Vancouver Island. Rare at Metlakatla.

Survia. (Duméril).

American Hawk Owl (Surnia ulula caparoch, Mull).

Not common, but fond throughout the southern part of the Province, from the coast to Okanagan. Rare on Vancouver Island. Taken at Victoria, Sardis, Grand Prairie and Vernon.

Speotyto. (Gloger).

Burrowing Owl (Speotyto cunicularia hypogaa, Bonap).

Not common in the Province. Taken at Chilliwhack and Vernon.

\section{Glaucidium. (Boie).}

California Pygmy Owl (Glaucidium gnoma californicum, Scl).

Common throughout the southern portions of the Province, including Vancouver Island.

\section{ORDER COCCYGES. CUCKOOS and KingFISHERS.}

Family CUCUlidie. Cuckoos.

CoccYzus. (Vieillot).

Western Yellow-billed Cuckoo, California Cuckoo (Coccyzus americanus occidentalis, Ridgw).

A regular summer resident in the south-western portion of the Province. The European Cnckoo never constructs a nest for itself, but drops its eggs in those of other bilds, and abandons them to their mercy and management. This conduct of the Cuckoo is so universally known, and so proverbial. that the whole tribe of 
Cuckoos have, by some inconsiderate people, been stigmatised as destitnte of all parental care and affection. Without attempting to account for this remarkable habit of the European species, far less to consider as an error what the wisdom of Heaven has imposed as a duty on the species, it must be remarked that the bird now before us builds its own nest, hatches its own eggs, and rears its own young; and in conjugal and parental affection seems nowise behind any of its neighbours of the grove. Both parents unite in providing food for the young. This consists for the most part of caterpillars, particularly such as infest trees. They are accused, with some justice, of sucking the eggs of other birds, like the Crow, the Blne Jay and other pillagers. They also occassionaly eat various kinds of berries; but from the circumstance of destroying such numbers of very noxious larva, they prove themselves the friends of the farmer, and are highly deserving of his protection. Breeds on Tancouver Islaud, near Victoria. Taken at Chilliwhack.

\section{Family alceDINide. Kúngfishers.}

Cerile. (Boie).

Belted Kingfisher (Ceryle alcyon, Linn).

Abundant throughout the Province. Breeds throughout its range.

\section{ORder PICI. WOODPECKers, Wrynecks, Etc.}

\section{Family PICIDA. Woonpeckers.}

Dryobates. (Boie).

Northern Hairy Woodpecker (Dryobates villosus leucomelas, Bodd).

Common on Maiuland, east of Cascade Mountains. Taken at Sicamous and Chilliwhack.

Harris's Woodpecker (Dryobates villosus harisii, And).

A common resident west of coast range, including Vancouver Island.

Cabanis's Woodpecker (Dryobates villosus hyloscopus, Cab). Okanagan. 
Queen Charlotte Woodpecker (Dryobatcs villosus picoideus, Osgood).

Queen Charlotte Islands.

Gairdner's Woodpecker (Dryobates pubescens gairdncri, Aud).

A common resident on Vancouver Island, coast of Mainland, and Lower Fraser Valley.

Batchelder's Woodpecker (Dryobates pubcscens homorus, Cab).

Common throughont the interior of the Province, along the C. P. R. at Ducks, and at Vernon. Taken at Chilliwhack and Okanagan.

\section{Xenopicus. (Baird).}

White-headed Woodpecker (Tcnopicus albolarvatus, Cass).

A rare bird in this Province. Found east of the Coast Range. Taken in the Similkameen Valley.

\section{Picoides. (Lacépède).}

Arctic, or Black-backed Three-toed Woodpecker (Picoides arcticus, Swains).

Found only east of Coast Range, where in some localities it is quite common. Taken at Okanagan.

*Alaskan Three-toed Woodpecker (Picoides americanus fasciatus, Baird).

Rare on Vancouver Island. Common in the spruce zone on the Coast Range.

*Alpine Three-toed Woodpecker (Picoides americanus dorsalis, Baird).

Mountains east of Cascades, and north to Cassiar.

$$
\text { Sphyrapicus. (Baird). }
$$

Red-náped Sapsucker (Sphyrapicus varins nuchalis, Baird).

Generally distributed east of Cascade Mountains throughout the Province. It is quite common at Ducks.

Red-breasted Sapsucker (Sphyrapicns ruber notkensis, Suckow).

Distributed along the coast. Not uncommon on Vancouver Island. Taken at Chilliwhack. 
*Williamson's Sapsucker (Sphyrapicus thyroidens, Cass).

Similkameen.

Ceophlqus. (Cabanis).

Northern Pileated Woodpecker (Ceophlœus pileatus abicticola, Bangs).

Common resident throughout the Province on Vanconver Island and Mainland through the interior to Okanagan. Scarce in the Cariboo District.

\section{Asyndesmus. (Coues).}

Lewis's Woodpecker (Asyndesmus torquatus, Wils).

The plumage of this remarkable Woodpecker is peculiar, both in texture and colour. No other specie of our country shows such a rich metallic iridescence, or such intense crimson, and in none is the plumage so curiously modified into a bristly character; unlike most species again the sexes are not certainly distinguishable. The young, however, differ very naterially, the under-parts being dull gray, only here and there slashed with red, the face lacking the crimson velvety pilous area, and the upper parts being much more lustrous. This fine species is chiefly a bird of the vast forests that clothe most of our mountain ranges with permanent verdure, with this limitation-its distribution is extensive. It is abundant throngh the interior of the Province, common at Chilliwhack, and a summer resident of Vancouver Island.

\section{Colaptes. (Swainson).}

Northern Flicker (Colaptes auratus luteus, Bangs).

A rare bird of this Province, but is found on Vancouver Island and east to the Rocky Mountains.

Red-shafted Flicker (Colaptes cafer collaris, Vigors).

Common east of Cascade Mountains, through the interior, at Ducks, Sicamous and Okanagan.

North-western Flicker (Colaptes cafer saturatior, Ridgw).

Abundant resident west of Cascade Mountains; very common on Vancouver Island. 


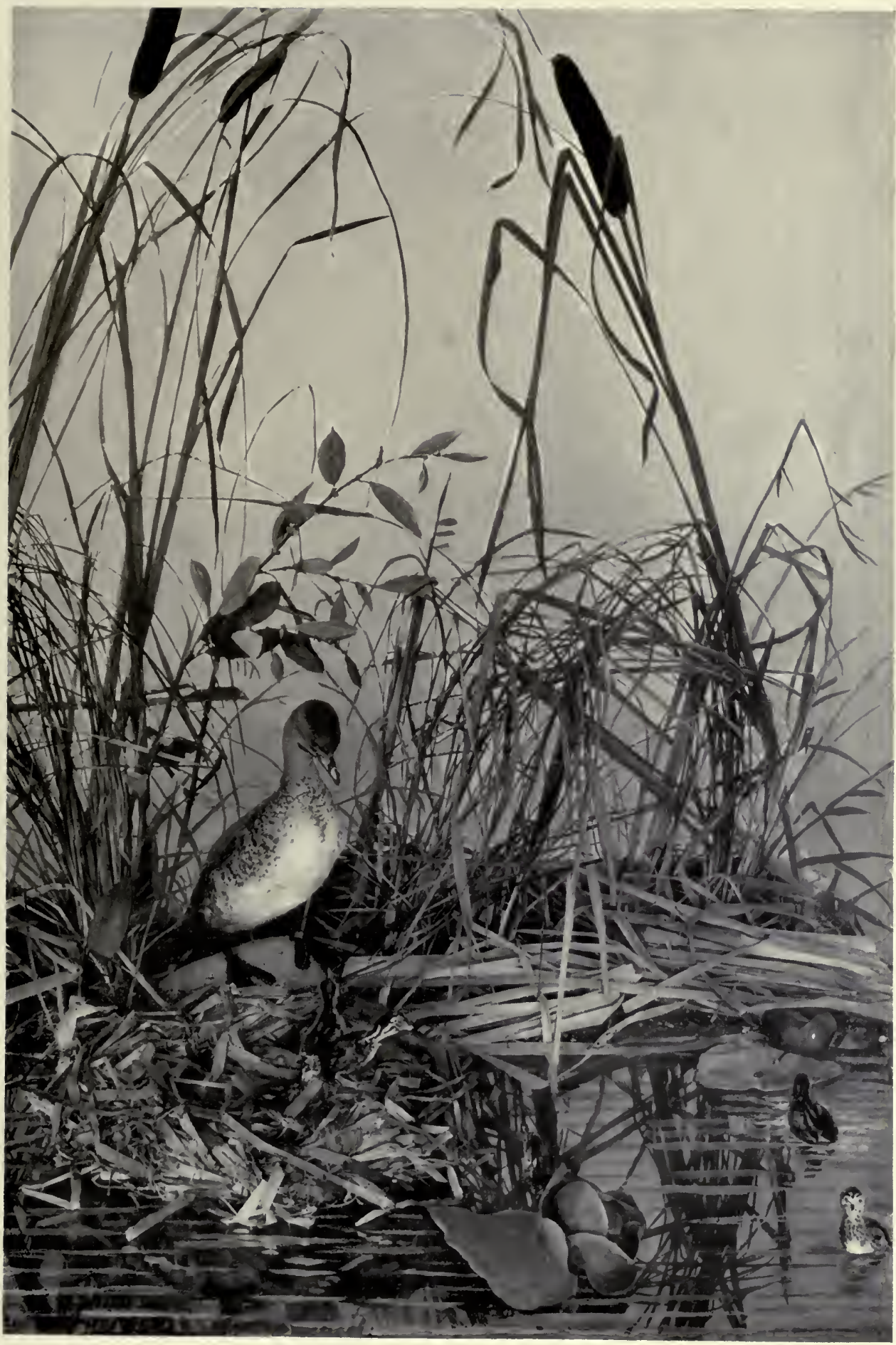

PIED-BILLED GREBE. PODILYMBUS PODICEPS (LINN.). Group in Provincial Museum, Vietoria, B. C. 

Order MACROCHIRES. GoATsuckers, Swifts, Etc.

\section{Family Caprimelgide. Goatsuckers.}

Phalanoptilus. (Ridgway).

Poor-will (Phalemoptilus nuttallii, And).

Southern interior portions of Province from Kamloops through the Okanagan. Summer resident.

Chomenules. (Swainson).

*Nighthawk (Chordeiles virginianus, Gmel).

East of Cascade Mountains.

Western Nighthawk (Chordeiles virginianus henryi, Cass).

A summer resident west of Cascade Mountains. Abundant on Vancouver Island.

\section{FAMILY MICROPODIDA. SwIFTs. \\ Cypseloides. (Streubel).}

Black Swift (Cypseloides niger borealis, Ridgw).

Common near Victoria during migration. Taken at Chilliwhack and Okanagan. Breeds in mountains back of Chilliwhack and in the neighbourhood of Comox.

Chatura. (Stephens).

Vaux's Swift (Chatura vanxii, Towns).

A summer resident on Vancouver Island and Mainland. Very common near Sicamous.

Aeronautes. (Hartert).

White-throated Swift (Aëronautes melanoleucus, Baird).

Keremeos, Okanagan.

\section{Family Trochilide. Humalagbirds. \\ Trochilus. (Limnaus).}

Black-chinned Hummingbird (Trochilus alexandri, Bourc and Muls).

Chilliwhack. 
Selasphorus (Swainson).

Red-backed Rufous Hummingbird (Selasphorus rufus, Gmel).

Vancouver Island and Okanagan; common at Metlakatla.

*Green-backed Rufous Hummingbird (Selasphorus alleni, Hensh).

Eastern, Cascades and Rocky Mountains.

$$
\text { Stellula. (Gould). }
$$

Calliope Hummingbird (Stellıla calliope, Gould).

East and west of Cascade Mountains.

\section{Order PASSERES. Perching Birds.}

Fanily TyRanNiDA. Tyrant Flycatchers.

Trrannus. (Cuvier).

Kingbird (Tyrannus tyrannus, Linn).

A common summer resident on the Mainland at Chilliwhack, Sardis, Ducks, and Vernon, and as far north as Port Simpson. Rare on Vancouver Island.

Gray Kingbird (Tyrannus dominicensis, Gmel).

Cape Beale, B. C.

Arkansas Kingbird (Tyrannus verticalis, Say).

A common resident on the Mainland. Common at Chilliwhack, Ducks and Okanagan. Rarely west to Vancouver Island.

$$
\text { SaYornis. (Bonaparte). }
$$

Say's Phoebe (Sayornis saya, Bonap).

A summer resident on Vancouver Island and Mainland. Taken at Chilliwhack and Okanagan.

\section{Contopus. (Cabanis).}

Olive-sided Flycatcher (Contopus borealis, Swains).

A summer resident on Vancouver Island and Mainland. Taken at Chilliwhack and Okanagan. 
Western Wood Pewee (Contopus richardsonii, Swains).

A common summer resident on Vancouver Island and Mainland. Very common at Sicamous.

\section{Empidonax. (Cabanis).}

Western Flycatcher (Empidonax difficitis, Baird).

A common summer resident west of Cascade Mountains on Mainland and on Vancouver Island. Also at Skidegate, Queen Charlotte Islands.

Traill's Flycatcher (Empidonax trailli, Aud).

Vancouver Island and Mainland, at Sicamous and Vernon; also Clilliwhack and Okanagan.

Hammond's Flycatcher (Empidonax hammondi, Xantus). Island.

Summer resident, chiefly on the Mainland. Taken Vancouver

Wright's Flycatcher (Empidonax wrightii, Baird).

Summer resident. Taken at Chilliwhack and Okanagan.

Family alaUdide. Larks.

OTocoris. (Bonaparte).

Pallid Horned Lark (Otocoris alpestris leucolama, Coues).

Common in spring and autumn on Vancouver Island. Taken at Clover Point, near Victoria; also at Chilliwhack and Okanagan.

Streaked-Horned Lark (Otocoris alpcstris strigata, Hensh).

Spring and autumn migrant on Vancouver Island. Taken at Chilliwhack. West of Cascades, Burrard Inlet, Vancouver Island and Port Simpson.

Dusky Horned Lark (Otocoris alpestris merilli, Dwight).

Chiefly east of Cascades. Never known to be taken on Vancouver Island. Taken at Chilliwhack, Okanagan and Osoyoos. 
Fanily CORVIDAE. Crows, Jays, Magpies.

PicA. (Brisson).

American Magpie (Pica pica hudsonica, Sab).

A common resident on the Mainland. rarely west to Vancouver Island. Breeds in the interior of the Mainland, east of Cascade Mountains. It is a social bird, although not gregarious, being usually found in pairs or small parties of from three to six or eight, but quite often goes alone. It is very voracious, living upon seeds, carrion, insects, etc., and being especially fond of the eggs and young of other birds, of which it destroys very great quantities. It is easily caught and tamed, even when old, and soon becomes very cumning and mischievous, exhibiting the same traits as the crow, and, like that bird, is said to imitate the human roice with some aptitude. It has almost an infinite variety of notes, some low, gurgling and musical, some harsh and discordant, others sqneaky and grating. It is very noisy at times, and quite silent at others, when engaged in robbing bird's nests or foraging near dwelliugs or barns. It is not a shy bird, but if frequently shot it soon learns to keep out of range.

\section{Cranocitta. (Strickland).}

Steller's Jay (Cyanocitta stelleri, Gmel).

An abundant resident west of Coast Range on Mainland and Vancouver Island throughout the year.

Black-headed Jay (Cyanocitta stelleri annectens, Baird).

Common in the interior from the Cascades east down through the Okanagan. Taken at Chilliwhack.

*Queen Charlotte Jay (Cyanocitta stellcri carlotte, Osgood). Queen Charlotte Islands.

Perisoreus. (Bonaparte).

Rocky Mountain Jay (Perisoreus canadensis capitalis, Ridgw).

East of Cascade Mountains. Taken at Okanagan and in the Cariboo District.

Oregon Jay (Perisorcus obscums, Ridgw).

An abundant resident west of Cascades on the Mainland; but not as numerous on Vancouver Island. 


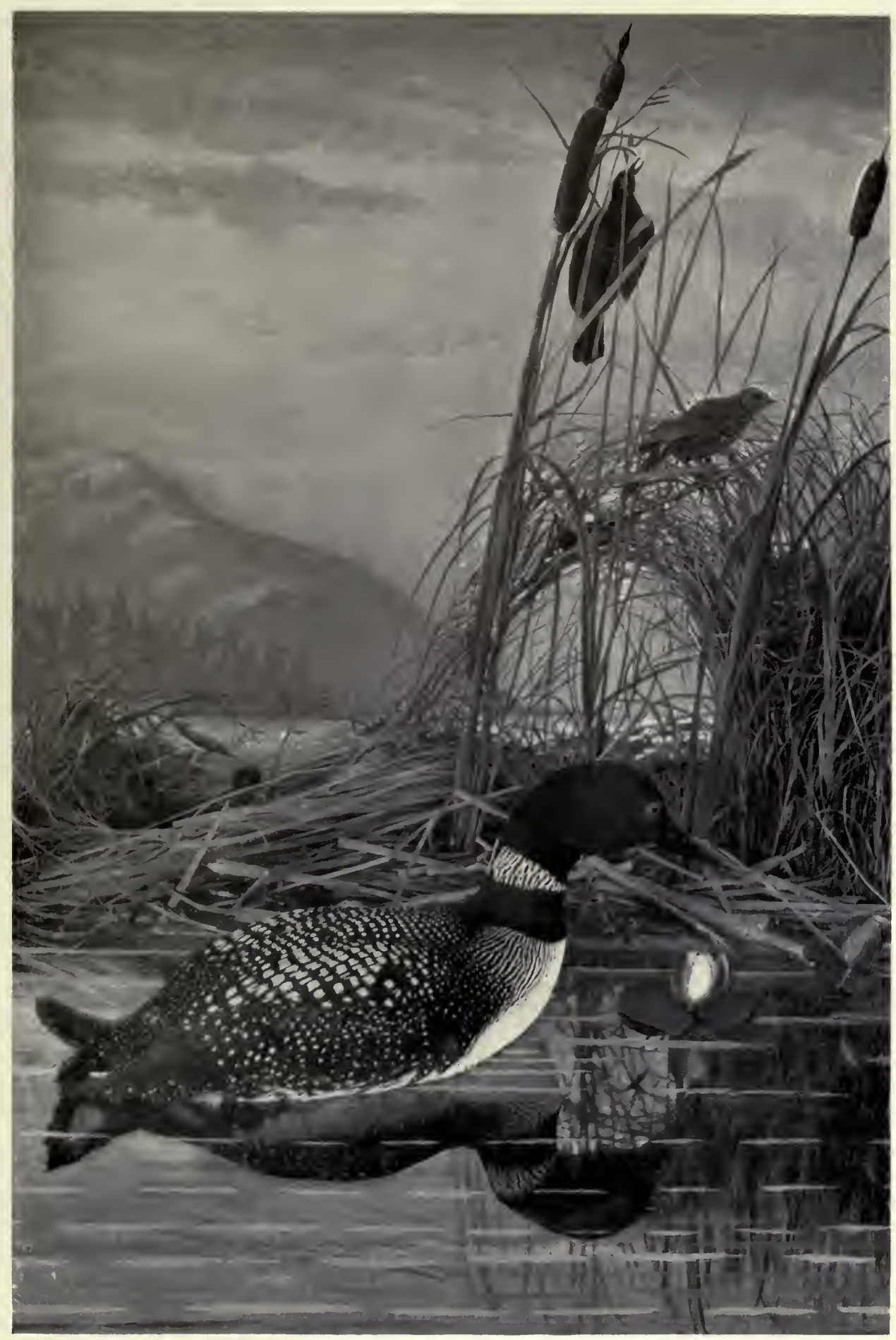

GREAT NORTHERN DIVER. GAVIA IMBER (GUNN.). Group in Provincial Museum, Victoria, B. C 

* Gray Jay (Pcrisoreus obscurus griscus, Ridgw).

East of the Coast and Cascade Ranges.

Corres (Linnaeus).

Northern Raven (Corvus corax principalis, Ridgw).

A resident throughout the Province: more common on the Const Taken at Chilliwhack and Okanagan.

American Crow (Corvus brachyrhynchos, Brehm).

Common east of Coast Range. Chilliwhack and Okanagan.

Northwest Crow (Corvus caurinus, Baird).

An abundant resident west of Cascade Mountains on Main!anrl and Vancourer Island, and at Skidegate, Queen Charlotte Islands.

\section{Nécifraga. Brisson).}

Clarke's Nutcracker (Nucifraga columbiana, Wils).

A common resident on the Mainland. chiefly east of Coast Range; rare on Vancourer Island.

$$
\text { Cranocephalus. (Bonaparte). }
$$

*Blue Crow, Pinion Jay (Cyanocephalus cyanocephalus, Wied).

Rocky Mountain region to the Pacific Coast Ranges.

Fanily ICTERid E. Blackbirds, Orioles, Etc.

Dolichoryx. (Swainson).

*Bobolink (Dolichonyx oryzitorus, Linn).

East and west of Cascade Mountains. Chilliwhack.

$$
\text { Molothrus. (Swainson)... }
$$

Cowbird (Molothrus ater, Bodd).

A summer resident. Fairly common in the neighbourhood of Ducks, on C. P. R., and Okanagan. Rare on Vancourer Island and Metlakatla. Taken near Victoria and Chilliwhack.

\section{Xaxthocephales. (Bonaparte).}

\section{Yellow-headed Blackbird (Yanthocephalus xanthocephalus, Bonap).}

A rare summer resident on the Mainland. Taken at Chilliwhack. 
Ageliaus. (Vieillot).

San Diego Redwing (Agcliaus phœniceus ncutralis, Ridgw).

East of Cascades. Taken at Vernon.

Northwestern Redwing (Ageliaus phœniceus caurinus, Ridgw).

Common west of Cascades on Mainland and Vancourer Island. Found throughout the year near Victoria.

\section{Sturnella. (Vieillot).}

Western Meadowlark (Sturnella magna neglecta, Aud).

Is an abundant resident on Mainland and Vancouver Island; east and west of Cascades.

\section{ICTERus. (Brisson).}

Bullock's Oriole (Icterus bullocki, Swains).

A fairly common summer resident, chiefly east of Cascades. Breeds along the valley of the Thompson and in the Okanagan near Vernon, also at Chilliwhack.

\section{Euphagus. (Cassin).}

Rusty Blackbird (Euphagus carolinus, Muller).

Rare. Metlakatla.

Brewer's Blackbird (Euphagus cyanocephalus, Wagler).

Common generally on the Mainland, also in Lower Fraser Valley, Grand Prairie, south side of Thompson River, down into the Okanagan country. Ireeding in suitable localities. Not common on Vancouver Island. Taken near Victoria.

Family Fringillide. Finches, Sparrows, Etc.

Hesperiphona. (Bouaparte).

Western Evening Grosbeak (Hesperiphona vespertina montana, Ridgw).

Chiefly on the Mainland. West in winter to Vancouver Island and Lower Fraser Valley. Taken at Chilliwhack and Okanagan.

Pinicola. (Vieillot).

Alaskan Pike Grosbeak (Pinicola enucleator alascensis, Ridgw).

Mainland east and west of Cascade Mountains, including Vancouver Island. Common in winter in the neighbourhood of Clinton. 


\section{Carpolacus. (Kanp).}

California Purple Finch (Carpodacus purpurcus californicus, Baird).

An abundant summer resident west of Cascades. Quite a number winter on Vancouver Island.

Cassin's Purple Finch (Carpodacus cassini, Baird).

Tolerably common east of Cascades to Rocky Mountains.

L_oxi. (Limnaeus).

American Crossbill (Loxia curvirostra minor, Brehm).

An abundant resident throughout the Province, Island and Mainland.

White-winged Crossbill (Loxia lencoptera, Gmel).

An abundant resident, chiefly on the Mainland, occasionally west to Vancouver Island.

\section{Leucostrcte. (Swainson).}

Gray-crowned Leucosticte (Leucosticte tephrocotis, Swains).

Rocky Mountain District. In winter occasionally west of Cascades. Taken as far west as Chilliwhack.

Hepburn's Leucosticte (Lencosticte tephrocotis littoralis, Baird).

Common on Mainland from coast to Rocky Mountains. Breeds above timber line in the interior.

\section{Acanthis. (Bechstein).}

Hoary Redpoll (Acanthis hornemannii exilipes, Coues).

Taken at mouth of Quesnel River and Chilliwhack.

Redpoll (Acanthis linaria, Linn).

Found throughout the Province; more abundant in the Rocky Mountain District. West in winter to Vancouver Island.

$$
\text { Astrigalinus. (Cabanis). }
$$

Willow Goldfnch (Astragalinus tristis salicamans, Grinnell). Taken at Okanagan. 
Spinus. (Koch).

Pine Siskin (Spinus pinus, Wils).

An abundant resident throughout the Province. Breeds throughout its range.

Passer. (Brisson).

*House Sparrow (Passer domesticus, Linn).

Quite common in the cities along the Coast.

Passerina. (Vieillot).

Snowflake (Passerina nivalis, Linn).

Not common on Vancouver Island; more abundant east of Cascades on the Mainland.

Calcarius. (Bechstein).

Lapland Longspur (Calcarius lapponicus, Linn).

The Province at large but nowhere common. Taken at Victoria, Chilliwhack, Burrard Inlet, Okanagan, Port Simpson and Metlakatla.

$$
\text { RhyNChophanes. (Baird). }
$$

McGown's Longspur (Rhynchophanes mccounii, Lawr). Chilliwhack.

Pocectes. (Baird).

Western Vesper Sparrow (Poœcetos gramineus confinis, Baird).

Interior portions of the Mainland east of Cascades, and in the Okanagan.

Oregon Vesper Sparrow (Poœcetos gramineus affnis, Miller). West of Cascades, including Vancourer Island.

Passerculus. (Bonaparte).

Sandwich Sparrow (Passerculus sanduichensis, Gmel).

An abundant summer resident west of Cascades on the Main. land, also Vancourer Island. Taken at Okanagan.

Western Savanna Sparrow (Passerculus sandwichensis alaudinus, Bonaparte).

A common summer resident on the Coast, including Vancouver Island. 


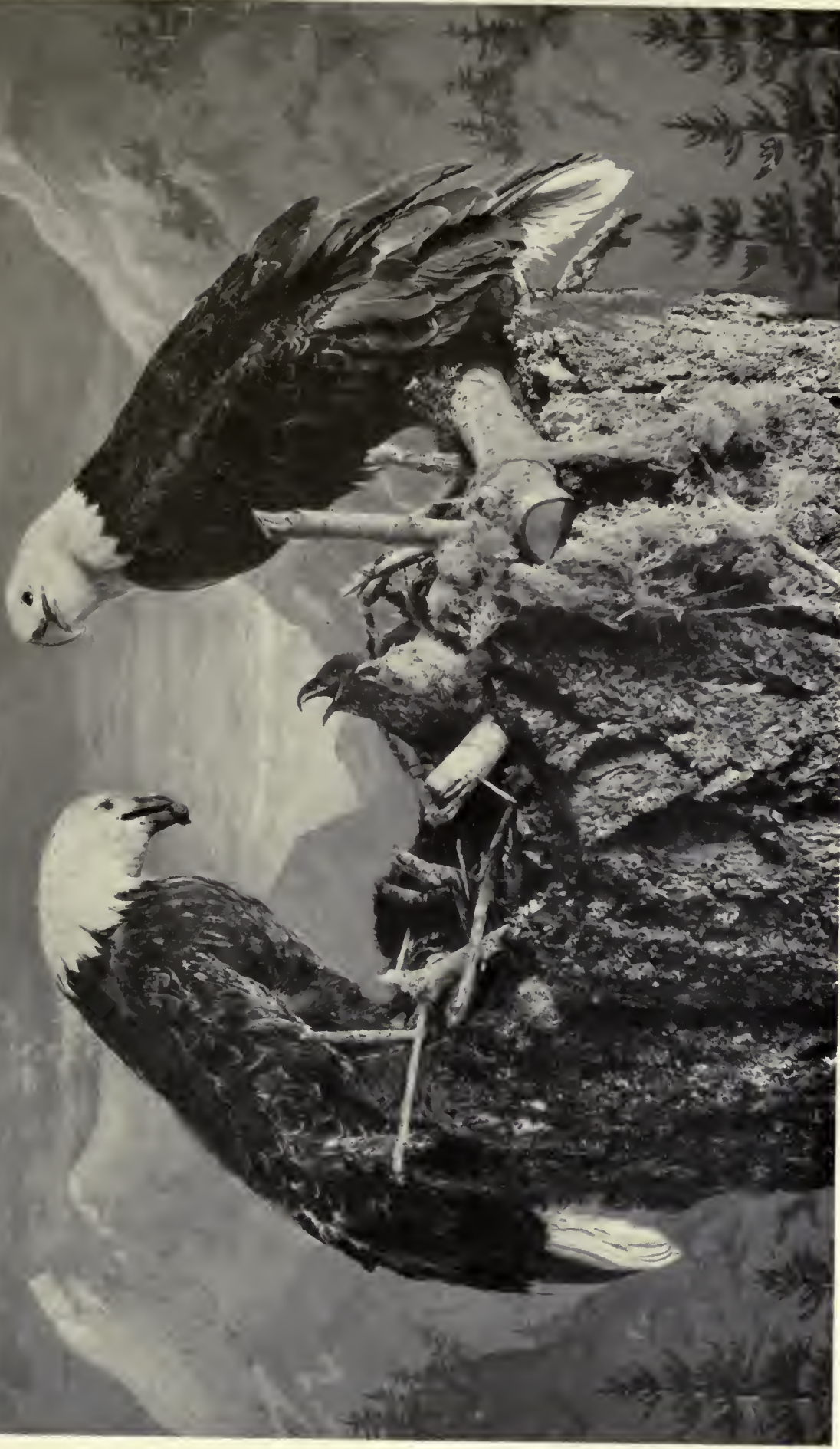



Cotrurniculus. (Bonaparte).

Western Grasshopper Sparrow (Coturniculus savannarum bimaculatus, Swainson).

A common summer resident in the Okanagan near Vernon.

\section{Chondestes. (Swainson).}

Western Lark Sparrow (Chondestes grammacus strigatus, Swains).

Interior southern portions of the Mainland, from Chilliwhack east through the Okanagan.

\section{ZoNotrichia. (Swainson).}

Harris's Sparrow (Zonotrichia querula, Nutt).

Taken at Cadboro Bay, near Victoria, Comox and Sumas.

Gambel's Sparrow (Zonotrichia leucophrys gambelii, Nutt).

Common. Mainland, east of Coast Range, east to Okanagan.

Intermediate Sparrow (Zonotrichia lencophrys intermedia, Ridgw).

Found throughout British Columbia.

Golden-crowned Sparrow (Zonotrichia coronata, Pallas).

Abundant during migrations on the Coast. Taken at Chilli whack and Okanagan.

\section{Spizella. (Bonaparte).}

Western Tree Sparrow (Spizella monticola ochracea, Brewst).

Taken at Chilliwhack and Okanagan; also at Victoria.

Western Chipping Sparrow (Spizella socialis arizone, Coues).

An abundant summer resident east and west of Cascades. Breeds near Victoria where a number remain throughout the winter.

Clay-coloured Sparrow (Spizella pallida, Swains).

Carpenter's Mountain, 150-Mile House, Cariboo.

Brewer's Sparrow (Spizella breweri, Cass).

Eastern Cascades and Rocky Mountain Districts, Similkameen and Okanagan. 
Juxco. (Wagler).

*Slate-coloured Junco (.Junco hyemalis, Linn).

Chilliwhack.

Oregon Junco (Junco hyemalis oreganus, Townsend).

Abundant resident west of Cascades; also Vancouver Island.

*Shufeldt's Junco (Junco hyemalis shufcldti, Coale).

Breeding from interior British Columbia (Stuart's Lake) east to Rocky Mountains, south to Vancouver Island.

\section{MelosipZa. (Baird).}

Rusty Song Sparrow (Melosipza cinerea morphna, Oberh).

An abundant resident throughout the Province. Breeds on Vancouver Island and Mainland.

Sooty Song Sparrow (Melosipza cinerea rufina, Bonap).

Abundant along the coast of Mainland and north-west Vancouver Island; also common at Skidegate, Queen Charlotte Islands.

Forbush's Sparrow (Melosipaa lincolnii striata, Brewst).

Comox, Chilliwhack and Victoria.

$$
\text { Passerella. (Swainson). }
$$

Townsend's Sparrow (Passerella iliaca unalschcensis, Gmel).

A common summer resident west of Cascades. Taken on Vancouver Island, where a few remain all winter.

Slate-coloured Sparrow (Passerella iliaca schistacca, Baird).

Southern portion of Mainland east of Cascades, Sicamous and Okanagan.

Sooty Fox Sparrow (Passerella iliaca fuliginosa, Ridgw).

Vancouver Island.

$$
\text { Pipilo. (Vieillot). }
$$

Spurred Towhee (Pipilo maculatus megalonyx, Baird).

East of Cascades and through the Okanagan. 
Oregon Towhee (Pipilo maculatus orcgonus, Bell).

An abundant resident west of Cascades. Breeds on Vancouver Island and Mainland.

$$
\text { Zamelonia. (Cones). }
$$

Black-headed Grosbeak (Zamelodia melanocephala, Swains).

A summer resident on Vanconrer Island, and east and west of Cascades. Taken at Chilliwhack.

$$
\text { Cranospiza, (Baird). }
$$

Lazuli Bunting (Cyanospiza amona, Say).

A summer resident, chiefly east of Cascades. Rare on Vancouver Island. Seen at Chilliwhack and near Vernon.

\section{Family TANAGRIDE. Tanagers.}

Piranga, (Vieillot).

Louisiana Tanager (Piranga ludoviciana, Wils).

An abundant summer resident throughont the Province.

Family HiRundinide. Swallows.

$$
\text { Progne. (Boie). }
$$

Purple Martin (Progne subis, Linn).

A common summer resident, chiefly in the cities along the Coast. West of Cascades.

$$
\text { Perrochelidon. (Cabanis). }
$$

Cliff Swallow (Petrochelidon lunifrons, Say).

Common summer resident on the Mainlaud, east and west of Cascades, Chilliwhack, Okanagan and Cariboo Road.

$$
\text { Hiruxdo. (Linn). }
$$

Barn Swallow (Hirundo erythrogastra, Bodd).

Abundant summer resident throughout the Province; including Vancouver Island and Queen Charlotte Islands.

$$
\text { Tachycheta. (Cabanis). }
$$

White-bellied Swallow (Tachycincta bicolor, Vieill).

An abundant summer resident east and west of Cascades. 


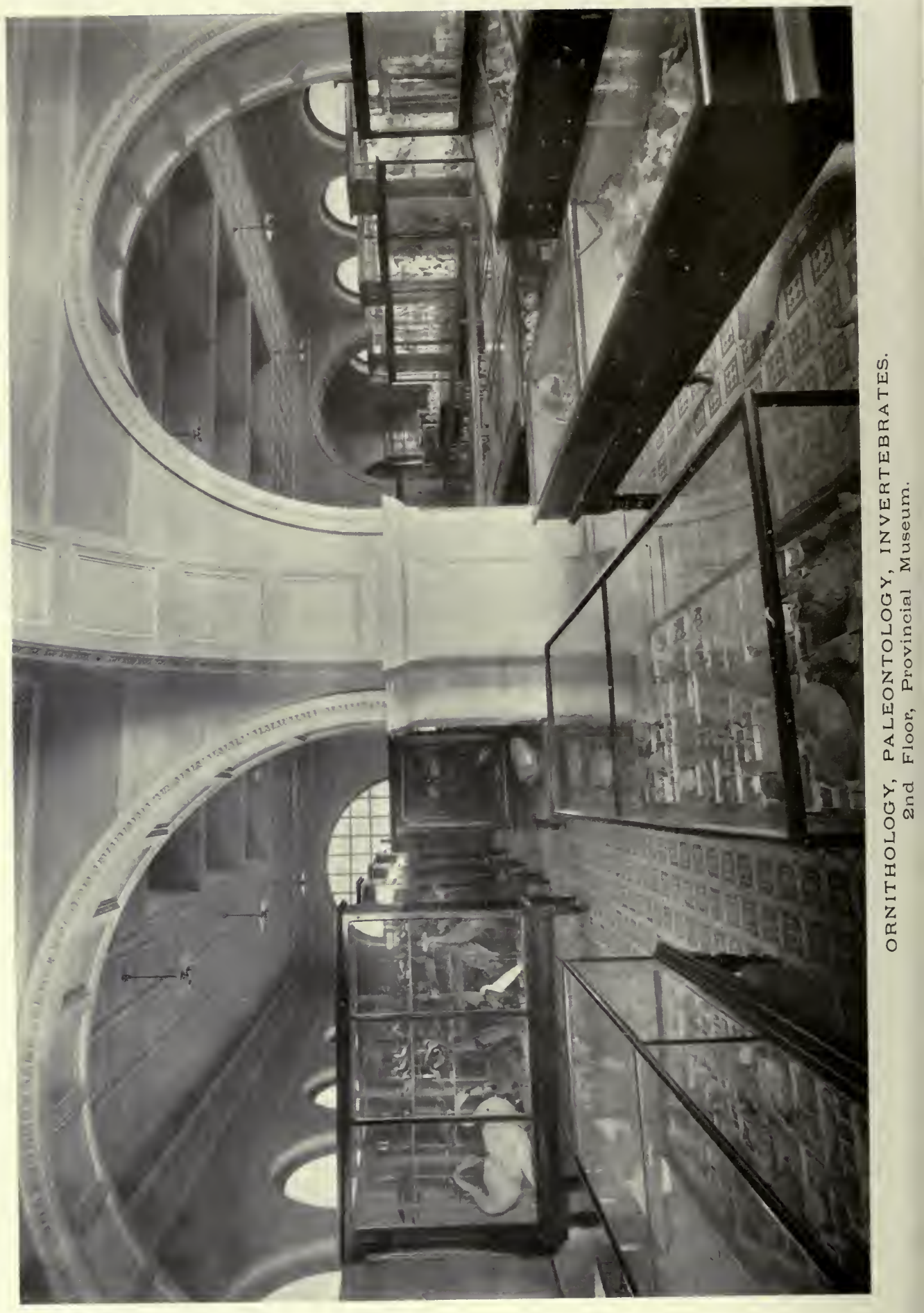


Northern Violet-green Swallow (Tachycineta thalassina lepida, Mearns).

An abundant summer resident throughout the Province east and west of Cascades.

$$
\text { Riparia. (Forester). }
$$

Bank Swallow (Riparia riparia, Linn).

An abundant summer resident, chiefly east of Cascades north to Cariboo District. Very conmon from Sicamous down through the Okanagan. Taken at Chilliwhack.

$$
\text { Stelghopteryx. (Baird). }
$$

Rough-winged Swallow (Stelgitlopteryx serripennis, Aud).

A common resident throughout the Province.

\section{Family ampelide. Waxwings.}

\section{Ampelis. (Linnæus).}

Bohemian Waxwing (Ampelis garrulus, Linn).

An abundant resident, chiefly east of Cascades. A winter visitant to the Coast and Vanconver Island.

Cedar Bird (Ampelis cedrorum, Vieill).

A common summer resident throughont the Province

$$
\text { Family LanitDa. Shrikes. }
$$$$
\text { Laxius. (Linnæus). }
$$

Northern Shrike, Butcher Bird (Lanius borealis, Vieill).

Not common, but found distributed throughout the Province. Found throughoụt the winter on the Coast.

*White-rumped Shrike (Lanius ludovicianus excubitorides, Swains).

Chilliwhack and Victoria.

\section{Fanili Vireonida. Vireos. \\ Vireo. (Vieillot).}

Red-eyed Vireo (Vireo olivaceus, Linn).

Distributed over the southern portions of the Province; also Vancouver Island. A summer resident. Taken at Chilliwhack and Okanagan. 
Western Warbling Vireo (Vireo gilvus suainsonii, Baird).

Common summer resident west of Rocky Mountains to Pacific.

Cassin's Vireo (Vireo solitarius cassinii, Xantus).

A summer resident east and west of Cascades, including Vancourer Island.

Anthony's Vireo. Dusky Vireo(Vireo huttoni obscurus, Anthony). Resident on Vancouver Island and Mainland.

\section{Family MNiotilTiDA. Wood Warblers.}

Helinthopila. (Ridgway).

Calaveras Warbler (Helminthopila ruficapilla gutturalis, Ridgw). Rocky Mountains to Pacific. A summer resident. Common in the Okanagan.

Orange-crowned Warbler (Helminthophila celata, Say).

A common summer resident east of Cascades.

Lutescent Warbler (Helminthophila celata lutescens, Ridgw).

An abundant summer resident, chiefly west of Cascades and along the coast of Mainland and Vancouver Island.

Tennessee Warbler (Helminthophila peregrina, Wils).

Taken at 150-Mile House, Cariboo.

Dendroica. (Gray).

Alaskan Yellow Warbler (Dendroica estiva rubiginosa, Pallas).

An abundant summer resident throughout the Province from Rocky Mountains to the Pacific.

Myrtle Warbler (Dendroica coronata, Linn).

An abundant summer resident on Vancouver Island and Mainland, chiefly west of Cascades. Rare at Metlakatla. Taken in Okanagan.

Audubon's Warbler (Dendroica auduboni, Towns).

An abundant summer resident throughout the Province from Vancouver Island east to the Rocky Mountains. 
* Magnolia Warbler (Dendroica maculosa, Gmel).

Okanagan.

Black-throated Gray Warbler (Dendroica nigrescens, Towns).

Not common. A summer resident west of Cascades, but chiefly along the Coast. Taken at Chilliwhack.

Townsend's Warbler (Dendroica townsendi, Townsend).

Not common, but found distributed throughout the Province, chiefly west of Cascades, including Vancouver Island and Queen Charlotte Islands.

*Hermit Warbler. Western Warbler (Dendroica occidentalis, Townsend).

A summer resident, chiefly west of Cascade Range.

Seiurus. (Swainson).

Grinnell's Water-thrush (Seiurus noveboracensis notabilis, Ridgw).

Taken at Ducks, C. P. R.; and Quesnel.

Geothlypis. (Cabanis).

Macgillivary's Warbler (Geothlypis tolmiei, Towns).

A common summer resident throughout the Province.

Western Yellow-throat (Geothlypis trichas occidentalis, Brewst).

A common summer resident throughout the Province.

Pacific Yellow-throat (Geothlypis trichas arizela, Oberh).

Summer resident in the southern portions of the Mainland and Vancouver Island.

ICTERIa. (Vieillot).

Long-tailed Chat (Icteria virens longicauda, Lawr).

Summer resident in the southern portions of the Province from Sumas east to Okanagan, south of Ashcroft.

Wilsonia. (Bonaparte).

*Wilson's Warbler (Wilsonia pusilla, Wils).

Vancouver Island and Mainland, east and west of Cascades. 
Pileolated Warbler (Wilsonia pusilla pileolata, Pall).

A common summer resident on Vancouver Island and Mainland.

Golden Pileolated Warbler (Wilsonia pusilla chryseola, Ridgw). A summer resident, New Westminster and Monnt Lehman:

Setophaga. (Swainson).

American Redstart (Setophaga ruticilla, Linn).

Found throughont the interior of the Province from Barkerville south to Okanagan, chiefly east of and accidentally west of, Cascades. Taken at Chilliwhack.

\section{Family motacilaide. Wagtails and Pipits}

Antruus. (Berdistein).

American Pipit (Anthus ponsilvanicus, Lath).

Very abundant during migration east and west of Cascades. Found throughont some winters on Vanconver Island.

Family CINClitie. Dippers.

Cinclus. (Bechstein).

American Dipper (Cinclus mexicanus, Swains).

Common throughout the Province in suitable localities.

Fanitiy 'TROglom Y'TIDA. Wrans.

Galeoscoptes. (Cabanis).

Catbird (Galeoscoptes carolinensis, Linn).

A common summer resident east and west of Cascades. Rare on Vanconver Island.

Salpinctes. (Cabanis).

Rock Wren (Salpinctes obsoletus, Say).

Common east of Cascades; rarely west to the Coast. Chilliwhack and Burrard Inlet.

Thryomanes. (Sclater).

Vigor's Wren (Thryomanes bewickii spilurus, Vig).

A common summer resident west of Cascades. Found throughtout the winter on Vancouver Island. 


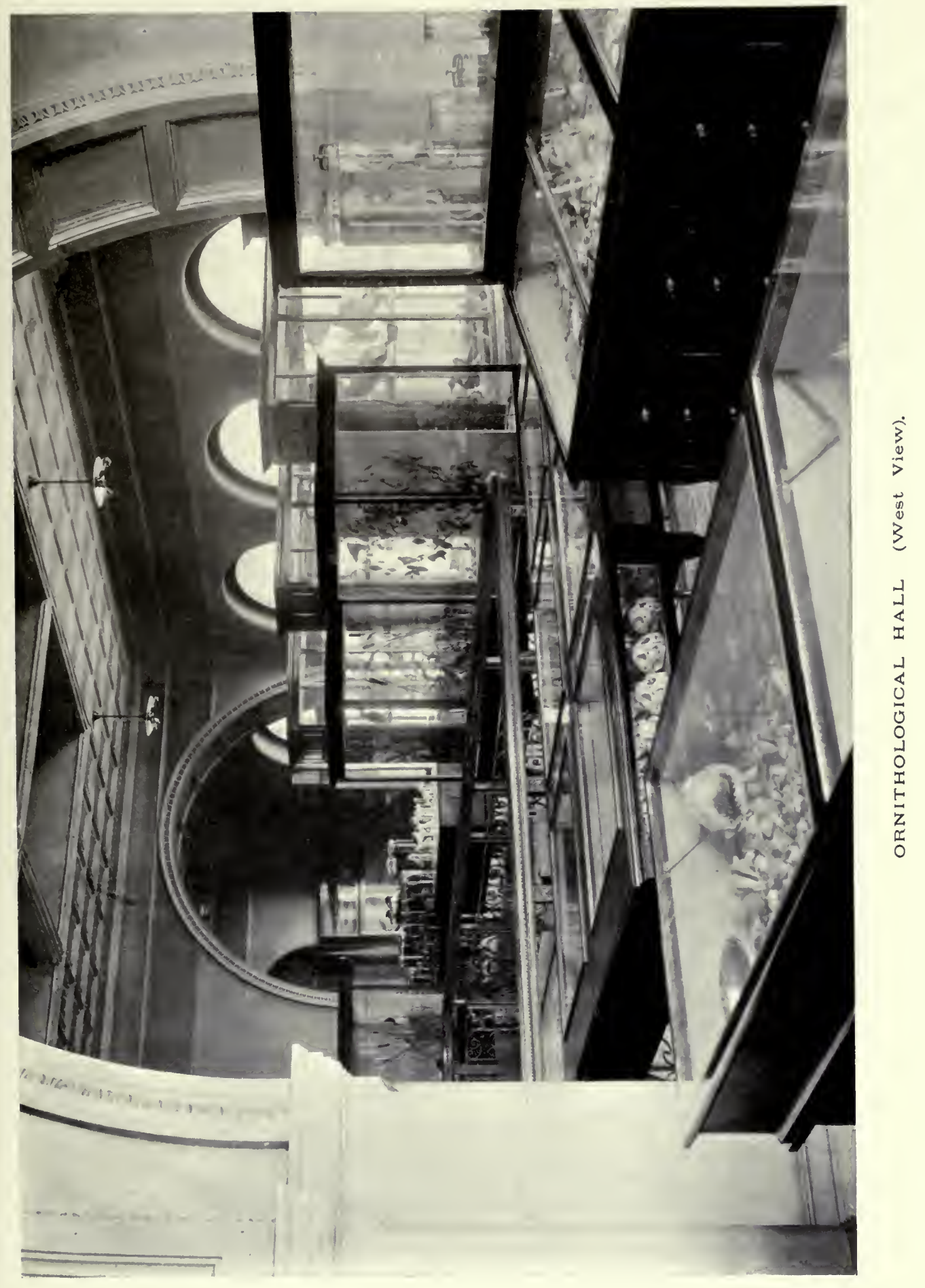


Troglonytes. (Vieillot).

Parkman's Wren (Troglodytes aëdon parkmanii, Aud).

A common summer resident east and west of Cascades, including Vancouver Island.

\section{Olbionchilus. (Oberholser).}

Western Winter Wren (Olbiorchilus hiemalis pacificus, Baird).

An abundant resident east and west of Cascades, including Vancouver Island.

Telanatodytes. (Cabanis).

Tule Wren (Tclmatodytes palustris paludicola, Baird).

Abundant east of Cascades, from the lakes along the Cariboo Road, south through the Okanagan. Taken at Chilliwhack.

\section{Family CERThiIdA. Creepers.}

Certhia. (Linnæus).

Rocky Mountain Creeper (Certhia familiaris montana, Ridgw).

Southern portion of east of Cascades. Okanagan.

California Creeper (Certhia familiaris occidentalis, Ridgw).

Common on Vancouver Island. East and west of Cascades on the Mainland.

Family SitTide. Nuthatches.

Sitta. (Linnæus).

Slender-billed Nuthatch (Sitta carolinensis aculeata, Cass).

Common east of Cascades from Ashcroft south through the Okanagan. Common near Shuswap.

Red-breasted Nuthatch (Sitta canadensis, Linn).

Common east and west of Cascades. Found throughout the winter on Vanconver Island.

Pygmy Nuthatch (Sitta pygmaa, Vig).

East of Cascades in the south-eastern portions of the Province. Common at Grand Prairie. 
Family PARIDA. Thamee or Chichades.

Parus. (Linnacus).

Long-tailed Chickadee (P'arus atricapillus septentriomalis, Harris).

Common east of Cascades, from Cornwall's south to Okanagan.

Oregon Chickadee (Purus atricapillus occidcntalis, Baird).

A common resident west of Cascades.

Mountain Chickadee (Parus gambeli, Ridgw).

East of Cascades to Rocky Mountains and south through Okanagan.

Columbia Chickadee (Parus hudsonicus columbianus, Rhoads).

East of Cascades to Rocky Mountains from Cassiar District south to Okanagan.

Chestnut-backed Chickadee (Parus rufescens, Towns).

An abundant resident, chiefly west of Cascades, Vancouver Island and Queen Charlotte Islands. Taḱen at Arrow Lake.

Family CHamaina. Tús and Busil-tits.

Psalitriparus. (Bonaparte).

Least Bush-tit (Psaltriparus minimus, 'lowns).

Rare. Taken at Sumas.

Fanily SYIVIIDA. Warblers, Kinglets.

Regulus. (Cuvier).

Western Golden-crowned Kinglet (Regulus satrapa olivaceus, Baird).

Abundant throughout the Province.

Ruby-crowned Kinglet (Regulus calendula, Linn).

Abundant thronghout the Province.

Fanily TURDidA. Thrushes, Solitaires and Bluebirds.

Mradestes. (Swainson).

Townsend's Solitaire (Myadestes townsendii, Aud).

Not common. Found east and west of Cascades, including Vancouver Island. 


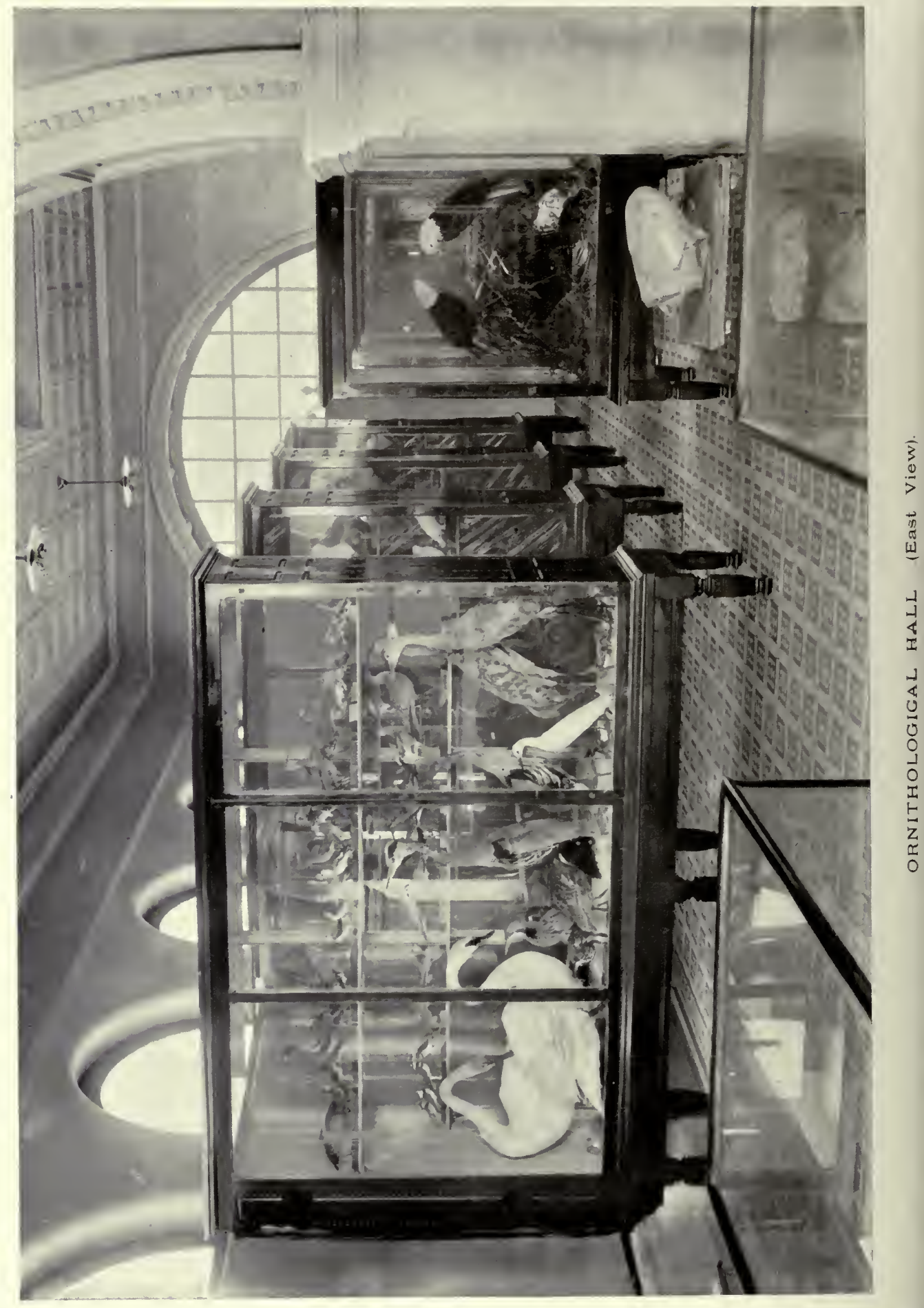




\section{Hylocichla. (Baird).}

Willow Thrush (Hylocichla fusccscens salicicola, Ridgw).

A common summer resident east of Cascades.

Russet-backed Thrush (Hylocichla ustulata, Nutt).

A common resident west of Cascades. Very common on Queen Charlotte Islands.

Olive-backed Thrush (Hylocichla ustulata swainsonii, Cab).

Southern portion of Mainland east of Cascades.

Alaska Hermit Thrush (Hylocichla guttata, Pallas).

West of Cascades, chiefly coastwise. Common at Skidegate, Queen Charlotte Islands.

*Audubon's Hermit Thrush (Hylocichla guttata auduboni, Baird).

Southern portions of the Province, east of Cascaldes to Rocky Mountains.

$$
\text { Merula. (Leach). }
$$

American Robin (Memla migratoria, Linn).

Both forms are to be found on Vancouver Island. Taken at Chilliwhack.

Western Robin (Merule migratoria propinqua, Ridgw).

An abundant resident throughout the Province.

$$
\text { Ixoreus. (Bonaparte). }
$$

Varied Thrush (Ixoreus nevius, Gmel).

Common throughout the Province east and west of Cascades.

$$
\text { Sialia. (Swainson). }
$$

Western Bluebird (Sialia mexicana occidentalis, Towns.

A common summer resident east and west of Cascades. A few winter on Vancouver Island.

Mountain Bluebird (Sialia arctica, Swains).

A summer resident east and west of Cascades, including Vancouver Island.

Notk.-The names with an asterisk (*) before them are the specimens not in the collection of birds or skins, but known to occur in British Columbia. 


\section{BIRD SKINS.}

The study series of skins, numbering over 1,000, and containing a fair representative collection of the birds of the Province, can be seen on application to the Curator, who will be pleased to show them at any time.

\section{GROUPS IN CASES.}

Great Northern Diver (Loon) and young, with Red-winged Blackbird; nest and eggs.

Pied-billed Grebes and nest, with young.

Some of our winter visitants; Chickadees and Kinglets.

Waxwings in wild cherry tree.

Western Red-tailed Hawks fighting over Ruffed Gronse.

Bald Eagles, with young and nest.

Thrushes and Bluebirds in Mountain Ash tree. A winter scene in a Victoria garden.

North-west Coast Herons.

Group representing a section of Bare Island, Straits of Georgia. The birds included are: Tufted Puffins, Pigeon Gnillemots, Glau. cous-winged Gulls and Violet-green Cormorants, that were found nesting on Bare Island during June and July, 1908.

A case containing Albinos, viz.: Meadow Lark from Cornwall, B. C.; Crow, from Vancouver; Crow, from Masset, Queen Charlotte Islands; Crow, from Mayne Island; Crow, from Alberni, Vancouver Island; Crow, from Cache Creek, near Ashcroft; Robin, from Prospect Lake, near Victoria; Western Robin, from Victoria; Robin, from Cache Creek, near Ashcroft; a Loon or Great Northern Diver. from Ucluelet on the West Coast; and a freak Pheasant.

\section{OOLOGY.}

\section{BiRds' EgGs.}

Western Grebe.

American Red-necked Grebe.

Horned Grebe.

Pied-billed Grebe.

Loon.
Macfarlane's Screech Owl. Burrowing Owl.

California Pygmy Owl.

Belted Kingfisher.

Gairdner's Woodpecker. 


\section{Binds' Eggs.-Continued.}

T'ufted P'uflin.

Marbled Murrelet.

Pigeon Guillemot.

California Murre.

Glancous-winged Gull.

American Herring Gull.

Aretic Term.

Leach's Fork-tailed Petrel.

Violet-green Cormorant.

California Brown Pelican.

Mallard.

American Widgeon.

Green-winged Teal.

Canvas-back Duck.

Lesser Scaup Duck.

Ruddy Duck.

Canada Goose.

American Bittern.

Sandhill Crane.

Virginia Rail.

Carolina Rail.

American Coote.

Wilson's Snipe.

Western Sandpiper.

Spotted Sandpiper.

Long-billed Curlew.

Kildeer Plover.

Black Turnstone.

Black Oyster-catclier.

Mountain Partridge.

California Partridge.

Sooty Grouse.

Oregon Ruffed Grouse.

Rock Ptarmigau.

Band-tailed Pigeon.

Momrning Dove.

Turkey Vulture.

Western Red-tailed Hawk.

Swainson's Hawk.
Flickel.

North-western Flicker.

Western Nighthawk.

Rufous Hummingbird.

Kingbird.

Arkansas Kingloird.

Western Wood Pewee.

Western Flycatcher.

American Magpie.

Steller's Jay.

California Crow.

North-west Crow.

San Diego Redwing.

North-western Redwing.

Bullock's Oriole.

Western Meadowlark.

Gambel's Sparrow.

Western Savanna Sparrow.

Nutall's Sparrow.

Western Chipping sparrow.

Oregon Junco.

Rusty Song Sparrow.

Sooty Song Sparrow.

Townsend's Sparrow.

Oregon Towhee Sparrow.

Black-headed Grosbeak.

Louisiana Tanager.

Purple Martin.

Barn Swallow.

Bank Swallow.

Cedar Bird.

Cassin's Vireo.

Orange-crowned Warbler.

Alaskan Yellow Warbler.

Audubon's Warbler.

Catbird.

Vigor's Wren.

Parkman's Wren.

Western Winter Wren. 


\section{Birds' Eggs.-Concluded.}

l'igeon Hawk.

Jirsh Hawk.

American Sparrow Hawk.

American Osprey Hawk.

Golden Eagle.

Bald Eagle.

American Long-eared Owl.

Saw-whet Owl.

Kennicott's Screech Owl.
T'ule Wren.

Red-breasted Nuthatch.

Chestnut-backed Chickadee.

Ruby-crowned Kinglet.

Russet-backed Thrush.

Olive-backed Thrush.

Varied Thrush,*

Western Robin.

Western Bluebird.

\section{REPTILIA.}

Pacific Terrapin, Mud Turtle (Clemm!ys marmorata, B. \& G). Mainland of British Columbia.

Pygmy Horned Toad (Phrynosoma douglasii, Bell). Osoyoos.

Northern Alligator Lizard (Gerhonotus principis, B. \& G). shawnigan and Victoria.

Pacific Rattlesnake (Crotalus lucifer, B. \& G). Carche Creek, Ashcroft, etc. Not found on Vancourer Island.

Desert Gopher Snake (Pituophis catenifer deserticola, Stej). Vernon.

Puget Garter Snake (Thamnophis leptocephala, B. \& G). Hatric, Sicamous, Nelson and Vernon.

Northwestern Garter Snake (Thamnophis parictalis pickeringii, B. \& $\mathrm{G}$ ).

Vancouver Island and Mainland.

Puget Garter Snake (Thammophis leptocepphala, B \& G). Vamcourel Islamd and Mainland.

Wandering Garter Snake (Thammophis vagrans, B. \& G). Victoria.

The Elegant Garter Snake (Thammophis elegans, B. \& G). Nicamous.

Striped Snake (Eutamia vertalis pambalis).

There is also a small collection of Batrachia of British Columbia. 


\section{FISHES.}

\section{ORDER HYPEROTRETI.}

\section{FAMILY HEP'TAREMIDA.}

California Hagfish (Polistotrema stouti, Lockington).

The Hagfish fastens itself on the gills of large fishes, sometimes on the eyes, whence it worlis its way very rapidly into the inside of the body. It then devours all the flesh of the body without breaking the skin, so that the fish is left a mere hulk of head, skin and bones. Vancouver Island.

\section{ORDER HYPEROARTII.}

\section{FAMILY PETROMIZONIDA.}

Marine Lamprey (Entospheuus tridentatus, Gairdner).

Found in the tributaries of the Skeena River.

Brook Lamprey (Lampetia cibaria, Girard).

Cowichan River

\section{ORDER CYCLOSPONDYLI.}

\section{FAMIY SQTALIDE.}

Spiked Dogfish (Squalus sucklii, Girard).

Oak Bay, near Victoria.

\section{ORDER BATOIDEI.}

\section{FAMIL RAJIDAE.}

The Skate (Raja binoculata, Giraud).

'The largest of our Skates, reaching a length of over six feet: the egg-case nearly a foot long. Abundant. Victoria, Race liocks, Vancouver Island. 


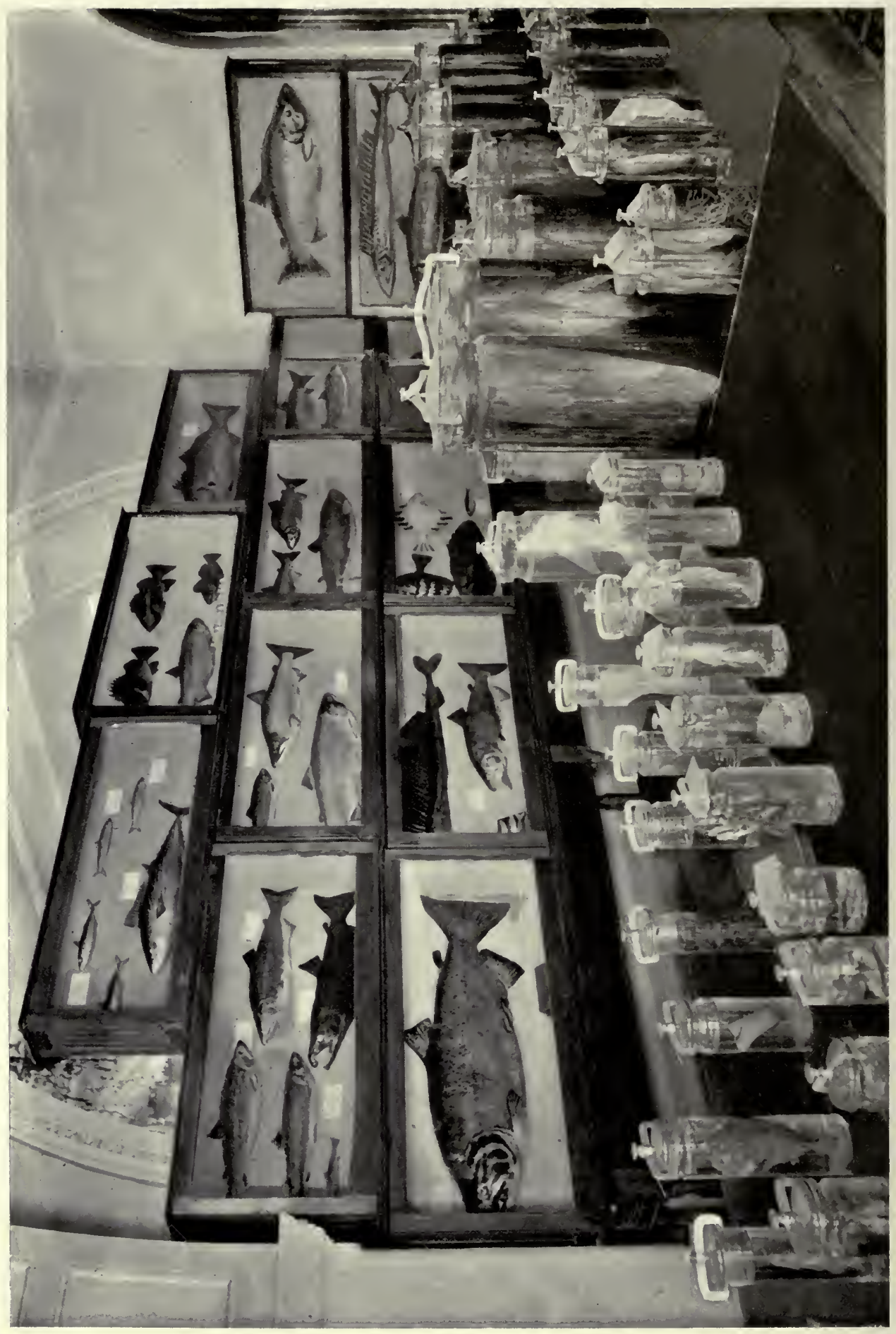

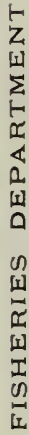




\section{ORDER CHIMAEROIDEI.}

\section{FaMiLY CHIMARIDA.}

Rat Fish (Hydrolugus colliei, Lay \& Bennett).

Very alundant in cold waters at a moderate depth; rarely used as food. Victoria.

\section{ORDER PLECTOSPONDYLI.}

\section{FAMILY CYPRINIDA.}

Chub (Mylocheilus caurinus, Richardson).

Common on Mainland. Taken at Nanaimo on Vancouver Island.

Green's Chub (Couesius greeni, Jordan).

Taken in a small lake near Fort St. James.

Sacramento Pike (Ptychocheilus oregonensis, Richardson).

Richardson's Minnow (Richardsonius lateralis, Girard). Victoria.

\section{ORDER APODES.}

$$
\text { FaMily NEMICHTHYIDA. }
$$

Snipe Eel (Nemichthys avocetta, Jordan \& Gilbert)

Clover Point; Beacon Hill, Victoria.

\section{ORDER ISOSPONDYLI.}

\section{Fanily CLUPEIDA.}

Herring (Clupea pallasii, Cuvier).

Victoria.

California Sardine (Clupanodon ceruleus, Girard).

Alert Bay.

Shad (Alosa sapidissima, Wison). 


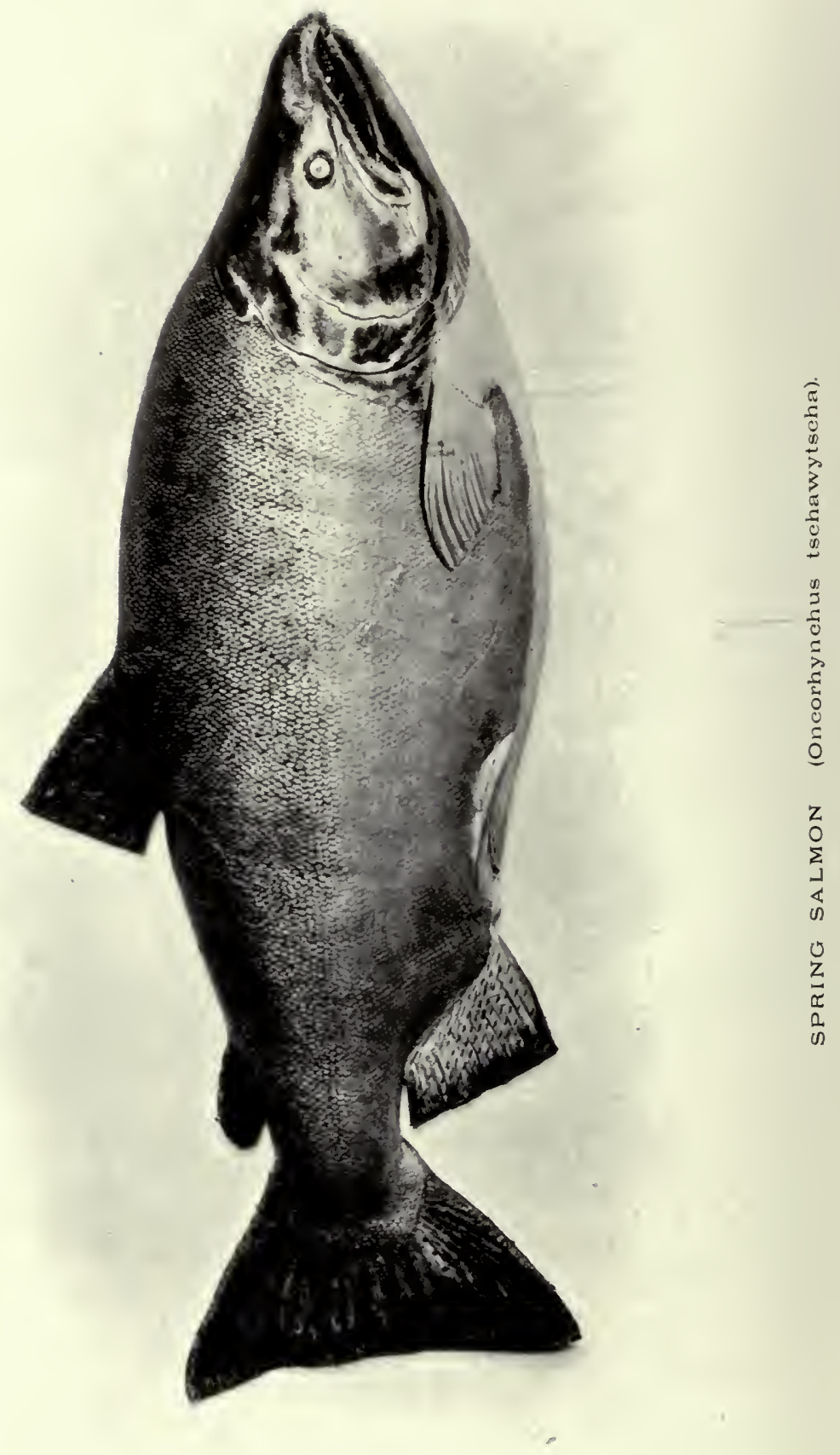




\section{FaMILY ENGRAULIDIDA.}

The Anchovy (Engruulis mordax, Girard).

Extremely abundant in large schools; one of the largest of our Anchovies, and the most valuable as food. Flesh comparatively dark and easily torn, as in a sardine.

\section{FAMILY SALMONIDA.}

River Whitefish (Coreyonns williamsoni, Girard).

From Similkameen River. Common in rivers of the Mainland.

The Humpback Salmon (Oncorhynchus gorbuscho, Walbaum).

The Dog Salmon (Oncorhynchus ketı, Walbaum).

Cowichan.

Spring Salmon (Oncorhynchus tschawytscho, Walbaum).

Vancouver Island. Flesh red and rich in spring, becoming paler as the spawning season approaches; individuals of seventy to one hundred pounds have been taken. They move up the large streams in spring and summer, moving up without feeding, until the spawning season, by which time many of those which started first have travelled more than one thousand miles. It is by far the most valuable of our salmon.

\section{Cohoe Salmon (Oncorhynchus kisutch, Wallbaum).}

Victoria. The Cohoe Salmon are more numerous than the Spring Salmon, and while of smaller size, generally, are just as game. Indeed, nany anglers consider the Cohoe more game than the Spring Salmon. Trolling with rod and line in fresh and salt waters is the favourite method in use amongst anglers for catching Salmon in the Province.

Sockeye Salmon (Oncorhynchus nerka, Walbaum).

Victoria. This Salmon is one of the most graceful of the Salmonida, scarcely inferior to the Spring Salmon when fresh, but the flesh more watery.

Common Trout (Salmo mykiss, Walbaum).

Shawnigan Iake. 

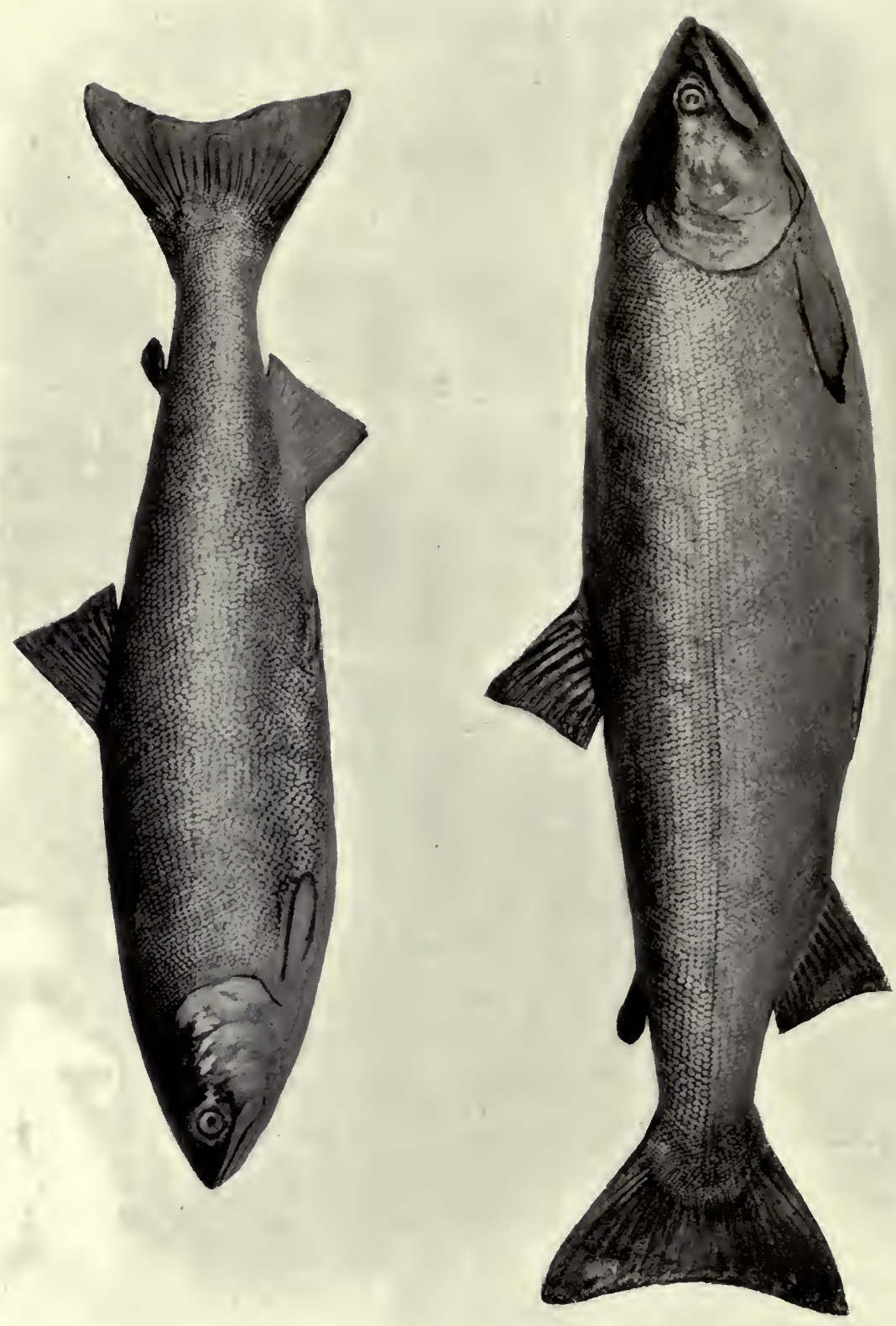

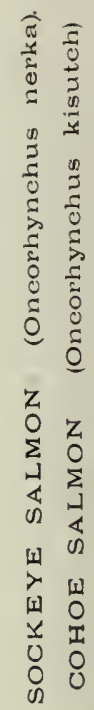


The Steelhead or Gairdner's Trout (Salmo gairdneri, Richardson.

The Steel-head is a large trout abounding in the months of the rivers, reaching the weight of 20 pounds or more, it is migratory like the Salmon and ascending the rivers fully as far; it is similar in quality as food to other trout. Very common in the Kootenay and Okanagan Lakes. As a game fish many anglers consider it the gamest fish taken in these waters. Fraser River and Nanaimo.

Kamloops Trout (Salmo gairdneri lamloops, Jordan).

This is a fine large tront and locally abundant; it is slender and graceful, somewhat different in appearance from the ordinary "Steel-head," but not distinguished by any technical character of any importance. Kootenay Lake.

\section{Great Lake Trout (Cristivomer namaycush, Walbaum).}

This fish reaches a weight of 60 to 100 pounds, averaging about 17. Its name, Namaycush, is an Indian one.

The Charr. Dolly Varden (Salvelinus malma, Walbaum).

This is one of the most beantiful and active of all the Salmonida. It is found in small mountain brooks.

\section{FaMILY ARGENTINIDA.}

The Capelin (Mallotus villosus, Muller).

A delicious little fish, much valued in the far north. The eggs of the Capelin are deposited in sand along Aretic shores in incredible numbers. They are washed up on the beaches, and in about thirty days they are hatched. "The beach then becomes a quivering mass of eggs and sand," from which the little fishes are borne into the sea by the waves. Victoria.

The Oolachan or Candle Fish Thaleichthys pacificus, Richardson).

An excellant pan-fisl, unsurpassed by any fish whatsoever in delicacy of flesh, which is far superior to that of the trout. The flesh is very oily, but the oil has a very attractive flavour. The Indians extract the oil and consider it a great delicacy when mixed with berries. It is sometimes extracted and used as a substitute for 

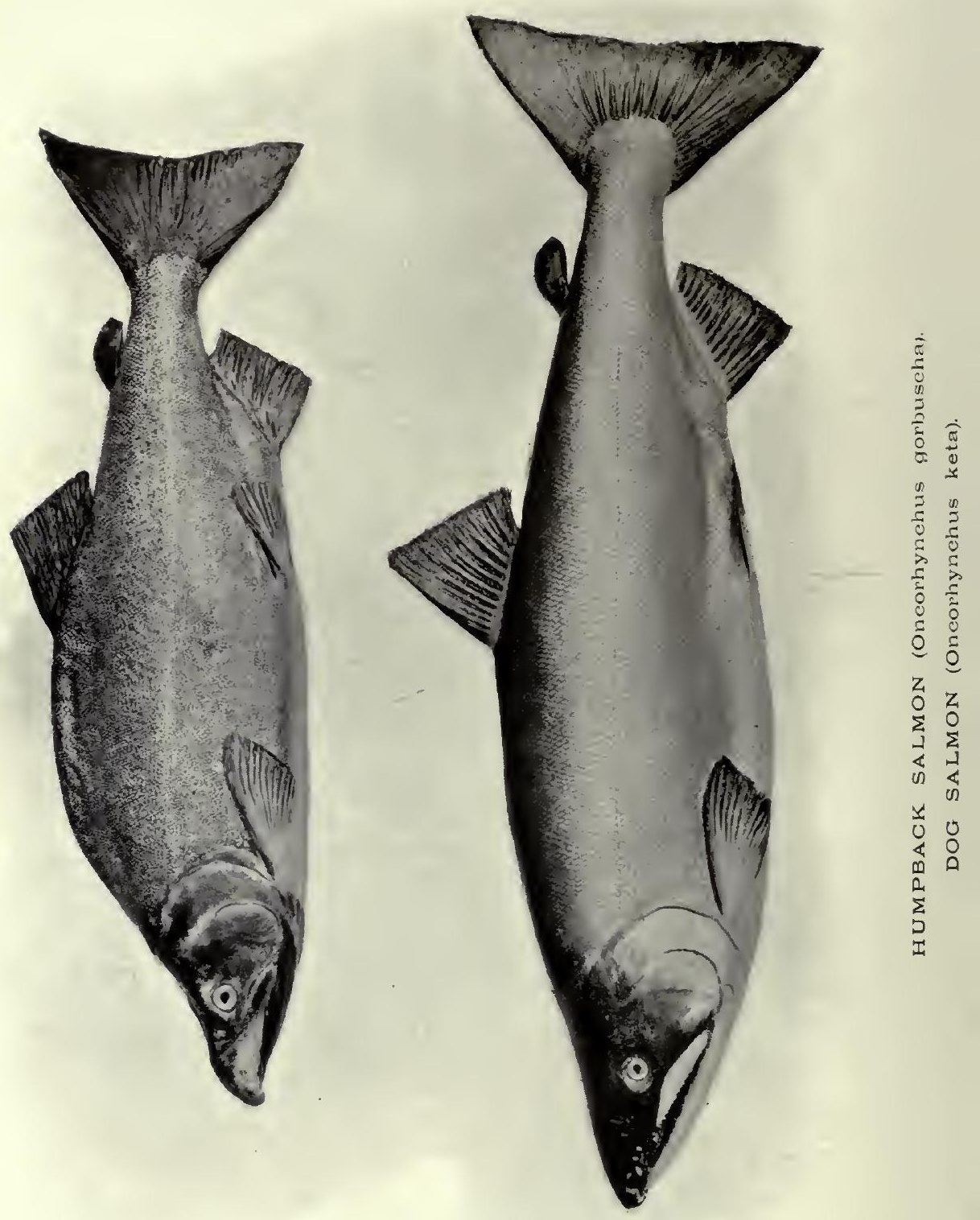
cod-liver oil. It is, however, solid and lard-like at ordinary temperatures. The fishes when dried have been used as candles. In the Fraser River and all rivers to the north of it.

Smelt (Osmerns thalcichthys, Ayres).

A species related to the Oolachan, and of similar flavour as food.

\section{ORDER INIOMI.}

FAMII AIEPISAURIDE.

Hand-saw Fish (Alepisamms borealis, Gill).

Trial Island and Quatsino somnd.

\section{ORDER HEMIBRANCHII.}

FAMILY GASTEROSTEIDA.

California Stickleback (Gasterosteus williamsoni mierocephalus, Girar'd).

Cowichan River.

FAMII AULORHYNCHIDA.

Yellow Stickleback (Aulorhynchus flavidus, Gill).

\section{ORDER LOPHOBRANCHII.}

\section{FAMIL STNGNATHIDA.}

Pipe Fish (Siphostoma griscolincatum, Aỵes).

\section{ORDER ACANTHOPTERI.}

\section{Famig AMMOINTIDA.}

The Sand Launce (Ammodytes personatus, Girard).

An excellent pan-fish; the flesh delicious. It is very abundant; they live in large sclools, burying themselves in the sand near the tide mark. Valued as bait, and useful as food for salmon and other large fishes.

\section{FAMILY KAPRORIDA.}

Prow Fish (Zaprora silenus, Jordan).

Only two specimens known. Taken at Nanaimo and Victoria. The type is in the Provincial Museum. 


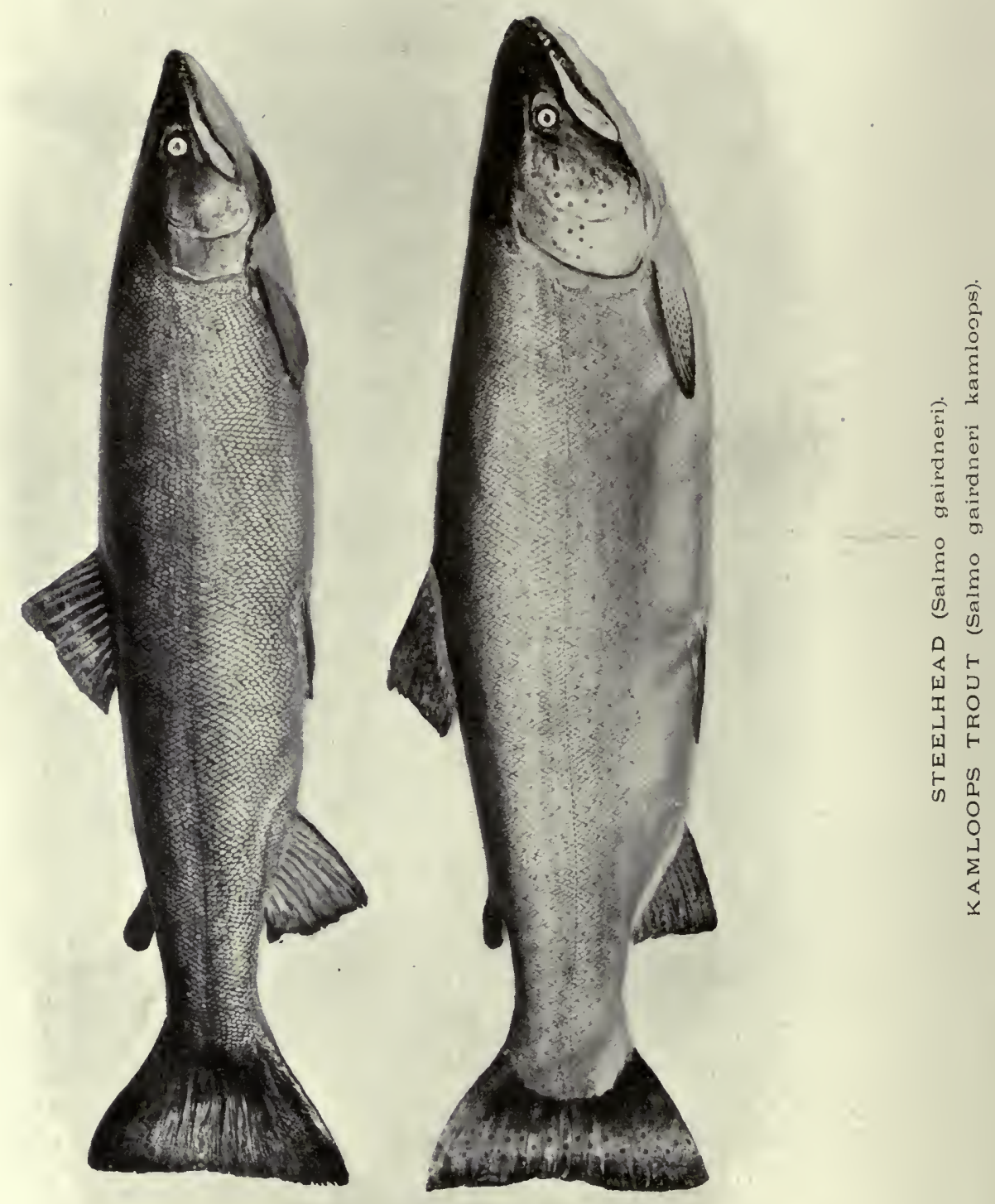


FAMILY TRICHODONTIDA.

The Sandfish (Trichodon stelleri, Cuvier \& Valencienues).

FAMILY HEXAGRAMMIDAE.

Red Rock Trout (Hexagrammos superciliosus, Pallas). Victoria.

Starry Rock Trout (Hexagıammos decagrammus, Pallas).

Victoria.

Blue Cod (Ophiodon elongutus, Giralrd).

Victoria.

Very abundant, reaching a weight of thirty to forty pounds, and one of the most important food fishes on the Coast.

Broad-fin Cod (Zaniolepis lutipinnis, Girrard).

Victoria.

Painted Cod (Oxylebius pietus, Gill).

Victoria. Abundant, but rare in collections, being seldom taken in nets. A most beantiful and active little fish.

\section{FAMIIY ANOPLOPOMATIDA.}

Black Cod or Skil (Anoplopma fimbria, Pallas).

From Cape Flattery to Queen Charlotte Islands.

Family SCORPANIDA.

Jack Fish (Sebastodes puneispinis, Gill).

Black Sea Bass (Sebastodes melanops, Girard).

Victoria.

Red-sea Bass (Sebastodes ruber, Ayres).

Saanich

Striped-sea Bass (Sebastodes nigroeinetus, Ayres).

Saanich and Victoria.

Yellow-backed Rockfish (Sebastodes maliger, Jordan \& Gilbert). Victoria. 


$$
\text { to }
$$


Red Rockfish (Sebustodes ruberrimus, Cramer).

Victoria.

\section{FAMIL SCIANIIDE.}

White Sea Bass (Cynoscion nobilis, Ayres).

Vanconver Island. A most valuable food fish, reaching a weight of eighty pounds; its flesh is firm and rich.

$$
\text { F.MIL STROMATEID.TE. }
$$

California Pompano (Palometa simillima, Ayres).

Victoria.

$$
\text { FAMLY CENTRARCHID.T. }
$$

Small-mouthed Black Bass (Micropterus dolomicu, latcépède).

$$
\text { FAMILY COT'TIDA. }
$$

Cirrus Sculpin (Blepsias eirhosus, P’allas).

Banded Sculpin (Neutichthys oculofasciatus, Gir:ard).

Red Sculpin (Hemilepidotus hemilepidotus, 'Tilesius).

Victoria

Miller's Thumb (Uranidea gulosa, Jordan \& Gilbert). Slıawnigan Isake.

Globe-headed Sculpin (Oligocottus globiceps, Girard) victoria.

\section{'Fanily RHAMPHOCOT'TIDA.}

Richardson's Cottus (Rhamphocottus richardsoni, Gunther). Victoria.

$$
\text { FaMILY AGONID.E. }
$$

Alligator Fish (Podothecus acipenserinus, Tilesius). Victoria.

$$
\text { Famir LIPARIDIJA. }
$$

Stone Sucker (Liparis pulchellus, Ayres).

Green's Sucker (Neoliparis greeni, Jordan). 


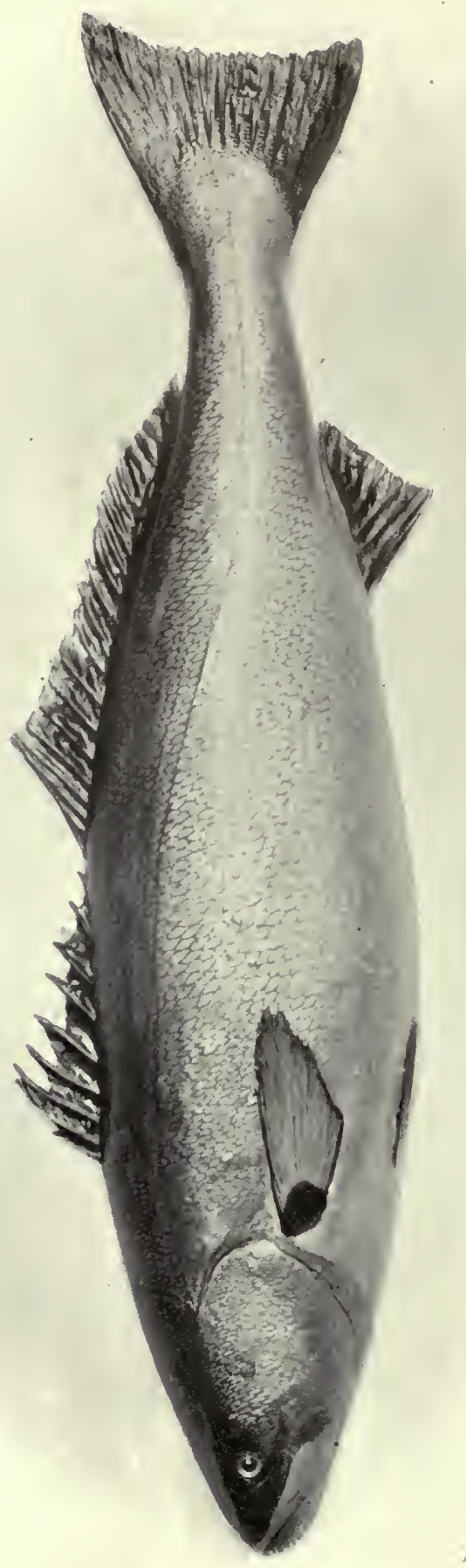

0
0
0
0
0
5
0
0
0
0
0
0
0
0
0
4
0
4
4
0
1
5
5
3
3 


\section{Family CyClopteride.}

Lump Sucker (Cyclopterus spinosus, Muller).

$$
\text { Family BatRaChOIDIDA. }
$$

The Midshipman (Porich thys porosissimus, Culver \& Val).

$$
\text { Family BLENNIIDA. }
$$

The Crested Blenny (Chirolophis polyactocephalus, Jordan \& Gilbert).

Alert Bay.

Ornamented Gunnel (Murwoidcs oruatus, Jordan \& Gilbert).

Yellow Butter Fish (A podichthys flavidus, Girard).

Slimy Butter Fish (Xiphister mucosum, Jordan \& Gilbert).

Snake Blennie (Lumpcnus anguillaris, Pallas).

FAMILY CRYPTACANTHODIDA.

The Wry-mouth (Delolepis virgatus, Bean).

Family ANARHICHADIDA.

The Wolf-eel (Anarrhichthys ocellatus, Ayres).

Victoria. One of our most remarkable fishes. Rarely used as food. Feeds chiefly on Sea-urchins and Sand-dollars.

$$
\text { FAMILY ZOARCIDA. }
$$

The Eelpout (Lycodopsis pacificus, Collett).

$$
\text { Family Gadide. }
$$

The Burbot or Ling (Lota maculosa, Le Seur).

Common in fresh water on the Mainland.

The Cod (Gadus macrocephalus, Tilesius).

Victoria.

Tom Cod (Microgadus proximus, Girard).

Esquimalt.

$$
\text { Fanily MERLUCCIIDA. }
$$

The Hake (Merluccius productus, Ayres). 


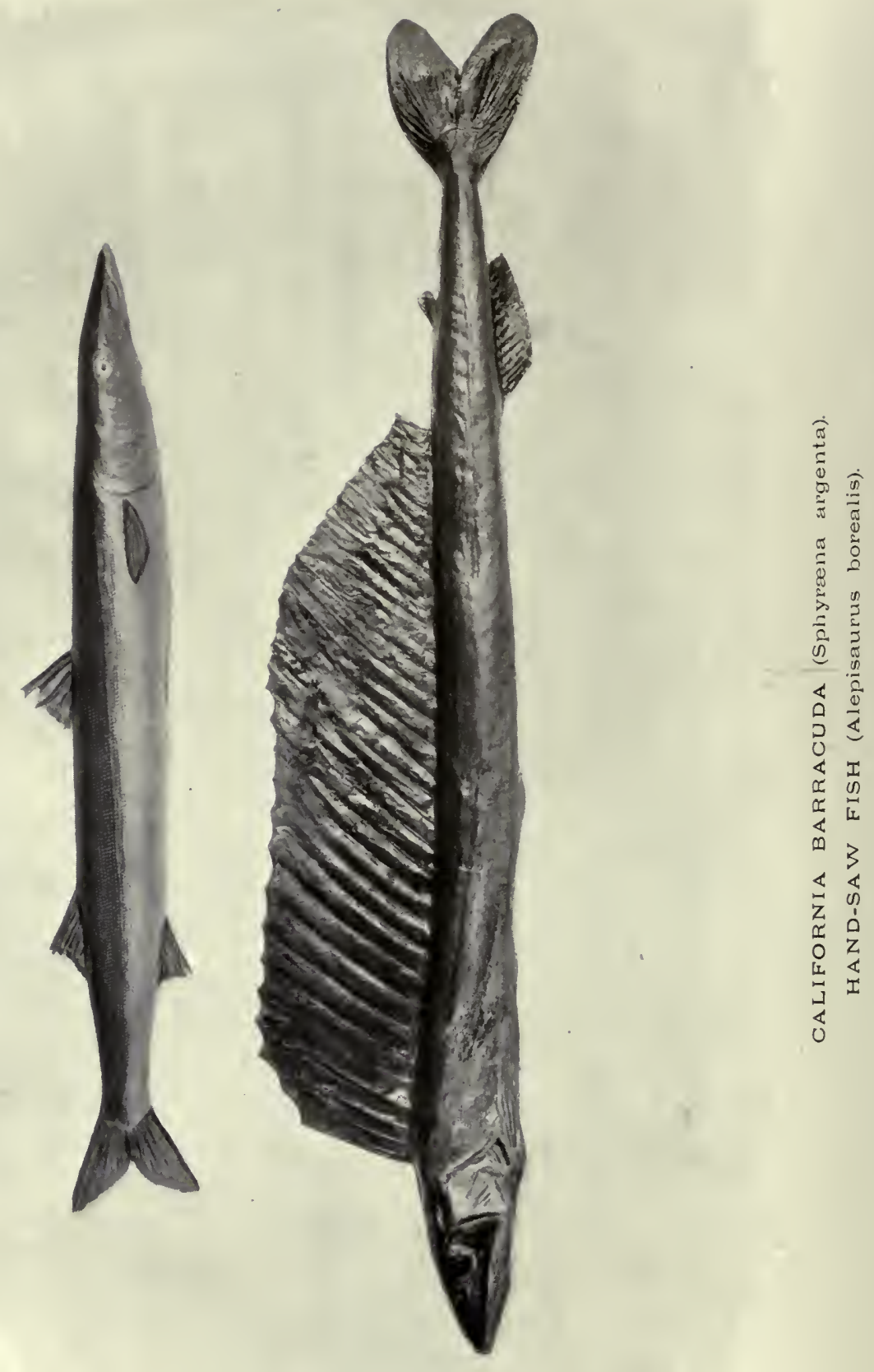




\section{FAMILY SPHYRANIIAE.}

California Barracuda (Sphyrena argentea, Girald).

A long and slendel Barracudda, an important food fish, with flesh roch, film and delicate.

Otter Point, Sooke.

\section{FAMIL SCOMBRIDA.}

Chub Mackerel (Scomba colias, Guelin). Nanaimo.

California Bonito (Surla chilensis, Cuvier \& Valenciennes). Rivers lnlet and Victoria.

\section{ORIDER HE'TEROSOMATA.}

FANILY PLEURONECTIDA.

Arrow-toothed Halibut (Atheresthes stomias, Joldan \& Gilbert). Struits of Georgia.

\section{Halibut (Hippoglossus hippoglossus, Linnaeus).}

Victoria. Largest of the flounders. This genus contains but one species, the well-known Halibut. Abundant on both coasts of the North Atlantic and of the North Pacific. It is found in all northern seas, sonthward in deep water to France. Taken with look and line on all cod banks. Its flesh is pure white and of a delicate flarour, and when smoked forms a tempting morsel at the breakfast table.

The Sharp-nosed Flounder (Pleuronectes vetulus, Jordan \& Gilbert).

The Starry Flounder (Pleuronectes stellatus, Pallas).

Victoria. This is one of the largest flounders, reaching a weight of fifteen to twenty pounds. Of the small-mouthed flounders it is much the largest species known. It is excellent food-fish, and from its size and abundance it is one of the most important of the group in the region where it is found. It lives in shallow water and some. times ascends the largest rivers. It is one of the most widely distributed of all flomders. 
The Sole, so-called (Glyptocephalus zaehirus, Lockington).

This species is a thin, dry flomder reaching a length of some. thing over a foot. It is taken in nets in deep water.

In one of the windows of the Fish Department is shown a seicies of Salmon eggs from the unfertilised egg to the perfect fish. The eggs are from the Harrison Hatchery, B. C. 


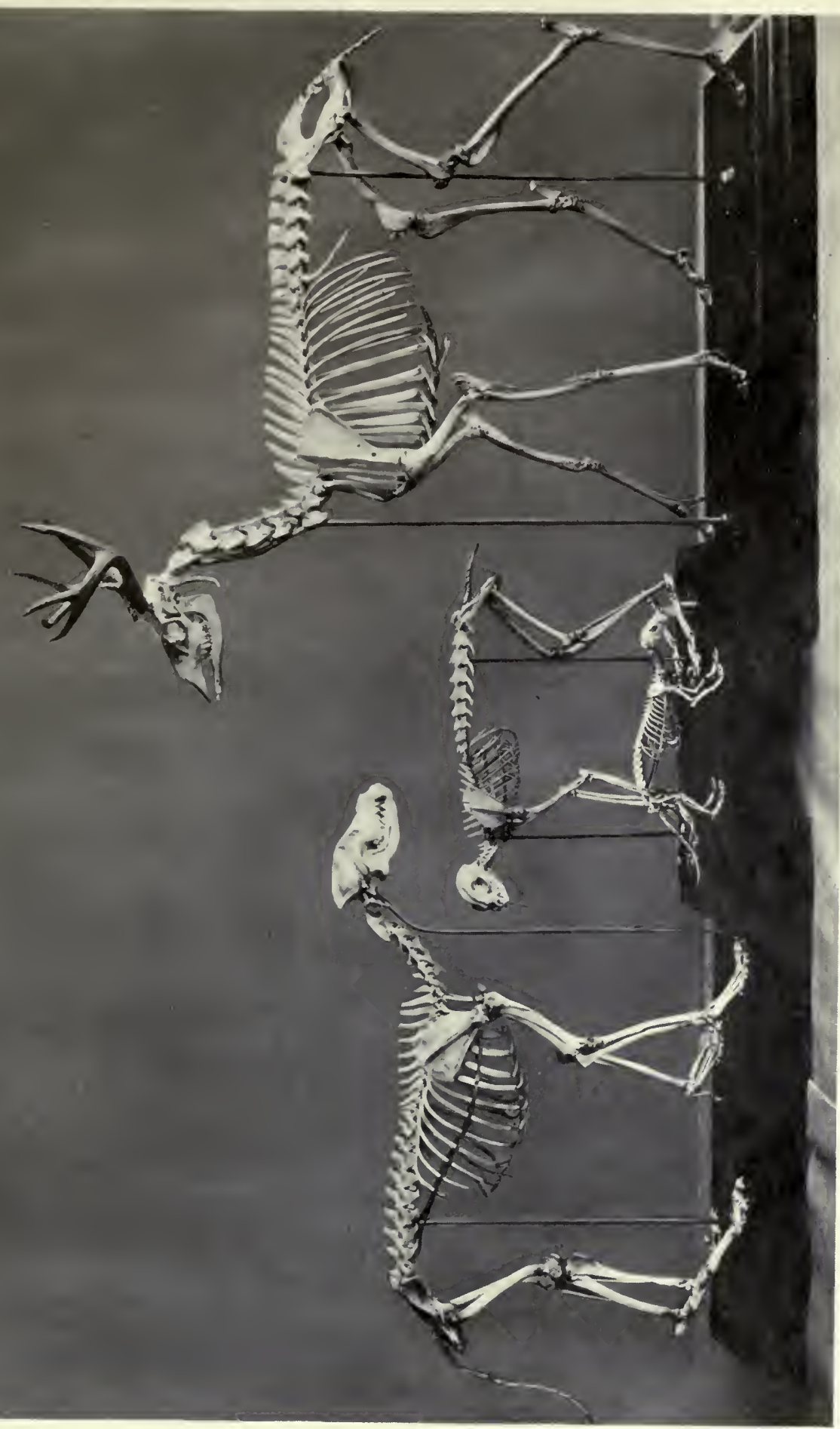

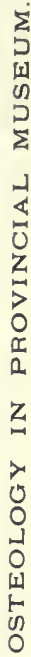




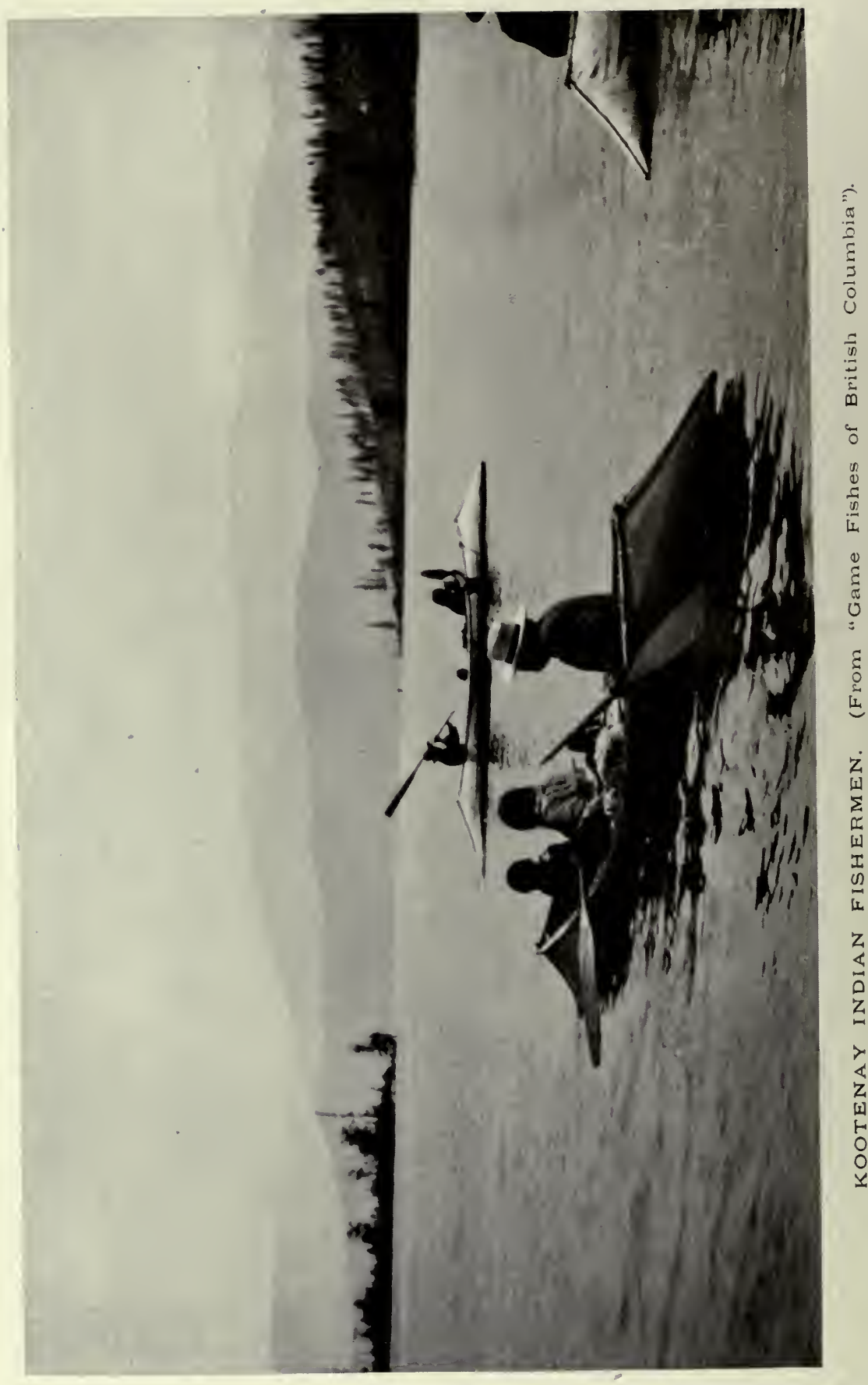




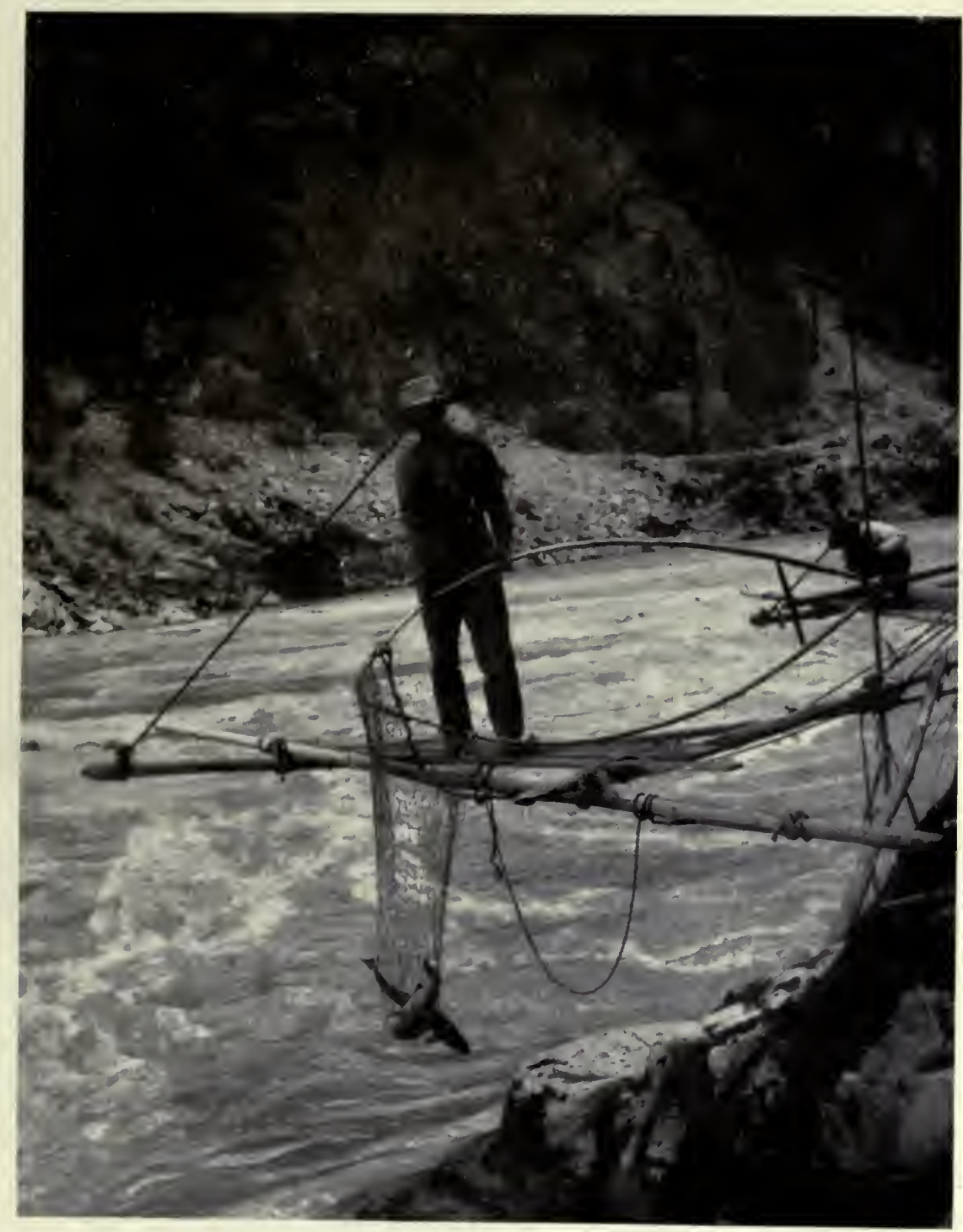

INDIANS CATCHING SALMON IN THE CANYON OF THE FRASER, (From "Game Fishes of British Columbia"). 

THIS BUOK IS DUE ON THE LABT DATE STAMTPED BELOW

AN INITIAL FINE OF 25 CENTS WILL BE ASSESSED FOR FAILURE TO RETURN THIS BOOK ON THE DATE DUE. THE PENALTY WILL INCREASE TO 50 CENTS ON THE FOURTH DAY AND TO $\$ 1.00$ ON THE SEVENTH DAY OVERDUE. 


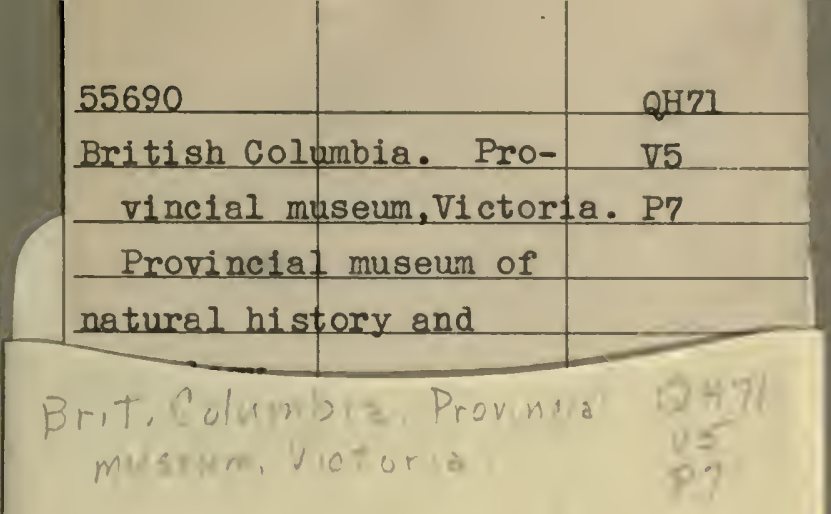



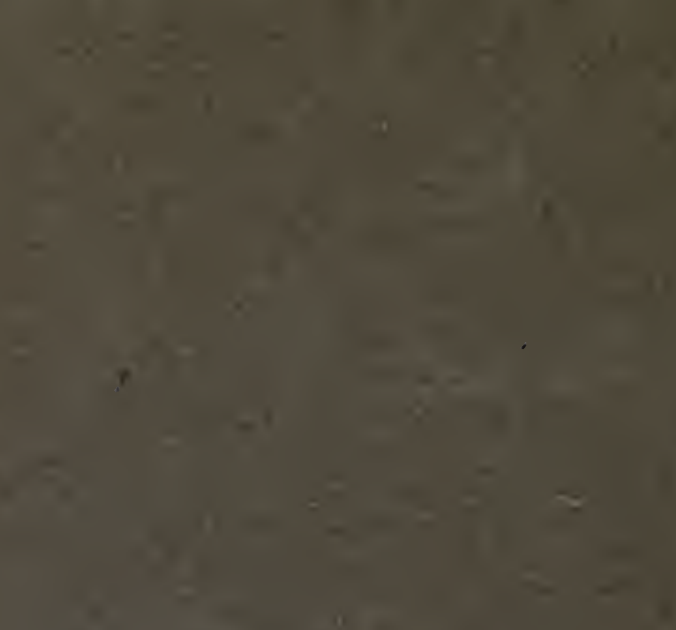

$\frac{-}{2-1}$

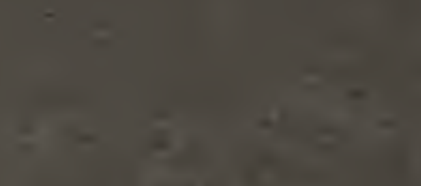

